Nevada

Environmental

Restoration

Project

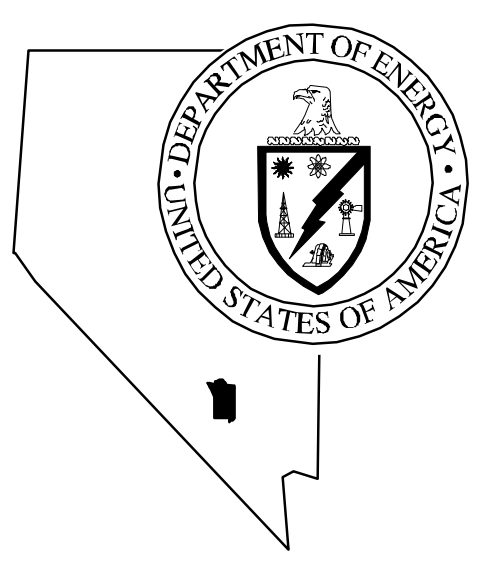

Corrective Action Investigation Plan

for Corrective Action Unit 406: Area 3

Build ing 0 3-7 \& \& B uilding $03-58$

Underground $D$ ischarge $P$ oints and

Corrective Action Unit 42 9: Area 3

Building $03-55$ \& Area 9 Building $09-52$

Underground $D$ ischarge Points,

Tonopah Test Range, N evada

Controlled Copy N $0 .:$

Revision N 0.: 0

M ay 1999

Approved for public release; further dissemination unlimited.

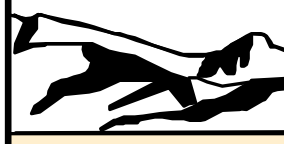

Environm ental Restoration

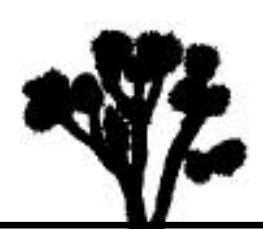

Division 
Available to the public from -
U.S. Department of Commerce
National Technical Information Service
5285 Port Royal Road
Springfield, VA 22161
(703) 487-4650

Available electronically at http://www.doe.gov/bridge. Available to U.S. Department of Energy and its contractors in paper from -

U.S. Department of Energy

Office of Scientific and Technical Information

P.O. Box 62

Oak Ridge, TN 37831-0062

(423) 576-8401

Reference herein to any specific commercial product, process, or service by trade name, trademark, manufacturer, or otherwise, does not necessarily constitute or imply its endorsement, recommendation, or favoring by the United States Government or any agency thereof or its contractors or subcontractors 


\title{
CORRECTIVE ACTION INVESTIGATION PLAN FOR CORRECTIVE ACTION UNIT 406: AREA 3 BUILDING 03-74 \& BUILDING 03-58 UNDERGROUND DISCHARGE POINTS AND CORRECTIVE ACTION UNIT 429: AREA 3 BUILDING 03-55 \& AREA 9 BUILDING 09-52 UNDERGROUND DISCHARGE POINTS, TONOPAH TEST RANGE, NEVADA
}

\author{
DOE Nevada Operations Office \\ Las Vegas, Nevada
}

Controlled Copy No.:

Revision No.: 0

May 1999 


\section{CORRECTIVE ACTION INVESTIGATION PLAN \\ FOR CORRECTIVE ACTION UNIT 406: AREA 3 \\ BUILDING 03-74 \& BUILDING 03-58 \\ UNDERGROUND DISCHARGE POINTS AND \\ CORRECTIVE ACTION UNIT 429: AREA 3 \\ BUILDING 03-55 \& AREA 9 BUILDING 09-52 \\ UNDERGROUND DISCHARGE POINTS, TONOPAH TEST RANGE, NEVADA}

Approved by:

Signature Approved

Date:

Janet Appenzeller-Wing, Project Manager

Industrial Sites Project

Approved by:

Signature Approved

Date:

$5 / 20 / 99$

Runore C. Wycoff, Division Director

Environmental Restoration Division 


\section{Table of Contents}

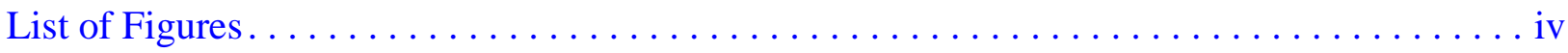

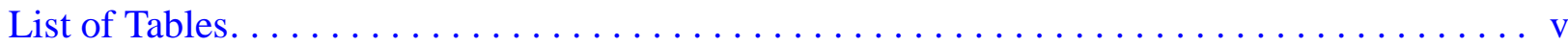

List of Acronyms and Abbreviations $\ldots \ldots \ldots \ldots \ldots \ldots \ldots \ldots \ldots \ldots \ldots \ldots \ldots . \ldots \ldots$

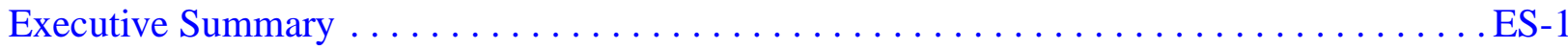

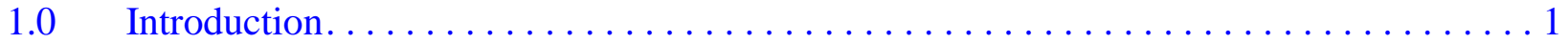

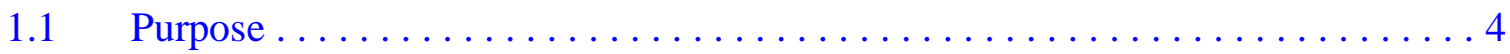

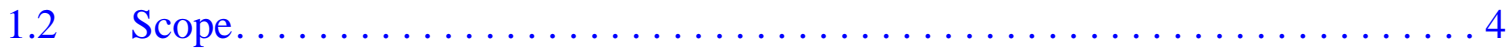

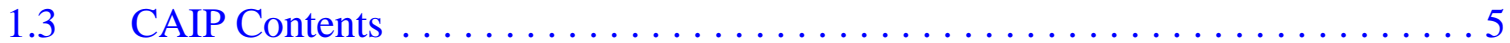

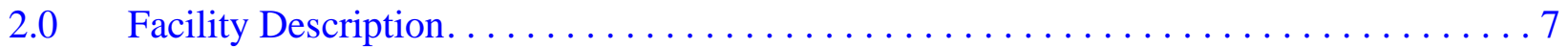

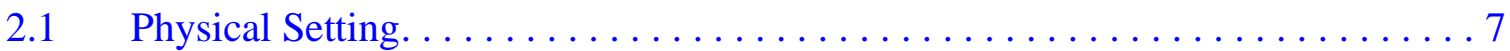

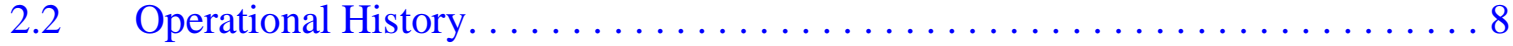

2.2.1 Area 3 Heavy Duty Shop UDP...................... 8

2.2.2 Area 3 Uninterrupted Power Supply Building UDPs........... 11

2.2.3 Area 3 Photoshop UDPs.......................... 12

2.2.4 Area 9 Mobile Photographic Laboratory UDPs ................ 13

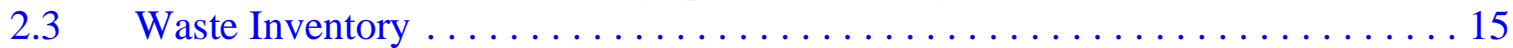

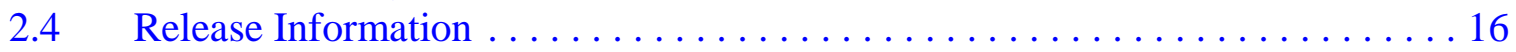

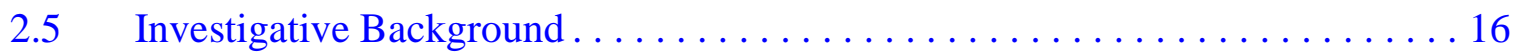

$3.0 \quad$ Objectives ............................................ 19

$3.1 \quad$ Conceptual Site Model .................................. 19

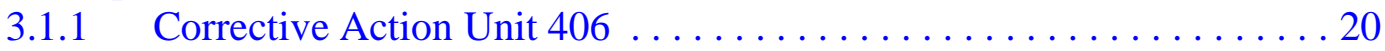

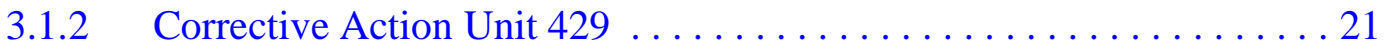

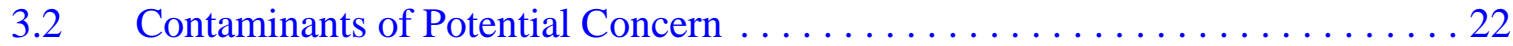

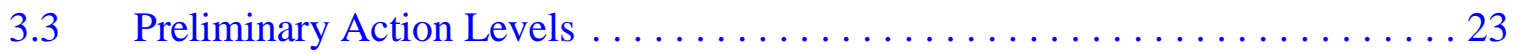

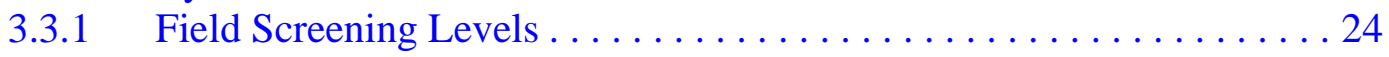

3.3.2 Chemical Preliminary Action Levels .................... 24

3.3.3 Radiological Preliminary Action Levels . . . . . . . . . . . . . . . . 25

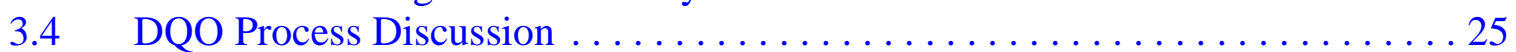

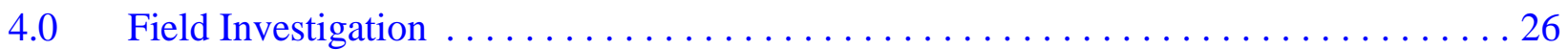

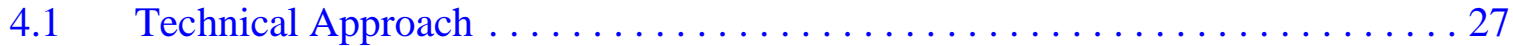

$4.2 \quad$ Field Activities . . . . . . . . . . . . . . . . . . . . . . . . . . . . . 28

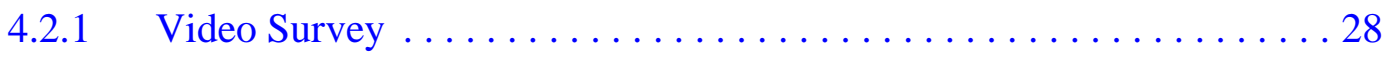

4.2.2 Excavation Activities ............................. 29

4.2.3 Direct-Push Methods .................................. 29

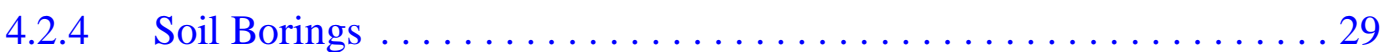

4.2.5 Field Screening. . . . . . . . . . . . . . . . . . . . . . . . 30 


\section{Table of Contents (Continued)}

$4.3 \quad$ Investigation Strategy for CAUs 406 and $429 \ldots \ldots \ldots \ldots \ldots \ldots \ldots \ldots$

4.3.1 CAU 406, Heavy Duty Shop UDP, CAS 03-51-002-0374 . . . . . . . . 31

4.3.2 CAU 406, UPS UDP, CAS 03-51-003-0358 . . . . . . . . . . . 33

4.3.3 CAU 429, Area 3 Photoshop UDPs, CAS 03-51-001-0355 . . . . . . . 35

4.3.4 CAU 429, Area 9 Mobile Photo Lab UDPs, CAS 09-51-001-0952 . . . 37

4.4 Sampling Criteria . . . . . . . . . . . . . . . . . . . . 39

4.4.1 Environmental Samples . . . . . . . . . . . . . . . . . . . . . 39

4.4 .2 Quality Control Samples. . . . . . . . . . . . . . . . . . . 40

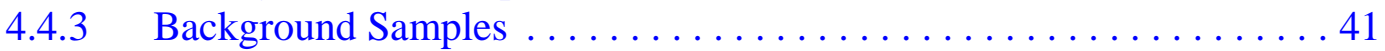

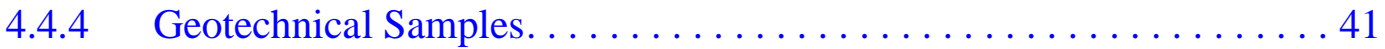

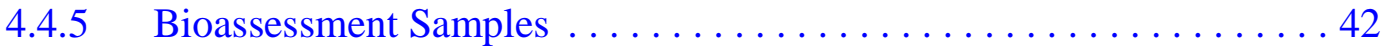

$5.0 \quad$ Waste Management. . . . . . . . . . . . . . . . . . . . 43

$5.1 \quad$ Waste Minimization . . . . . . . . . . . . . . . . . . . . 44

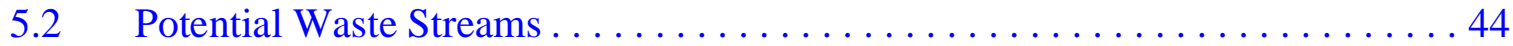

5.3 Investigation-Derived Waste Management $\ldots \ldots \ldots \ldots \ldots \ldots \ldots \ldots \ldots$

5.3 .1 Sanitary Wastes . . . . . . . . . . . . . . . . . . 45

5.3 .2 Low-Level Radioactive Waste . . . . . . . . . . . . . . . . 45

5.3 .3 Hydrocarbon. . . . . . . . . . . . . . . . . . . 46

5.3 .4 Hazardous Waste . . . . . . . . . . . . . . . . . . 46

5.3.5 Mixed Wastes............................ 47

$6.0 \quad$ Duration and Records Availability . . . . . . . . . . . . . . . . . . . . 49

$6.1 \quad$ Duration . . . . . . . . . . . . . . . . . . . . . . 49

6.2 Records Availability . . . . . . . . . . . . . . . . . . . 49

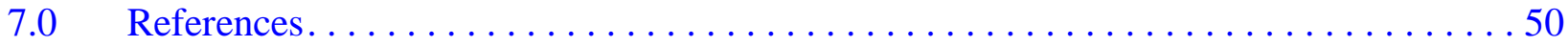

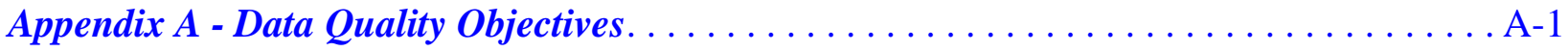

A.1.0 Introduction. . . . . . . . . . . .

A.1.1 Problem Statement . . . . . . . . . . . . . . . . . . . . . . . A-2

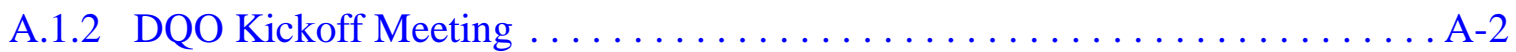

A.2.0 Conceptual Model. . . . . . . . . . . . . . . . . . . . . . . A-4

A.3.0 Potential Contaminants . . . . . . . . . . . . . . . . . . . . . . A-8

A.4.0 Decisions and Inputs. . . . . . . . . . . . . . . . . . . . . A-12

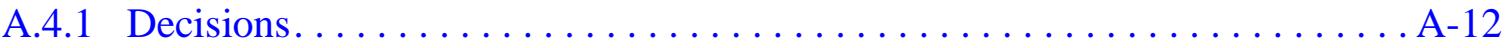

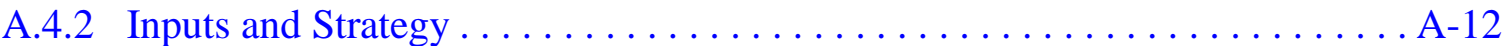




\section{Table of Contents (Continued)}

A.5.0 Investigation Strategy $\ldots \ldots \ldots \ldots \ldots \ldots \ldots \ldots \ldots \ldots \ldots \ldots \ldots \ldots$ A $\ldots \ldots \ldots$

A.5.1 Heavy Duty Maintenance Shop UDP . . . . . . . . . . . . . . . . . . . A-15

A.5.2 Uninterrupted Power Supply Building UDPs. . . . . . . . . . . . A-16

A.5.3 Area 3 Photoshop UDPs . . . . . . . . . . . . . . . . . . A-16

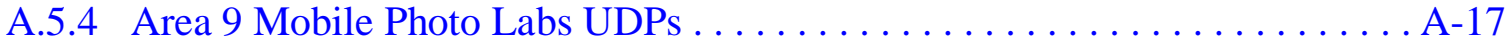

A.6.0 Decision Rules . . . . . . . . . . . . . . . . . . . . . . . . A-18

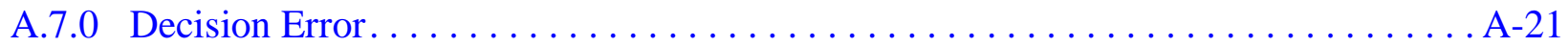

A.8.0 References.................................. A-22

Appendix B - Project Organization . . . . . . . . . . . . .

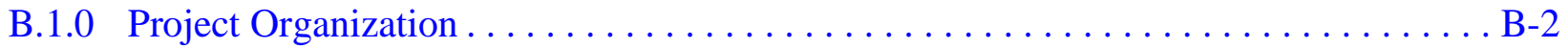

Appendix C - Laboratory Chemical, Toxicity Characteristic Leaching Procedure, and Radiochemistry Analytical Requirements for Industrial Sites . . . . . . . . . . . . C-1

C.1.0 References...............................

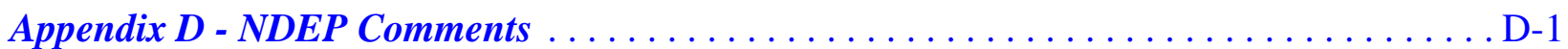




\section{List of Figures}

Number

1-1 Tonopah Test Range Location Map ......................... 2

1-2 Location of Area $3 \&$ Area 9, Tonopah Test Range................... 3

2-1 Cross-Sectional View of a Typical UDP Configuration. . . . . . . . . . . 9

2-2 Approximate Location of Heavy Duty Shop UDP, UPS Building UDPs, and Area 3 Photoshop UDPs in Area 3, TTR ..................... 10

2-3 Approximate Location of Mobile Photographic Lab UDPs, Area 9, Tonopah Test Range .............................. 14

4-1 Proposed Trenching and Sampling Locations for the Heavy Duty Shop UDPs . . . 32

4-2 Proposed Trenching Locations for the UPS Building UDPs . ............ 34

4-3 Proposed Trenching and Sampling Locations for the Area 3 Photoshop UDPs ... 36

4-4 Proposed Investigation Areas, Mobile Photoprocessing Lab UDPs Area 9, Tonopah Test Range ............................. 38 


\section{List of Tables}

Number

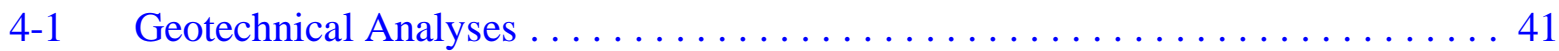

A.1-1 DQO Kickoff Meeting Participants $\ldots \ldots \ldots \ldots \ldots \ldots \ldots \ldots \ldots \ldots \ldots \ldots$

A.2-1 Conceptual Site Model $\ldots \ldots \ldots \ldots \ldots \ldots \ldots \ldots \ldots \ldots \ldots \ldots \ldots \ldots$

A.3-1 CAU 406 Contaminants of Potential Concern (Heavy Duty Shop, CAS 03-51-002-0374) . . . . . . . . . . . . . . . . A-9

A.3-2 CAU 406 Contaminants of Potential Concern

(Uninterrupted Power Supply Building, CAS 03-51-003-0358) . . . . . . . . . A-10

A.3-3 CAU 429 Contaminants of Potential Concern . . . . . . . . . . . . . . . . . . A-11

A.4-1 Decisions, Inputs, and General Strategies $\ldots \ldots \ldots \ldots \ldots \ldots \ldots \ldots \ldots$ A-13

A.6-1 CAS-Specific Decision Points and Rules.................... A-19 


\section{List of Acronyms and Abbreviations}

ALARA As low as reasonably achievable

bgs Below ground surface

BN Bechtel Nevada

CADD Corrective Action Decision Document

CAIP Corrective Action Investigation Plan

CAS Corrective Action Site(s)

CAU Corrective Action Unit

CFR Code of Federal Regulations

$\mathrm{cm} \quad$ Centimeter(s)

COPC Contaminant(s) of potential concern

DOE U.S. Department of Energy

DOE/NV U.S. Department of Energy, Nevada Operations Office

DOT U.S. Department of Transportation

DQO Data Quality Objective(s)

EPA U.S. Environmental Protection Agency

DU Depleted uranium

EPA U.S. Environmental Protection Agency

FFACO Federal Facility Agreement and Consent Order

$\mathrm{ft} \quad$ Foot (feet)

gal Gallon(s)

HASP Health and Safety Plan

HWAA Hazardous waste accumulation area

IDW Investigation-derived waste

in. $\quad \operatorname{Inch}(\mathrm{es})$

IT IT Corporation

$\mathrm{km} \quad$ Kilometer(s) 


\title{
List of Acronyms and Abbreviations (Continued)
}

\author{
L Liter(s) \\ LLW Low-level radioactive waste \\ m Meter(s) \\ mi Mile(s) \\ $\mathrm{mg} / \mathrm{kg} \quad$ Milligram(s) per kilogram \\ $\mathrm{mg} / \mathrm{L} \quad$ Milligram(s) per liter \\ MARSSIM Multi-Agency Radiation Survey and Site Investigation Manual \\ MS/MSD Matrix Spike/matrix spike duplicate \\ NAC Nevada Administrative Code \\ NaI Sodium Iodide \\ NDEP Nevada Division of Environmental Protection \\ NEPA National Environmental Policy Act \\ NRC U.S. Nuclear Regulatory Commission \\ NRS Nevada Revised Statutes \\ NTSWAC Nevada Test Site Waste Acceptance Criteria \\ PAL Preliminary action levels \\ PCB Polychlorinated biphenyl(s) \\ pCi/L Picocurie(s) per liter \\ PPE Personal protective equipment \\ ppm Part(s) per million \\ PRG Preliminary Remediation Goal(s) \\ QA/QC Quality assurance/quality control \\ QAPP Quality Assurance Project Plan \\ QC Quality control \\ RCRA Resource Conservation and Recovery Act \\ SNL Sandia National Laboratories
}




\section{List of Acronyms and Abbreviations (Continued)}

SSHASP Site-specific health and safety plan

SVOC Semivolatile organic compound(s)

TCLP Toxicity Characteristic Leaching Procedure

TID Tamper-indicating device(s)

TPH Total petroleum hydrocarbon(s)

TTR Tonopah Test Range

VOC Volatile organic compound(s)

UDP Underground discharge point

UPS Uninterrupted power supply

XRF X-ray fluorescence 


\section{Executive Summary}

The Corrective Action Investigation Plan for Corrective Action Unit 406, Areas 3, 9 Buildings 03-74 \& UPS Underground Discharge Points and Corrective Action Unit 429, Areas 3, 9 Photoprocessing Underground Discharge Points, has been developed in accordance with the Federal Facility Agreement and Consent Order agreed to by the U.S. Department of Energy, Nevada Operations Office; the State of Nevada Division of Environmental Protection; and the U.S. Department of Defense. Corrective Action Unit 406 consists of two Corrective Action Sites: 03-51-002-0374, known as the Heavy Duty Shop Underground Discharge Point Sumps, and 03-51-003-0358, UPS Building Underground Discharge Point. Corrective Action Unit 429 also consists of two Corrective Action Sites: 03-51-001-0355, the Photo Shop Underground Discharge Point Drains, and 09-51-001-0952, Mobile Photographic Lab Underground Discharge Points.

Before the early 1990s, underground discharge points were used to dispose of effluent related to maintenance and photographic operations at the Tonopah Test Range. The underground discharge points are typically subgrade shallow dry wells or excavations filled with gravel. Effluent was discharged to the underground discharge points through drainage pipes and then allowed to percolate into the surrounding soil. Soils surrounding the underground discharge points have likely been impacted by wastewater containing chemicals associated with equipment maintenance operations (e.g., hydrocarbons or solvents) or photoprocessing operations (i.e., silver).

Based on site history collected to support the Data Quality Objectives process, contaminants of potential concern for Corrective Action Unit 406 are total petroleum hydrocarbons, volatile organic compounds, semivolatile organic compounds, polychlorinated biphenyls, and heavy metals. The contaminants of potential concern for Corrective Action Unit 429 are volatile organic compounds, semivolatile organic compounds, and Resource Conservation and Recovery Act metals. The generalized conceptual site model for both Corrective Action Units 406 and 429 is as follows:

- The volume and concentrations of the contaminants of potential concern are unknown but contamination is expected to be concentrated at the base of the underground discharge points, if present.

- Contaminants of potential concern, primarily in liquid form, were released to the underground discharge points. The effluent was mainly water with low concentrations of contaminants. 
- The underground discharge points are no longer in service; however, Building 09-52 septic system is functional but abandoned.

- Contamination is not expected to extend laterally beyond 10 times the width of the underground discharge point.

- Vertical contamination is not expected to exceed three times the vertical dimension of the underground discharge point below the underground discharge point base. Migration is primarily gravity controlled, but geologic control at depth may influence or limit contaminant migration.

- Relatively low contaminant concentrations and volume, low mobility of constituents, and a lack of a driving force will limit the subsurface lateral and vertical migration of contaminants of potential concern.

- Arid climate limits infiltration, while high evapotranspiration rates restrict the mobility of contaminants of potential concern.

- Nearby utilities and buildings, adverse weather conditions, restricted access, and range activities may create practical and/or physical constraints to the field investigation.

- Potential exposures to personnel would be oral ingestion, inhalation, or dermal contact of contaminants of potential concern in the soil during subsurface investigation activities.

A more detailed conceptual site model is presented in Section 3.0 of the investigation plan. The conceptual site model serves as the basis for the sampling strategy.

The technical approach for investigating this Corrective Action Unit consists of the following activities:

- Perform video surveys to determine location and condition of discharge pipes.

- Determine the locations of the underground discharge points using video surveys, utility location devices, and excavation, as necessary.

- Collect surface and near-surface samples using direct-push techniques at underground discharge point locations that may have discharged to the ground surface.

- Drill boreholes using a hollow-stem auger or other suitable method capable of reaching the expected vertical extent of contaminants of potential concern, penetrating potential leach rock materials (e.g., concrete or gravel) and providing suitable core for sample collection and logging of subsurface conditions. 
- Conduct field screening to direct drilling and sampling activities and provide an initial assessment of surface and subsurface impact.

- Collect subsurface soil samples for field screening, laboratory analysis, and geotechnical and biological parameter analysis, as necessary.

- Log core to assess soil characteristics.

Field-screening methods will be used to compare concentrations to field screening levels of volatile organics, radioactivity, hydrocarbons, and silver. Samples will be collected for laboratory analysis from each site. Additional sampling and analytical details are presented in Section 4.0 of the Corrective Action Investigation Plan. Details of the waste management strategy for the Corrective Action Units are included in Section 5.0 of the investigation plan.

Under the Federal Facility Agreement and Consent Order, the Corrective Action Investigation Plan will be submitted to the Nevada Division of Environmental Protection for approval. Field work will be conducted following approval of the plan. The results of the field investigation will support a defensible evaluation of corrective action alternatives in the Corrective Action Decision Document. 


\subsection{Introduction}

This Corrective Action Investigation Plan (CAIP) has been developed in accordance with the Federal Facility Agreement and Consent Order (FFACO) that was agreed to by the U.S. Department of Energy, Nevada Operations Office (DOE/NV); the State of Nevada Division of Environmental Protection (NDEP); and the U.S. Department of Defense (FFACO, 1996). The CAIP is a document that provides or references all of the specific information for investigation activities associated with Corrective Action Units (CAUs) or Corrective Action Sites (CASs). According to the FFACO (1996), CASs are sites potentially requiring corrective action(s) and may include solid waste management units or individual disposal or release sites. Corrective Action Units consist of one or more CASs grouped together based on geography, technical similarity, or agency responsibility for the purpose of determining corrective actions.

This CAIP contains the environmental sample collection objectives and the criteria for conducting site investigation activities at the Underground Discharge Points (UDPs) included in both CAU 406 and CAU 429. The CAUs are located in Area 3 and Area 9 of the Tonopah Test Range (TTR). The TTR, included in the Nellis Air Force Range, is approximately 255 kilometers (km) (140 miles [mi]) northwest of Las Vegas, Nevada (Figure 1-1).

Corrective Action Unit 406 is comprised of the Area 3 Heavy Duty Shop (Building 03-74) UDP (CAS 03-51-002-0374) and the Area 3 Uninterrupted Power Supply (UPS) Building UDPs (CAS 03-51-003-0358). Corrective Action Unit 429 is comprised of the Area 3 Photo Shop UDPs (CAS 03-51-001-0355) and the Area 9 Mobile Photographic Lab UDPs (CAS 09-51-001-0952) (Figure 1-2).

Before the early 1990s, UDPs were used to dispose of effluent related to maintenance and photographic operations at the TTR. The UDPs are typically subgrade shallow dry wells or excavations filled with gravel. Effluent was discharged to the UDPs through drainage pipes and then allowed to percolate into the surrounding soil. Soils surrounding the UDPs have likely been impacted by wastewater containing chemicals associated with the Heavy Duty Shop (e.g., hydrocarbons or solvents) and/or associated with photoprocessing operations (e.g., silver). 


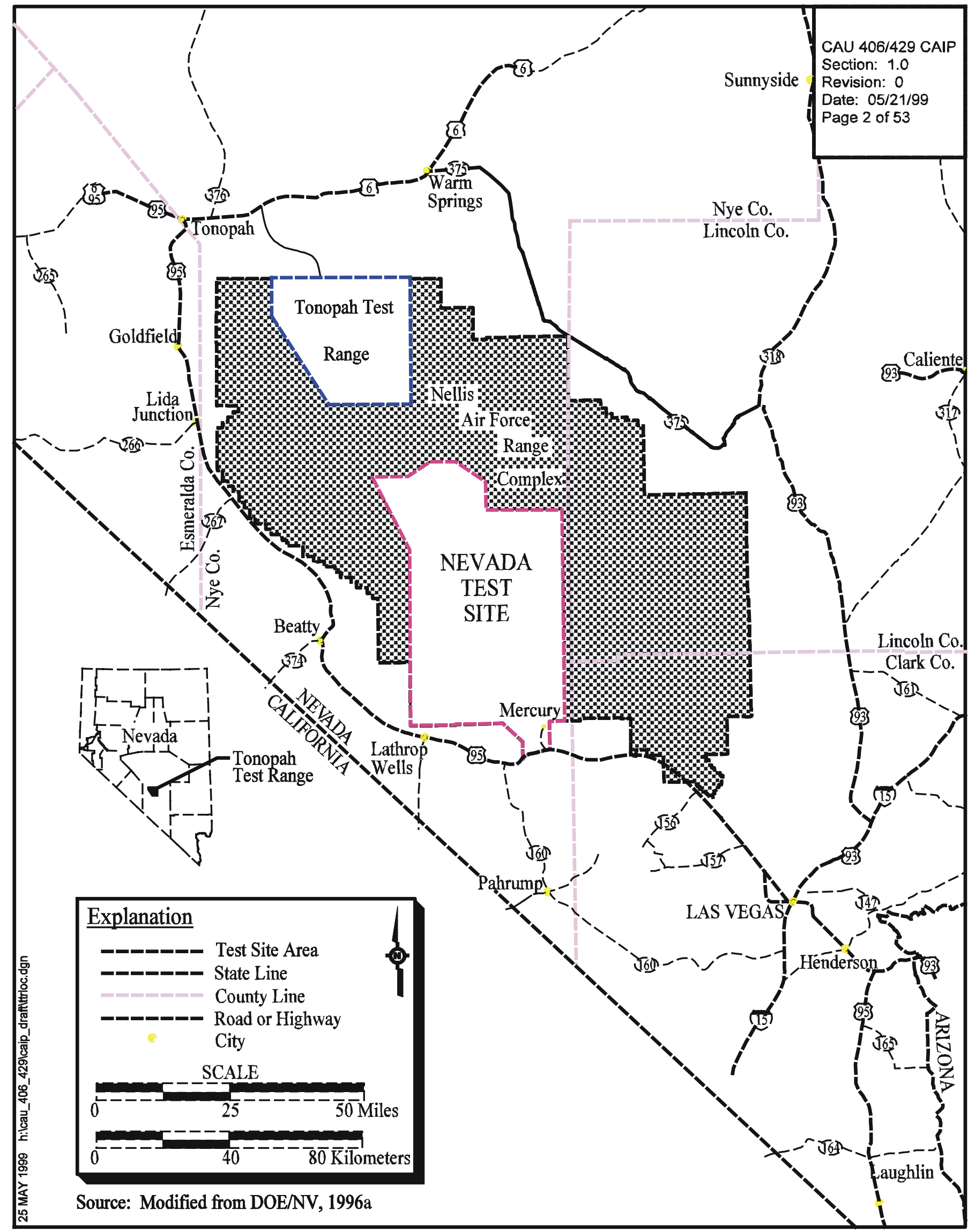

Figure 1-1

Tonopah Test Range Location Map 


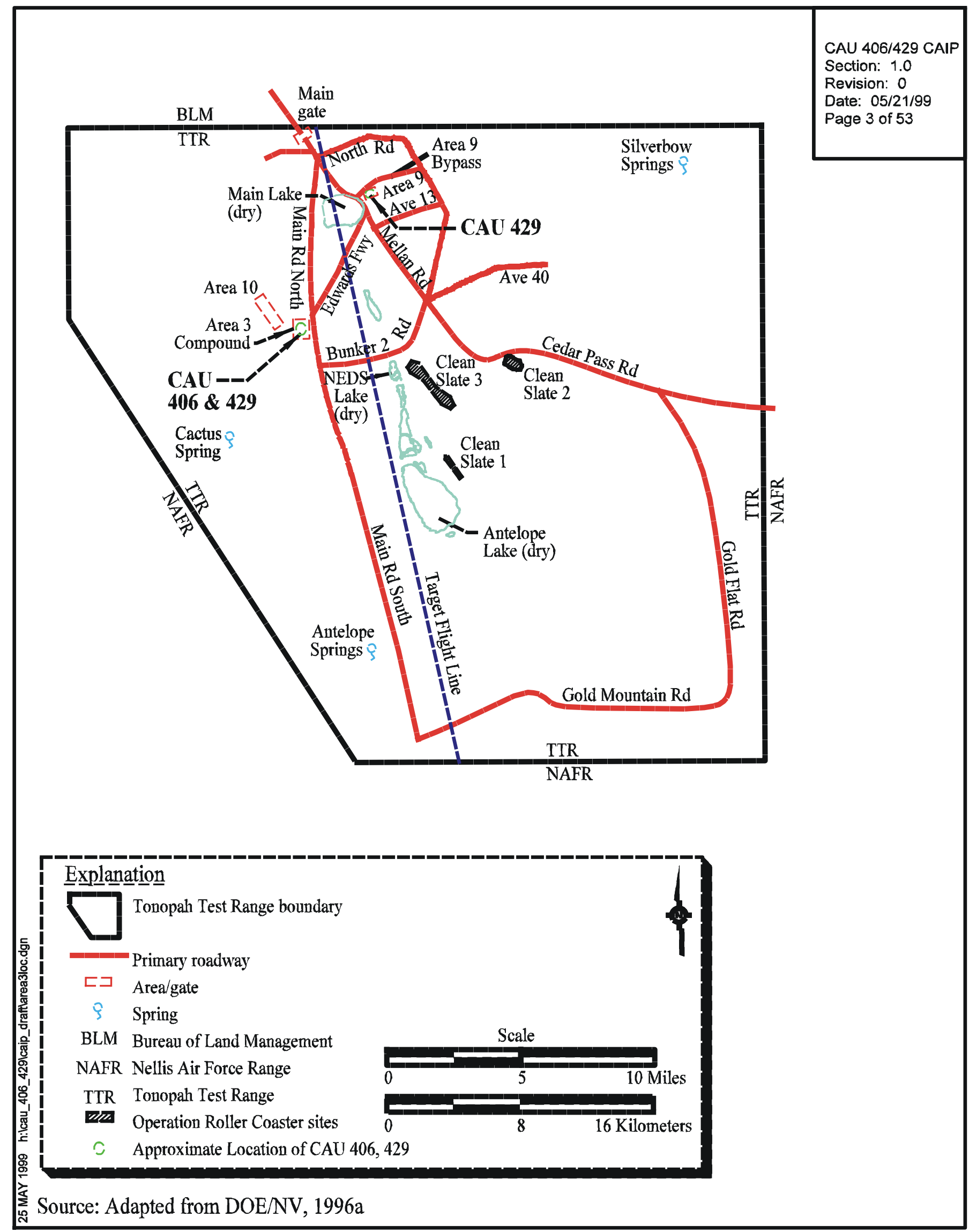

Figure 1-2

Location of Area 3 \& Area 9, Tonopah Test Range 


\subsection{Purpose}

The purpose of the corrective action investigation plan is as follows:

- Locate or verify the UDP locations.

- Determine the UDP configurations.

- Identify the presence and nature of the contaminants of potential concern (COPCs) within the UDP.

- Determine the vertical and lateral extent of COPC migration.

- Provide sufficient data to develop and evaluate appropriate corrective actions for each CAS.

This CAIP was developed using the U.S. Environmental Protection Agency's (EPA) Data Quality Objectives (DQOs) (EPA, 1994) process to clearly define the goals for collecting environmental data, to determine data uses, and to design a data collection program that will satisfy these goals and uses. A DQO scoping meeting was held prior to preparation of this plan; a brief summary of the DQOs is presented in Section 3.4. A more detailed summary of the DQO process and results is included in Appendix A.

\subsection{Scope}

The scope of this CAIP is to resolve the problem statement identified in the DQO process, which states that potentially hazardous wastes were discharged to the UDP systems that comprise CAU 406 and CAU 429 and that existing information about the nature and extent of contamination is insufficient to evaluate and select preferred corrective actions for these sites (see Appendix A). Therefore, the scope of the corrective action investigation for CAU 406 and CAU 429 includes the following tasks:

- Determine the UDP locations using video survey, utility location devices, and excavation, as necessary.

- Evaluate the UDP construction and configuration.

- Collect surface and near-surface samples using direct-push techniques at UDP locations where discharge to the ground surface may have occurred. 
- Drill boreholes using a hollow-stem auger or other suitable method capable of reaching the expected vertical extent of COPCs, penetrating potential leach rock materials (e.g., concrete or gravel), and providing suitable core for sample collection and logging of subsurface conditions.

- Conduct discrete field screening to direct drilling and sampling activities and provide an initial assessment of surface and subsurface impact.

- Collect subsurface soil samples for field screening, off-site laboratory analysis, geotechnical, and biological parameter analyses, as necessary.

- Log core to assess soil characteristics.

\subsection{CAIP Contents}

Section 1.0 of this CAIP provides an introduction to this project, including the purpose and scope for this corrective action investigation. The remainder of the document details the investigation strategy and complies with FFACO (1996) requirements that CAIPs address the following elements:

- Management

- Technical aspects

- Quality assurance

- Health and safety

- Public involvement

- Field sampling

- Waste management

The managerial aspects of this project are discussed in the DOE/NV Project Management Plan (DOE/NV, 1994b) and the site-specific Field Management Plan that will be developed prior to field activities. The technical aspects of this CAIP are contained in Section 3.0 and Section 4.0 of this document and in the DQO summary presented in Appendix A. General field and laboratory quality assurance and quality control (QA/QC) issues, including collection of quality control (QC) samples, are presented in the Industrial Sites Quality Assurance Project Plan (QAPP) (DOE/NV, 1996c). In addition, the methods for field QA/QC are further discussed in approved procedures. Field activities will be performed according to the current version of the Environmental Restoration Project Health and Safety Plan (HASP) (DOE/NV, 1998), and the approved site-specific HASP (SSHASP) written prior to the start of field work. As required by the DOE Integrated Safety Management System, these 
documents outline the requirements for protecting the health and safety of the workers and the public, and procedures for protection of the environment. No CAU-specific public involvement activities are planned at this time; however, an overview of public involvement is documented in the "Public Involvement Plan" in Appendix V of the FFACO (1996). Field sampling activities are discussed in Section 4.0 of this CAIP; waste management issues are discussed in Section 5.0. The project schedule and records availability information for this CAIP are discussed in Section 6.0, while Section 7.0 provides a list of project references. 


\subsection{Facility Description}

Prior to the installation of a consolidated sewer system between the late 1980s to the early 1990s, seven UDPs at the TTR were used to dispose of effluent from maintenance buildings and photography shops. Corrective Action Unit 406 consists of three UDPs and their associated discharge systems:

- One Heavy Duty Maintenance Shop, Building 03-74 UDP

- Two Uninterrupted Power Supply Building 03-58 UDPs

Corrective Action Unit 429 consists of four photoshop UDPs and their associated distribution systems:

- Two Area 3 Photoshop, Building 03-55 UDPs

- $\quad$ Two Area 9 Mobile Photographic Laboratories UDPs

Process knowledge relating to TTR UDP site histories as examined during the DQO process (Appendix A). This information includes TTR reports describing previous field efforts and sampling results, historical aerial photographs, engineering drawings and site maps, and interviews with TTR personnel.

\subsection{Physical Setting}

The Heavy Duty Maintenance Shop UDP is most likely located at the south end of the Area 3 West Gate culvert. The UPS UDPs are located in Area 3 approximately 3 meters (m) (10 feet [ft]) west of Building 03-58. The Area 3 Photoshop primary UDP is approximately $68 \mathrm{~m}(225 \mathrm{ft})$ south of Building 03-55. The secondary UDP is $9 \mathrm{~m}$ (30 ft) southeast of the primary UDP. The Area 9 Mobile Photographic Laboratories UDPs are located near the northeast corner of Building 09-52.

Surface soils around the UDP sites consist of sand, gravel, and cobbles with sparse vegetation. Overall topography slopes gently to the northwest with surface drainage generally flowing in the same direction for most of the Area 3 UDPs. A gentle southward sloping gradient near the Area 3 Photoshop UDPs may cause surface drainage flow to the southwest. Depth to ground water is estimated at 110 to $120 \mathrm{~m}$ (360 to $394 \mathrm{ft}$ ) below ground surface (bgs) at Area 3 and approximately 
$40 \mathrm{~m}(131 \mathrm{ft}) \mathrm{bgs}$ at Area 9. The groundwater flow direction is generally to the north-northwest at Area 3 and to the southwest at Area 9 (DOE/NV, 1996a).

\subsection{Operational History}

The exact UDP measurements and configurations are unknown for all four CASs. Typically, UDPs at the TTR were constructed by drilling a borehole about $1 \mathrm{~m}(3 \mathrm{ft})$ in diameter or by excavating a pit about $3 \mathrm{~m}(10 \mathrm{ft})$ deep. The UDP boreholes are usually lined with corrugated steel culvert pipe, steel drums, or other material. After drilling or excavation, the UDP is filled with gravel or other leach rock (e.g., concrete rip-rap). The gravel or leach rock may extend below the bottom of the UDP lining. The liquid waste percolated (or seeped) through the bottom of the UDP into the surrounding soil layers. A cross-sectional view of a typical UDP is shown in Figure 2-1. Specific operational information and construction details for the CAU 406 and CAU 429 UDPs are described in the following sections.

\subsubsection{Area 3 Heavy Duty Shop UDP}

The Area 3 Heavy Duty Shop, Building 03-74 was constructed and became operational between 1981 and 1983 and is currently used to service heavy equipment and generators. When the Heavy Duty Shop was constructed, the floor drains were connected to the drains from a Steam Cleaning Pad located west of the shop. The Steam Cleaning Pad was constructed during the late 1960s. Effluent from the Steam Cleaning Pad and Heavy Duty Shop was discharged via an underground pipeline to a UDP approximately $180 \mathrm{~m}(600 \mathrm{ft})$ northwest of the Heavy Duty Shop near the west gate entrance to the Area 3 Compound (Figure 2-2). Little information is known about the configuration of this UDP and the integrity of the pipeline. Interviews with former TTR employees suggest the UDP may have been a gravel-filled pit rather than a gravel-filled, lined, large-diameter boring.

The UDP frequently clogged and effluent would overflow onto the Steam Cleaning Pad and the floor of the Heavy Duty Shop. Interviews with former TTR workers indicate the gravel pit was excavated periodically when it became clogged with waste liquids. The resultant contaminated fill material was disposed of in nearby landfills. The use of the UDP was most likely discontinued between 1985 and 1988. However, during the period from 1985 to 1993, there is uncertainty whether the effluent continued to be discharged to this UDP or the nearby septic waste systems addressed as CAU 427. 


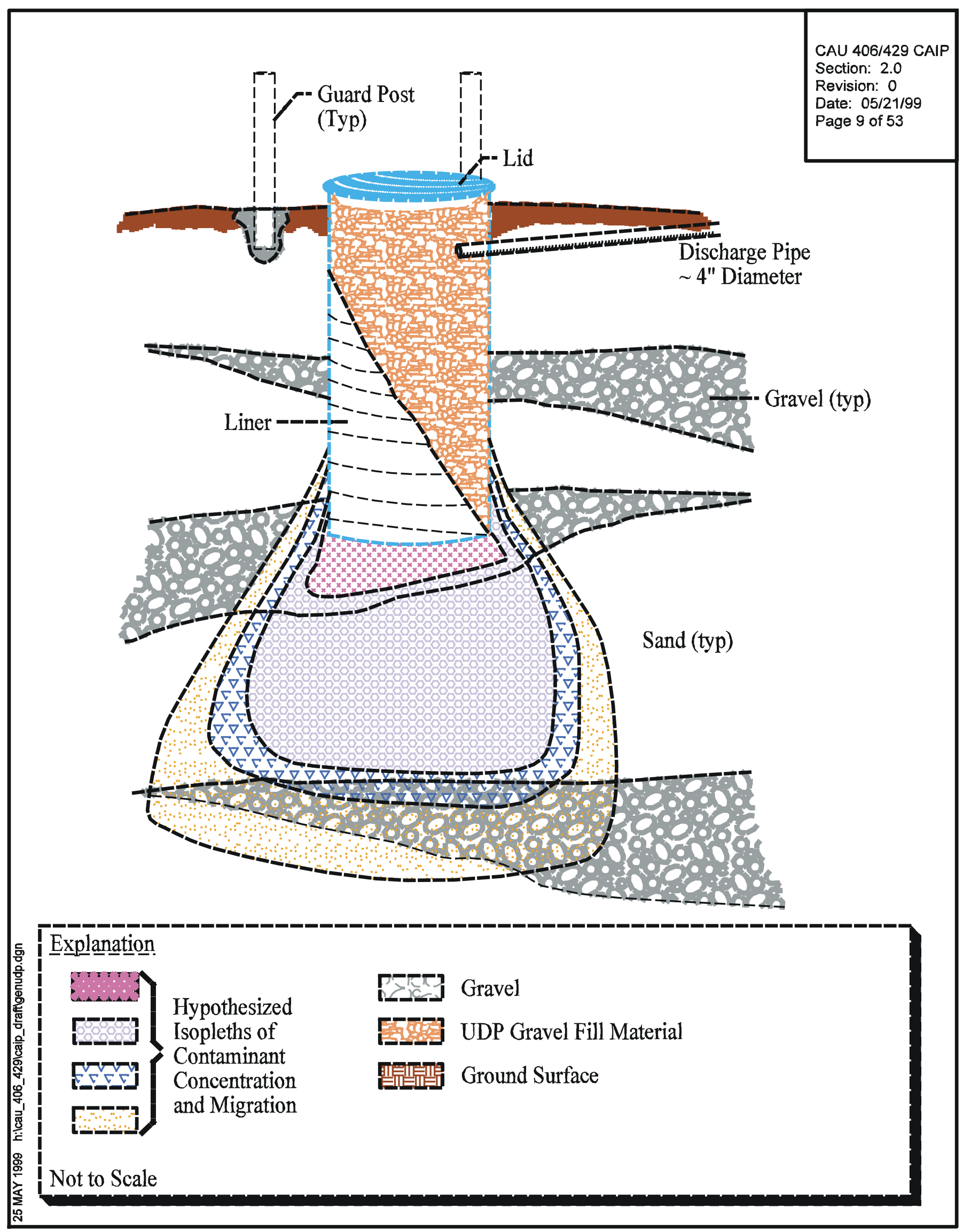

Figure 2-1

Cross-Sectional View of a Typical UDP Configuration 


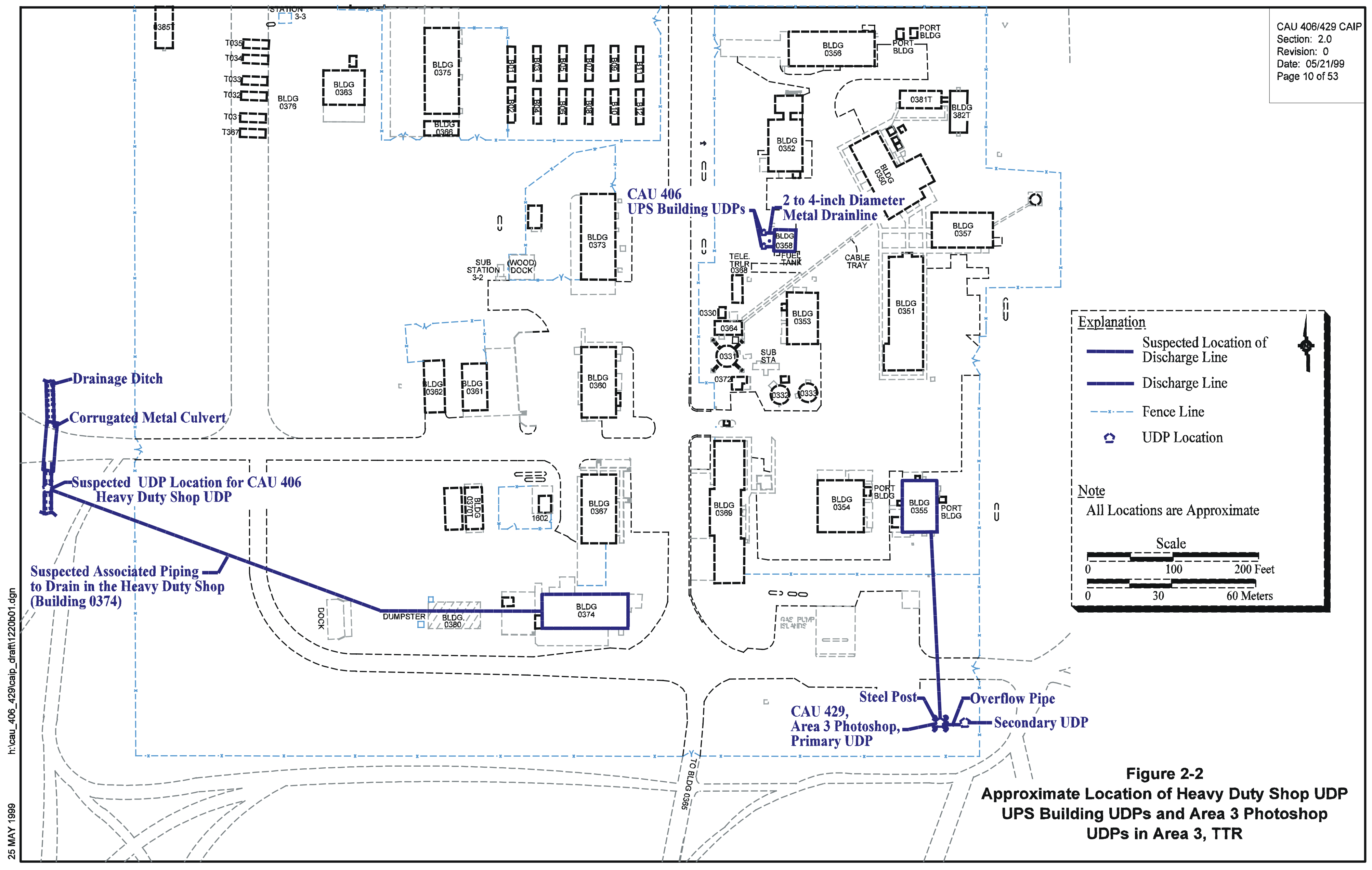


During the mid-to-late 1980s, the drain pipes from the Steam Cleaning Pad and the Heavy Duty Shop may have been disrupted or rerouted because of construction activities such as the installation of a water supply line and construction of the nearby Light Duty Shop (Building 03-80). Effluent from the Steam Cleaning Pad and the Heavy Duty Shop drains has been rerouted through an oil-water separator into the Area 3 Consolidated Waste System since about 1993.

The effluent discharged from the Steam Cleaning Pad and Heavy Duty Shop operations to the UDP consisted of water potentially containing petroleum products, hydraulic fluids, solvents, corrosives, Resource Conservation and Recovery Act (RCRA) metals, paint, soap, antifreeze, acetylene, and other chemicals associated with the Heavy Duty Shop and steam cleaning operations. Trucks that carried depleted uranium (DU) may have been washed at the Steam Cleaning Pad, introducing DU particles into the drain system and to the UDP (Karas, 1993; West, 1998); however, this practice is in question (Smith, 1998).

\subsubsection{Area 3 Uninterrupted Power Supply Building UDPs}

The Area 3 UPS Building 03-58 and two UDPs were constructed in 1970. The UPS Building is used to store auxiliary generators to produce emergency power needed for essential electrical systems during power outages in the Area 3 Compound. The emergency power plan utilizes a battery back-up system and a diesel-generator system. No transformers are located in the UPS Building. Two generators located on the floor of the UPS Building may have leaked diesel fuel, motor oil, antifreeze, and possibly other constituents and subsequently discharged through drain gutters located beneath the generators (Quas, 1998). The drains discharged into two UDPs located about $3 \mathrm{~m} \mathrm{(10} \mathrm{ft)} \mathrm{to} \mathrm{the} \mathrm{west}$ of the UPS Building (see Figure 2-2).

The UDPs may be either subgrade gravel filled 55-gallon (gal) drums, or possibly unlined gravel pits with a diameter of approximately $1.2 \mathrm{~m}(4 \mathrm{ft})$. The depth of both UDPs are unknown. They are connected to the UPS Building by two underground 5 to10-centimeter (cm) (2 to 4-inch [in.]) metal drain pipes. The exact locations of the drain pipes are not known and surface manifestations of the UDPs are no longer discernible. The UPS UDPs were in use until the late 1980s (Quas, 1998).

In July 1993, a diesel fuel spill from an aboveground fuel tank adjacent to the UPS Building resulted in contaminated soils in an area southwest of the supposed UDP locations. The contaminated soil 
from this release was subsequently excavated and removed (DOE/NV, 1996a; Quas, 1993). Approximately 106 liters (L) (32 gal) of diesel fuel were released to the ground surface on January 16, 1998, when a float valve malfunctioned in the UPS Building. Contaminated soil from this release was excavated and removed from an area near the northwest corner of the building. However, some diesel-contaminated soil underneath the UPS Building was not removed; approximately 10 cubic yards of contaminated soil are estimated to remain under the foundation of the building (SNL, 1998). It is unknown if the removal of contaminated soil from historic surface spills near Building 03-58 resulted in the removal of the UDPs features.

At the present time, a 3,790-L (1,000-gal) aboveground diesel tank is located directly to the west of the building.

\subsubsection{Area 3 Photoshop UDPs}

The Area 3 Photoshop Building 03-55 was completed in 1964 for setup, operation, and storage of camera equipment and for processing black and white and color negatives for photographs and films. Daily film processing operations produced liquid effluent that was discharged to a UDP approximately $68 \mathrm{~m}$ (225 ft) south of the Photoshop (Figure 2-2). The photoshop effluent most likely consisted of large amounts of water and low concentrations of photoprocessing waste, including silver nitrate, acids, caustics, corrosives, and solvents. The UDP was ultimately unable to accommodate the waste volume generated by the photoshop (as evidenced by overflow at the ground surface) and a second UDP was constructed approximately $9 \mathrm{~m}(30 \mathrm{ft})$ east of the initial UDP. The exact time period the photoshop discharged waste to the initial UDP is unknown, but discharges probably occurred from about 1964 to about 1989. The exact installation date for the secondary UDP is unknown, but installation occurred after 1964. Building 03-55 is still in use for camera maintenance and limited photoprocessing; however, in 1989 the effluent from the photoshop was rerouted to the Area 3 Consolidated Waste System and use of the UDPs was discontinued.

Both of the Area 3 Photoshop UDPs are cased with corrugated steel culvert pipe that measures approximately $1.2 \mathrm{~m}(4 \mathrm{ft})$ in diameter and extends approximately $3 \mathrm{~m} \mathrm{(10} \mathrm{ft)} \mathrm{bgs.} \mathrm{In} \mathrm{1993,} \mathrm{the} \mathrm{initial}$ UDP culvert pipe was visible but badly corroded; the culvert pipe has since disintegrated. Currently, the soil around the initial UDP forms a surface depression and is surrounded by guard posts that 
indicate the location of the UDP. The second UDP is marked by a culvert pipe that extends approximately $0.5 \mathrm{~m}(1.6 \mathrm{ft})$ above ground surface and is in good condition.

The peak discharge to the Photoshop UDPs was approximately 950,000 L (250,000 gal) per year (Phelan, 1988). Most of the effluent was water used for temperature control or film washing. A 1984 environmental audit reported that 1,730 L (457 gal) of waste chemicals were discharged to the Photoshop UDPs (Schirber, 1984). Sometime after 1987, a silver recovery system was installed on the Houston film processor inside the Photoshop; however, interviews indicate the recovery system was not well-maintained and silver often drained to the UDPs when the system was over-saturated.

\subsubsection{Area 9 Mobile Photographic Laboratory UDPs}

At Area 9, X-ray radiography was conducted at two on-site mobile photoprocessing laboratories installed near the Electronics Shop, Building 09-52. Radiography was frequently conducted to inspect the internal components of weapon test units. One of the mobile photoprocessing laboratories is Building 09-15 (a transportainer). The Building 09-15 transportainer was brought to Area 9 between 1982 and 1984. The second mobile photoprocessing laboratory, Trailer 927, was brought to Area 9 between 1984 and 1987 and abandoned in 1990. Both mobile photoprocessing laboratories produced comparatively small volumes of waste streams similar to the Area 3 Photoshop. Relatively large amounts of water and low concentrations of photoprocessing waste were discharged to the breather riser of the septic tank associated with the Building 09-52 septic system. This CAS is the only UDP site that has septic system components.

The Electronics Shop, Building 09-52 septic system includes a 2,840-L (750-gal) underground septic

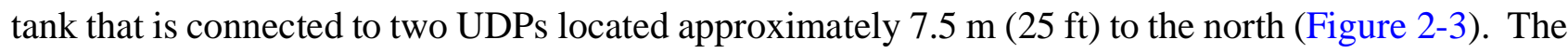
UDPs are approximately $9 \mathrm{~m}(28 \mathrm{ft})$ apart. This septic system was built sometime after 1974 and was originally installed to serve only the restroom and breakroom of Building 09-52. The septic tank reportedly did not receive any industrial waste associated with test activities or processes within the electronics shop (Samuelson, 1998). The drains within the mobile photoprocessing laboratories were connected to the breather riser of the septic tank by aboveground drain pipes approximately $10-\mathrm{cm}$ (4-in.) in diameter. Information has not been identified that indicates the drain pipes leading from the Building 09-52 restroom, Trailer 927, and the 09-15 transportainer building have been sealed to 


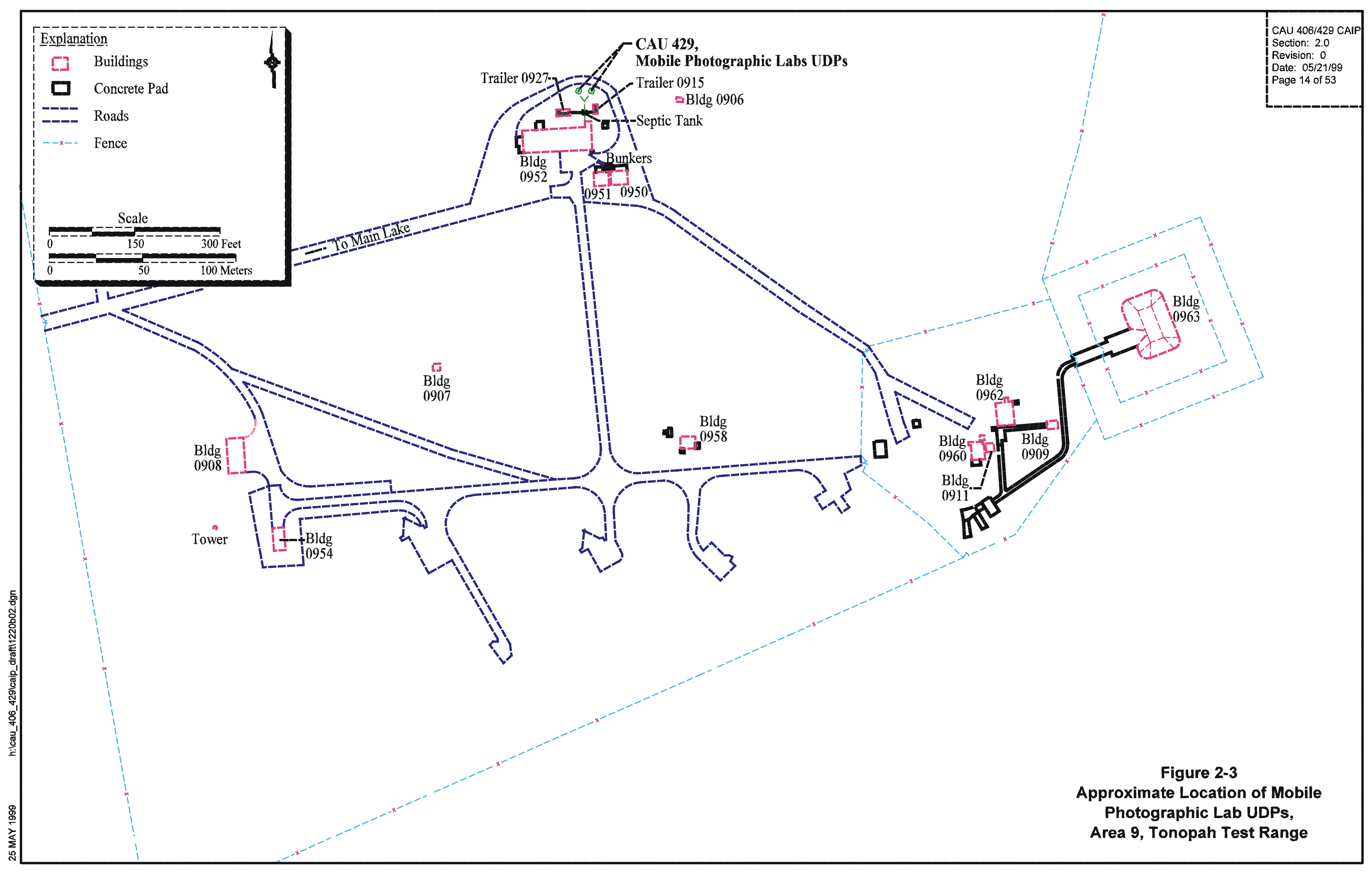


eliminate the possibility of recent effluent discharge into the septic tank and UDPs. However, water has been shut off to Building 09-52 and portable toilets were established nearby.

At the surface, the UDPs are visible as approximately $1-\mathrm{m}$ by $1-\mathrm{m}$ (3-ft by $3-\mathrm{ft})$ squares constructed with concrete blocks and covered by wooden pallets. Below the bottom of the blocks, the UDPs are believed to increase in diameter to $1.5 \mathrm{~m}(5 \mathrm{ft})$ and extend to $3 \mathrm{~m}(10 \mathrm{ft}) \mathrm{bgs}$. It is unknown if the UDPs are lined; however, the UDPs are believed to be gravel-filled.

The amount of effluent discharged from the Area 9 mobile photoprocessing laboratories is unknown. The exact period that photoprocessing effluent was discharged to the UDPs is uncertain, but most likely occurred between 1982 to the mid-1990s. Use of the Area 9 Mobile Photoprocessing Laboratories for X-rays was discontinued when digital radiography technology use began in the mid-1990s.

\subsection{Waste Inventory}

No documented inventories of waste removal or waste disposal were identified for any of the UDPs. The total volumes and concentrations of liquid waste discharged to the UDPs are generally unknown. Process knowledge of potential waste inventories for both CAU 406 and 429 is discussed in this section.

The CAU 406 UDPs received liquid waste associated with motorized equipment maintenance and operation and steam cleaning operations which possibly includes petroleum products, hydraulic fluids, coolants, cleaning supplies, and solvents. Only trace amounts of these products are expected. Depleted uranium particles may have been discharged through the Steam Cleaning Pad drains; however, reports of this practice are in question. The length of operations for the Heavy Duty Shop UDP are poorly constrained between 1981 and 1988 while the Steam Cleaning Pad has been in operation since the 1960s. The dates of operation for the UPS Building 03-58 UDPs are uncertain; however, the building and UDPs were constructed around 1970.

The CAU 429 UDPs received waste associated with photoprocessing which may include silver as well as acids, caustics, corrosives, and solvents. The length of operations for the Area 3 Photoshop are between 1964 and 1989 with an estimated 950,000 L (250,000 gal) per year of potentially 
contaminated water released to the two UDPs. Operations for the two Mobile Photographic Laboratories at Area 9 are constrained between the early 1980s to early 1990s. The septic tank may still contain septage discharged from Building 09-52.

\subsection{Release Information}

The UDPs in CAU 406 and CAU 429 are typically subgrade excavations filled with gravel in which liquid wastes were discharged via distribution lines and allowed to percolate into the surrounding soil for disposal. Exact quantities of liquids released to each UDP are unknown. Migration of COPCs will be limited both laterally and vertically due to expected low concentrations of COPCs, lack of a driving force, and relatively low mobility of COPCs.

Historical information suggests that potential UDP surface overflows may have occurred at both the Area 3 Photoshop UDP and the Heavy Duty Shop UDP. Potential overflows at the primary Area 3 Photoshop UDP may have impacted soils most likely in a radial pattern at the surface and/or near surface. The Heavy Duty Shop UDP may have impacted surface and/or near surface soils laterally to the north or south of the west gate culvert for an undetermined distance.

The UPS Building 03-58 UDP systems may have been impacted by historic accidental releases of diesel fuel that occurred near or in the building. Although most of the contaminated soil was removed, historic surface spills and their subsequent remediation may impact this CAS in at least two ways. The features of the UDPs may have been coincidentally removed during the remediation effort of the surface spills. Secondly, distinguishing between diesel related to the UDP system and diesel remaining after the clean-up operations of surface spills will be difficult. Field data generated during this investigation will have to be evaluated against previous sampling efforts in an attempt to distinguish between the separate events. Known diesel-contaminated soil remains under Building 03-58 (DOE/NV, 1996a; SNL, 1998).

\subsection{Investigative Background}

There have been no geophysical surveys conducted for any of the UDP systems. Sampling data was not identified for any of the UDPs. However, one sampling event was identified for the septic tank associated with the Mobile Photographic Lab UDPs in Area 9. Soil sample results from the 1998 
diesel fuel spill at the UPS building were also identified. Both of these sampling events contribute information on the potential COPCs that can be expected during the investigation of the relevant UDPs and are briefly described below.

A sampling effort was conducted in 1993 to collect aqueous and sludge samples from the Area 9 Building 09-52 septic tank (IT, 1994). Analytical results of the aqueous sample indicate that silver is present, but concentrations are below the Toxicity Characteristic standard of 5.0 milligrams per liter $(\mathrm{mg} / \mathrm{L})$. An elevated total metal silver concentration of 29.3 milligrams per kilogram $(\mathrm{mg} / \mathrm{kg}) \mathrm{was}$ measured in the sludge sample, which may indicate that it exceeds the Toxicity Characteristic standard of $5.0 \mathrm{mg} / \mathrm{L}$ when divided by 20 ; however, additional sampling of the sludge by Toxicity Characteristic Leaching Procedure (TCLP) for silver would be necessary before a hazardous waste determination could be made. A gross beta concentration of 147 picocuries per liter (pCi/L) was measured in the aqueous sample; however, the sludge sample did not indicate gross beta at abnormal levels. No other contaminants were present in elevated concentrations.

Environmental samples were taken by Sandia National Laboratories (SNL) personnel during the excavation and removal of contaminated soil resulting from the January 16, 1998, diesel fuel spill at the UPS Building 03-58. According to data presented in the In-Situ Closure Plan Area $3 U P S$ Building (SNL, 1998), the contaminant present is diesel fuel and the contamination is confined to the site. The SNL's investigation defined the extent of contamination to be approximately $1.8 \mathrm{~m}(6 \mathrm{ft})$ bgs. Analytical samples taken from soil adjacent to and beneath the building foundation on February 18, 1998, indicate total petroleum hydrocarbon (TPH) concentrations above $100 \mathrm{mg} / \mathrm{kg}$. Two additional soil samples were collected on March 4, 1998, after further excavation of soil beneath the building foundation was suspended. One sample was taken from the area adjacent to the foundation and the other from the contaminated soil approximately two feet under the foundation (sidewall). The results indicate TPH concentrations above $100 \mathrm{mg} / \mathrm{kg}(3,440$ and 3,740 mg/kg, respectively). The depth and volume of remaining contaminated soil beneath the building foundation are unknown. According to the Closure Plan, the remaining contaminated soil beneath the UPS Building does not pose a threat to human health and the environment.

In accordance with the DOE/NV National Environmental Policy Act (NEPA) compliance program, a NEPA checklist will be completed prior to commencement of site investigation activities at CAU 406 
and CAU 429. This checklist compels DOE/NV projects to evaluate their proposed project against a list of several potential environmental impacts which include, but are not limited to, air quality, chemical use, waste generation, noise level, and land use. Completion of the checklist results in a determination of the appropriate level of NEPA documentation by the DOE/NV NEPA Compliance Officer.

Site investigation activities associated with CAU 406 and CAU 429 have been identified and documented in the Final Environmental Impact Statement for the Nevada Test Site and Off-Site Locations in the State of Nevada (DOE/NV, 1996b). 


\subsection{Objectives}

The DQOs are qualitative and quantitative statements that specify the quality of the data required to support potential courses of action for the UDPs. The DQOs were developed to clearly define the purposes for which environmental data will be used and to design a data collection program that will satisfy these purposes. One element of the DQO process is the formulation of a conceptual site model.

\subsection{Conceptual Site Model}

The conceptual site model defines the expected nature and extent of contamination at the UDPs based on assumptions formulated using information presented in Section 2.0 and discussed during the DQO process. The model is used to identify appropriate sampling strategy and data collection methods. The cross-section in Figure 2-1 depicts a graphical representation of the estimated COPCs. The conceptual site models and assumptions for the CAU 406 and CAU 429 UDPs developed in the DQO process are presented in Appendix A and are summarized in this section.

The description of the conceptual site model presented below is applicable to both CAUs based on similar historical operations, process knowledge, and assumptions for all UDPs included in this project. In addition to the general assumptions outlined in the conceptual site model below, Sections 3.1.1 and 3.1.2 discuss unique characteristics and assumptions specific to each CAS within CAU 406 and CAU 429, respectively.

- The volume and concentrations of the COPCs are unknown but contamination is expected to be present and concentrated at the base of the UDPs.

- COPCs primarily in liquid form were released to the UDPs. The effluent was mainly water with small amounts of contaminants.

- The UDPs are no longer in service; however, Building 09-52 septic system is functional but abandoned.

- Contamination is not expected to extend laterally beyond 10 times the width of the UDP. 
- Vertical contamination is not expected to exceed three times the vertical dimension of the UDP below the UDP base. Migration is primarily gravity controlled, but geologic control at depth may influence or limit contaminant migration.

- Relatively low contaminant concentrations and volume, low mobility of constituents, and a lack of a driving force will limit the subsurface lateral and vertical migration of COPCs.

- Arid climate limits infiltration and high evapotranspiration rates restrict the mobility of COPCs.

- Nearby utilities and buildings, adverse weather conditions, restricted access, and range activities may present practical and/or physical constraints to the field investigation.

- Potential exposures to personnel would be oral ingestion, inhalation, or dermal contact of COPCs in the soil during excavation.

- Future land use is expected to remain similar to the current use (light industrial).

\subsubsection{Corrective Action Unit 406}

Corrective Action Unit 406 includes "maintenance" UDPs associated with the Heavy Duty Shop (Building 03-74) and the UPS Building (Building 03-58) in Area 3. The locations and configurations of the UDPs in CAU 406 are poorly constrained. The primary COPCs in the CAU 406 UDPs are hydrocarbons.

\section{Heavy Duty Shop UDP, CAS 03-51-002-0374}

- The UDP is assumed to have received waste only from the Heavy Duty Shop and Steam Cleaning Pad drains.

- The Heavy Duty Shop UDP may have discharged to the surface and the subsurface.

- The UDP may have received radioactive material derived from washing trucks that transported DU components.

- A gravel pit near the UDP location was reportedly excavated periodically and the resultant contaminated fill material disposed of in the Area 3 landfill(s). This activity may have reduced the volume of potentially contaminated soil near the UDP.

- Potential disruptions of the discharge line from unrelated maintenance and construction events may complicate locating any existing and intact sections of discharge pipe. 
Uninterrupted Power Supply Building UDPs, CAS 03-51-003-0385

- No liquid waste was intentionally disposed of through the floor drains.

- The UDP features may have been removed during unrelated historical diesel-contaminated soil remediation.

- Diesel-contaminated soil remains under Building 03-58. Distinguishing between diesel related to the UDP system and diesel remaining after the clean-up operations of two surface spills will be difficult.

\subsubsection{Corrective Action Unit 429}

Corrective Action Unit 429 includes photoprocessing UDPs associated with the Area 3 Photoshop (Building 03-55) and two Mobile Photographic Laboratories in Area 9 (at Building 09-52). The locations and configurations of the UDP features are well defined for CAU 429. The primary COPCs are silver and other photoprocessing waste.

\section{Area 3 Photoshop UDPs, CAS 03-51-001-0355}

- The UDPs are assumed to have received waste only from Building 03-55 via the discharge line.

- The primary UDP was constructed in 1964; however, the secondary UDP installation date is unknown. Both units operated until approximately 1989.

- Surface overflow may have occurred at the primary UDP for Building 03-55 prior to the installation of the secondary UDP.

- The UDPs may have received up to $950,000 \mathrm{~L}(250,000 \mathrm{gal})$ of effluent per year with an estimated chemical/water mixture of 0.1 gram per $370 \mathrm{~L}$ (100 gal) of water.

Area 9 Mobile Photographic Lab UDPs, CAS 09-51-001-0952

- The effluent of concern originated in the two mobile photographic laboratories which operated from the early 1980 s through the early 1990 s. 
- The septic system associated with the Building 09-52 restroom is functional but was abandoned a couple of years ago.

- No process waste associated with Building 09-52 electronics shop activities was disposed of through the bathroom drains.

Groundwater impact is unlikely because depth to groundwater is extensive (greater than $39 \mathrm{~m}$ [130 ft]

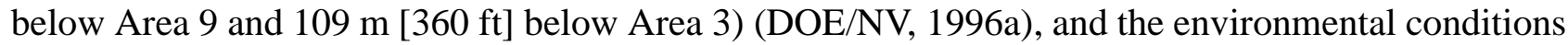
at the site (i.e., arid climate, high evaporation) are not conducive to downward migration of COPCs.

\subsection{Contaminants of Potential Concern}

During the DQO process, COPCs for each CAS were identified through process knowledge and site history. The COPCs for both CASs in CAU 429 include volatile organic compounds (VOCs), semivolatile organic compounds (SVOCs), and RCRA metals associated with photoprocessing waste. The primary COPCs for CAU 406 are hydrocarbons associated with equipment and vehicle maintenance operations. The following lists provide the site-specific analytes to be measured to determine the nature of potential contamination at each CAS:

\section{Heavy Duty Shop UDP:}

- VOCs

- SVOCs

- Total RCRA metals

- Total polychlorinated biphenyls (PCBs)

- TPH

As a precautionary measure, 25 percent of the soil samples collected during the Heavy Duty Shop UDP site investigation will be submitted for isotopic uranium analysis.

\section{Uninterrupted Power Supply Building UDPs:}

- TPH-diesel/waste oil

- Total PCBs 
Area 3 Photoshop UDPs:

- Total RCRA metals

- VOCs

- SVOCs

The TCLP for silver will be conducted at the discretion of the Site Supervisor. The decision of which samples to submit will be based on field observations, X-ray fluorescence (XRF) field screening, and waste management requirements.

\section{Area 9 Mobile Photographic Labs UDPs:}

- Total RCRA metals

- VOCs

- SVOCs

The TCLP for silver will be conducted at the discretion of the Site Supervisor. The decision of which samples to submit will be based on field observations, XRF field screening, and waste management requirements.

While radionuclides are not anticipated at any other UDP sites, samples will be collected for gamma spectroscopy analysis if field screening results exceed field screening levels. Tables A.3-1 through A.3-3 in Appendix A list the COPCs to be analyzed for each CAS, including field screening methods and levels and preliminary action levels (PALs). Appendix C provides the analytical requirements which include minimum reporting limits, regulatory limits, analytical methods, precision, and accuracy for all the analytes.

\subsection{Preliminary Action Levels}

The following subsections describe the field screening levels and PALs for CAU 406 and CAU 429. Field screening levels for on-site field screening methods will be used to determine the presence of contamination and guide the investigation. 


\subsubsection{Field Screening Levels}

The following field screening levels will be used for on-site field screening methods:

- Volatile organic compound headspace screening levels using a photoionization detector and a warm water bath are established at 20 parts per million (ppm) or 2.5 times background, whichever is greater.

- Total petroleum hydrocarbon screening levels using appropriate field screening methods (i.e., Hanby ${ }^{\mathrm{TM}}$ or other test kit) are established at $100 \mathrm{ppm}$.

- Silver screening levels using XRF techniques are established at less than $100 \mathrm{ppm}$.

- Radiation (alpha, beta, and gamma) screening is defined as the mean background activity level plus two times the standard deviation of the mean background activity level (to be determined prior to start of field activities) and monitored during sampling.

Concentrations exceeding field screening levels will indicate potential contamination at that sample location. This information will be documented, and the investigation will be continued to delineate the extent of the contamination. Additionally, this data may also be used to select discretionary laboratory sample locations.

\subsubsection{Chemical Preliminary Action Levels}

Off-site laboratory analytical results will be compared to the following PALs to evaluate the need for possible corrective actions:

- NDEP Corrective Action Regulations (Nevada Administrative Code [NAC], 1998b) (for purposes of this investigation, EPA Region IX Preliminary Remediation Goals [PRGs] for industrial soils are assumed as the PALs [EPA, 1998])

- TPH concentrations above the TPH limit of $100 \mathrm{ppm}$ per the NAC 445A.2272 (NAC, 1998b)

The comparison of laboratory results to preliminary action levels will be discussed in the Corrective Action Decision Document (CADD). Laboratory results above action levels indicate the presence of COPCs at levels that may require corrective action. The evaluation of potential corrective actions and the justification for a preferred action will be included in the CADD based on the results of this field investigation. 


\subsubsection{Radiological Preliminary Action Levels}

The PALs for radionuclides are isotope-specific and are defined as the maximum concentration for that isotope found in environmental samples taken from undisturbed background locations. Environmental background samples previously taken in the vicinity of Area 3 and Area 9 at the TTR (in the vicinity of CAUs 406 and 429) will be compared with the results for environmental samples taken from other undisturbed background locations on the TTR. In addition, the radionuclide concentrations in the CAUs 406 and 429 and TTR background samples will be compared with the radionuclide concentrations found in environmental samples taken from undisturbed background locations in the vicinity of the NTS, presented in McArthur and Miller (1989) and Atlan-Tech (1992). The PAL for each isotope will be the maximum concentration of that isotope found in any of the samples taken from the undisturbed background location described above.

\subsection{DQO Process Discussion}

Details of the DQO process are presented in Appendix A. The DQO results for the UDPs indicated the need for a biased sampling approach. Due to potential subsurface migration of COPCs, an investigation consisting of subsurface sampling was identified. In addition, two locations (the Heavy Duty Shop UDP and the Area 3 Photo Shop UDP) have potential surface contamination that will be investigated. Table A.6-1 in Appendix A provides decision points and rules specific to each CAS that will be used to guide the field investigation. The COPCs, analytical methods, and reporting limits prescribed through the DQO process are provided in Appendix A. The precision and accuracy requirements are stated in Appendix $\mathrm{C}$. 


\subsection{Field Investigation}

This section of the CAIP contains the sampling approach for investigating the UDPs at the TTR. All sampling activities will be conducted in compliance with the Industrial Sites QAPP (DOE/NV, 1996c) and other applicable, approved procedures and instructions. Quality assurance and quality control requirements for field and laboratory environmental sampling are provided in Section 4.2.2 and in the Industrial Sites QAPP (DOE/NV, 1996c).

Field activities will be performed in accordance with an approved SSHASP which concurs with the U.S. Department of Energy (DOE) Integrated Safety Management System. Safety, health, and protection of the environment take precedence over expediency and short cuts. Site personnel will take every reasonable step to reduce the possibility of injury, illness, or accidents, and to protect the environment during all project activities. The following will be taken into consideration when assessing the hazards associated with the field activities:

- Potential hazards to site personnel and the public include, but are not limited to, chemicals (such as RCRA metals, VOCs, SVOCs, and TPH), adverse and rapidly changing weather, remote location, heavy equipment operations including drilling and excavation

- Proper training of all site personnel to recognize and mitigate the anticipated hazards

- Work controls to reduce or eliminate the hazards including engineering controls, substitution of less hazardous materials, and personal protective equipment

- Occupational exposure monitoring to prevent overexposures to hazards such as radionuclides, chemicals, and physical agents (heat, cold, and high wind)

- Use of the "as low as reasonably achievable" (ALARA) principle when dealing with radiological hazards

- Emergency and contingency planning and communications to include medical care and evacuation, decontamination and spill control measures, and appropriate notification of project management 


\subsection{Technical Approach}

The following list describes general activities that may be executed during the site investigations for CAU 406 and CAU 429. Specific details for individual field activities at each CAS are provided in Section 4.3.1 to 4.3.4.

- Perform video surveys to determine the location and condition of discharge pipes.

- Excavate areas where video survey fails to locate discharge pipes.

- Excavate at inferred CAU 406 UDP locations to identify UDP features.

- Collect surface and near-surface environmental samples at the Heavy Duty Shop UDP and the Area 3 Photoshop UDPs to investigate potential surface contamination.

- Collect environmental samples from within and around the septic tank at Area 9 Mobile Photographic Laboratories UDPs.

- Drill vertical boreholes at UDP locations where necessary.

- Drill step-out boreholes as necessary to delineate vertical and lateral extent of contamination.

- Conduct field screening for VOCs and radioactivity to direct excavation or drilling, and sampling activities.

- Conduct field screening for TPH only at CAU 406 locations. The TPH screening will not be conducted on any soil in which elevated radiation field screening results are detected.

- Conduct field screening for silver only at CAU 429 locations.

- Conduct laboratory analysis for CAS-specific COPCs.

- Collect quality control samples.

- Collect samples from native soils beneath a UDP at each site and analyze for geotechnical/hydrologic parameters.

- Collect and analyze bioassessment samples at CAU 406 at the discretion of the Site Supervisor if TPH field screening results suggest significant contamination. 


\subsection{Field Activities}

The subsurface investigation of both CAU 406 and CAU 429 may include, but are not limited to, excavation, direct-push methods, and drilling methods to locate and investigate underground discharge points and their associated discharge lines. Drilling will be the primary investigation tool used to evaluate and sample each identified UDP system except for the UPS Building UDPs where drilling will only be used if contamination is more extensive than anticipated. Damage to roads and utilities will be minimized during investigation activities.

\subsubsection{Video Survey}

Video surveys will be conducted using a commercial down-pipe camera system to locate and inspect UDP discharge pipes where the UDP locations are poorly constrained. Video surveys allow a visual assessment of the system's integrity and can be used to identify obvious breaches, unexpected branchings (i.e., tie-ins or off-shoots), and open joints. A radio locator which emits a signal that can be tracked at the ground surface may be coupled with the video setup and introduced into the piping. The discharge lines and UDP locations may be inspected and physically mapped by tracking the camera head inside the piping network. The survey may not be possible for some lines because of small pipe diameters (i.e., less than 7.5-cm [3-in.] diameter), limited access, pipe damage, blockage, or other factors. The video system can be decontaminated using standard techniques and equipment, and can be sheathed in disposable plastic to simplify decontamination activities, if necessary.

Additional entry points for the video system may be accessed by excavating at the required locations and cutting the discharge pipes as necessary. For investigation of discharge pipes where the video survey fails, excavation at selected locations will be conducted to identify and/or verify the location of the discharge lines.

If additional tie-ins are discovered, the line will be investigated to the source (if possible) and the investigation will be suspended until the NDEP is notified. The discovery of an unexpected contributing line may imply an additional source input and could increase the scope of the investigation. Similar decision rules apply if additional off-shoots or discharge points are discovered. 


\subsubsection{Excavation Activities}

Excavation activities will use a backhoe or shovel to obtain access to discharge lines or sampling locations. Excavation locations will be based on historical information, engineering drawings, surface features, and video surveys. Trenching to locate UDP discharge lines may be required, but may not be possible in some areas due to existing facilities and utilities. Sample collection is not planned during the excavation phase of any of the CASs, except at the UPS UDPs. However, if conditions are encountered during excavation or a video survey that warrant sampling (i.e., staining, odor, or broken pipes), then soil samples will be collected for analysis. Soil will be collected directly out of the backhoe bucket immediately upon retrieval. Excavation activities will uncover only enough pipe or material for inspection and/or sampling to reduce spoils and minimize the potential for damaging buried utilities. Excavated soils will be stored in a manner that will prevent run-on and run-off. When access to the subsurface at a particular location is no longer required, soil excavated during trenching operations will be returned to the excavation as close as practical to its original location.

\subsubsection{Direct-Push Methods}

The direct-push method may be used, as an alternative to drilling, to collect surface ( 0 to $0.3 \mathrm{~m}$ [0 to $1 \mathrm{ft}$ ] bgs) and near-surface ( 0.9 to $1.5 \mathrm{~m}$ [3 to $5 \mathrm{ft}$ ] bgs) samples at potential UDP surface overflow areas. This method may also be utilized at sites where mobilizing a drill rig may be inefficient or unnecessary. The number and placement of proposed sampling locations were determined from historical and process knowledge and are described in greater detail in Section 4.3. Extra soil remaining after the direct-push activities will be returned to the direct-push hole it was generated from.

\subsubsection{Soil Borings}

One boring will be advanced directly through the center of each identified UDP using a hollow-stem auger drill or another appropriate drilling method. Drilling will only be employed at the UPS Building UDPs if contamination detected by field screening or laboratory analysis extends beyond the maximum reach of the backhoe. Field screening and soil sample collection will be conducted at 1.5-m (5-ft) intervals to a depth of $12 \mathrm{~m}(40 \mathrm{ft})$ bgs until two consecutive, nondetect field screening 
results are obtained. If two consecutive, 1.5-m (5-ft) interval, nondetect field screening results are not

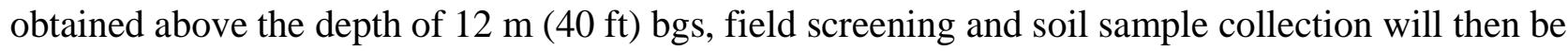
conducted at 3-m (10-ft) intervals, and drilling will continue until two consecutive, nondetect field screening results are obtained or the maximum drilling depth of the rig is reached.

If elevated field screening results are identified during advancement of the initial boring, step-out borings will be advanced to evaluate the extent of lateral and vertical contaminant migration. The locations of initial step-out borings will be dictated by individual site configurations. Based on field screening results, additional step-outs (beyond the initial step-outs) may also be needed to delineate the plume boundaries. At a minimum, step-out borings will be advanced to the lowest vertical extent of contamination (detected by field screening) in the initial UDP boring. Excess drill cuttings not collected as samples will be returned to the boring from which they originated or be containerized and managed as IDW. All boreholes will be filled to the ground surface with a bentonite grout mixture upon completion of sampling activities.

\subsubsection{Field Screening}

Field screening for radiation and VOCs will be conducted for all samples. Field screening for TPH will be conducted only at CAU 406. Field screening for silver (RCRA metal) will be conducted only at CAU 429. The field screening methods include screening for VOCs using a headspace method and screening for radioactivity using an alpha/beta scintillator (i.e., Electra ${ }^{\mathbf{T M}}$ ), and a sodium iodide (NaI) detector, or equivalents. The Hanby ${ }^{\mathbf{T M}}$ method or other hydrocarbon test kit will be used for TPH field screening. To avoid generating mixed waste, TPH screening will not be conducted on any soil in which elevated radiation field screening results are detected. Silver will be screened for in the field using a XRF instrument, if possible.

Field-screening results will provide information to establish the maximum depth of COPCs and the need for step-out borings. If field screening results exceed the field screening levels listed in Section 3.3, additional samples will be collected and step-outs performed using drilling methods as necessary. 


\subsection{Investigation Strategy for CAUs 406 and 429}

The DQO results for the UDPs indicate the need for multiple-phase approaches to investigate each individual CAS. The following subsections describe the investigative strategies for each CAS.

\subsubsection{CAU 406, Heavy Duty Shop UDP, CAS 03-51-002-0374}

A video camera survey will be attempted on the discharge lines associated with the Heavy Duty Shop UDP. The camera will most likely be inserted in an excavated section of the discharge line midway between the west side of Building 03-80 and the west gate culvert. This survey will attempt to determine the condition of the line and the exact location of the discharge point. A three-phase approach will be used to investigate the UDP:

\section{Phase I}

- For the purpose of verifying the location of the discharge line or accessing an entry point for the video system, excavate trenches perpendicular to the expected orientation of the discharge line in the following proposed locations (Figure 4-1):

- Between Area 3 west fence and perimeter road

- At expected bend in discharge line near existing loading dock

- At additional locations if required due to breaks in discharge line

- Use video survey, if possible, to inspect discharge line condition and locate discharge point

\section{Phase II}

- Collect soil samples from $0.3 \mathrm{~m}$ and $1.2 \mathrm{~m}$ (1 and $4 \mathrm{ft})$ bgs within the wash at the following proposed locations (Figure 4-1):

- Expected UDP location (south end of culvert)

- North end of culvert

- $15 \mathrm{~m}$ and $30 \mathrm{~m}$ (50 and $100 \mathrm{ft})$ south of UDP 


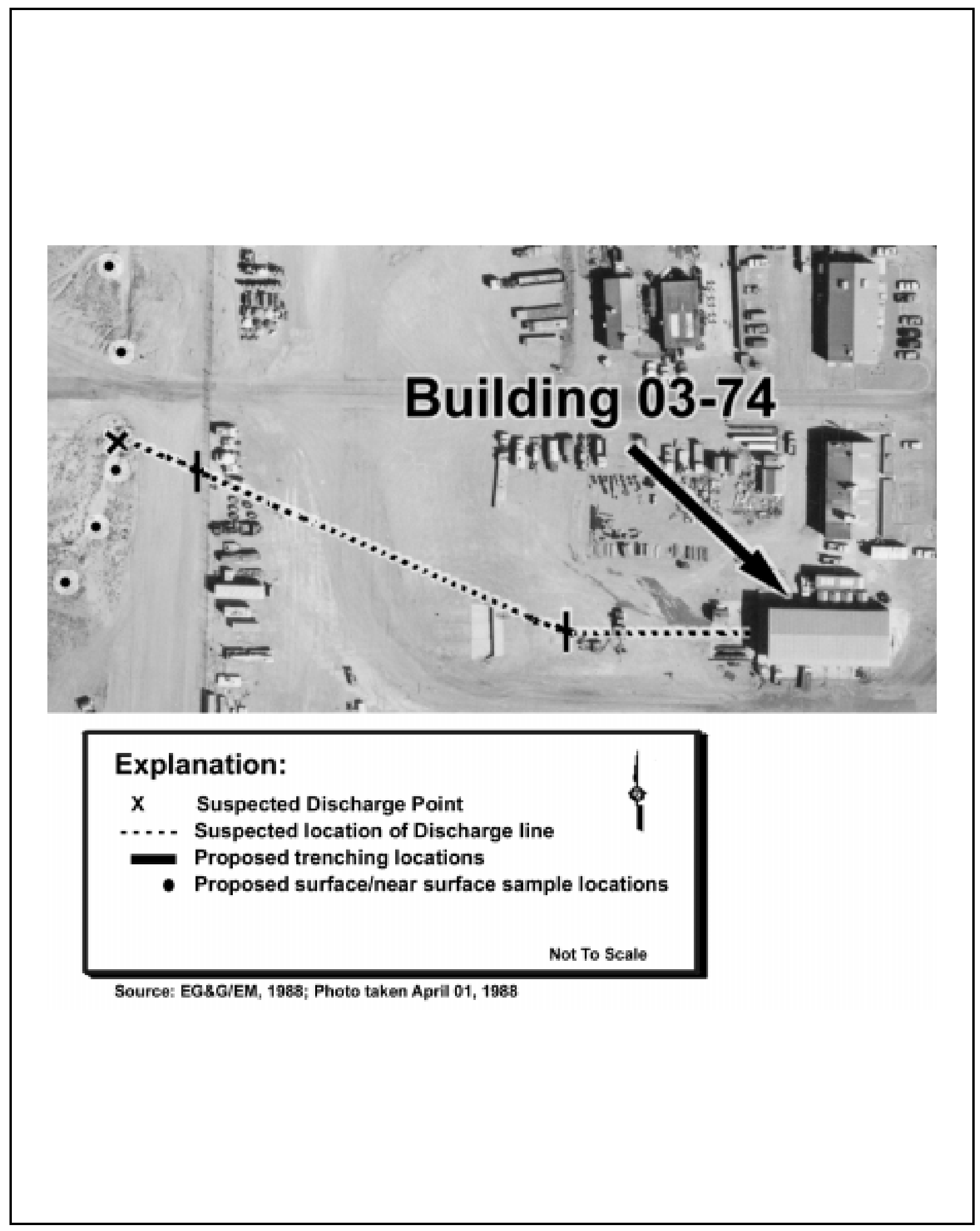

Figure 4-1

Proposed Trenching and Sampling Locations for the Heavy Duty Shop UDPs 
- $30 \mathrm{~m}$ and $60 \mathrm{~m}(100$ and $200 \mathrm{ft})$ north of UDP

- If required, collect step-out samples in the same manner as the initial surface samples to define the lateral extent of surface contamination.

\section{Phase III}

- Drill borehole at the UDP location to $12 \mathrm{~m}(40 \mathrm{ft}) \mathrm{bgs}$

- Field screen and sample every $1.5 \mathrm{~m} \mathrm{(5 \textrm {ft } )}$

- Drill stepout borings in a 4.5-m (15-ft) radius pattern from the UDP if field screening levels are exceeded.

- Additional stepout borings may be drilled as required

\subsubsection{CAU 406, UPS UDP, CAS 03-51-003-0358}

A video camera survey will be attempted on the discharge lines associated with the UPS UDPs. The floor drains within Building 03-58 will be the initial insertion point of the camera to determine if the drain lines have been rerouted to the consolidated sewer system. If so, the camera will most likely be reinserted in an excavated section of the discharge line (if located) midway between the west side of Building 03-58 and the suspected location of the UDPs. This survey will attempt to determine the exact location of the discharge points. The investigation of these UDPs will use a two-phase approach:

\section{Phase I}

- Use video survey to locate the discharge points, if possible.

- Excavate three trenches on the west side of the UPS building (Figure 4-2)

- Two trenches parallel to discharge lines

- One trench perpendicular to and across the two previous trenches at assumed UDP location

- Collect soil samples from excavations at UDP locations, or assumed UDP locations if UDP features are not identified. 


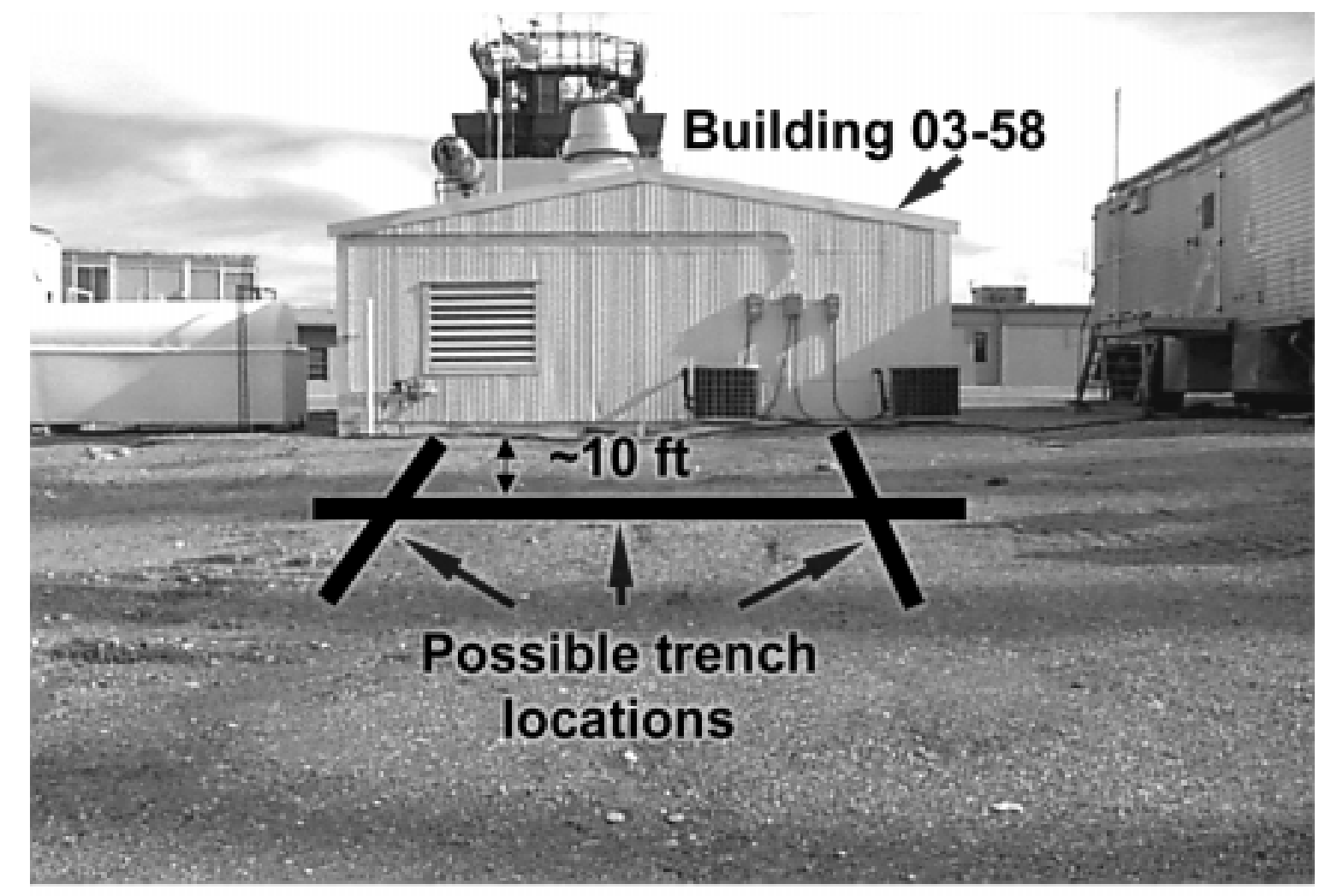

Explanation:

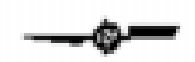

Proposed trench location

Not To Scale

Source: IT, 1998; Photograph taken January 13, 1998

Figure 4-2

Proposed Trenching Locations for the UPS Building UDPs 


\section{Phase II}

The second phase of this investigation will be initiated only if COPCs are detected above field screening levels at the maximum excavation depth of the backhoe (i.e., $3 \mathrm{~m}$ [10 ft]). Based on the conceptual site model, this is not expected.

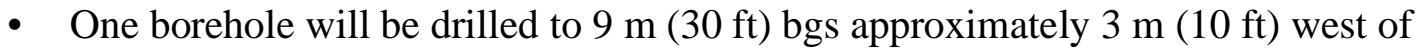
Building 03-58 near the approximate location of the two UDPs, or based on the results of the excavation activities in phase one.

- $\quad$ Field screen and sample every $1.5 \mathrm{~m}(5 \mathrm{ft})$

- Drill stepout borings in a 4.5-m (15-ft) radius pattern if field screening results exceed screening levels.

\subsubsection{CAU 429, Area 3 Photoshop UDPs, CAS 03-51-001-0355}

The location of the two UDPs and the nature of contamination in this CAS is well defined; therefore, a video survey of the discharge lines is not planned. This site will be investigated in a three-phase approach:

\section{Phase I}

- Excavate with backhoe to verify the discharge line is capped or rerouted and no longer discharges to the UDPs (Figure 4-3).

- Excavate with backhoe between the two UDPs to verify the existence and depth of the overflow pipe (Figure 4-3).

\section{Phase II}

- Collect samples using the direct-push method from $0.3 \mathrm{~m}$ and $0.9 \mathrm{~m}$ (1 and $3 \mathrm{ft}$ ) bgs in a 7.6-m $(25-\mathrm{ft})$ radius triangular pattern centered on the primary UDP to detect potential surface or near-surface contamination associated with overflow (Figure 4-3).

- If required, collect step-out samples in the same manner as the initial surface samples to define the lateral extent of surface contamination. 


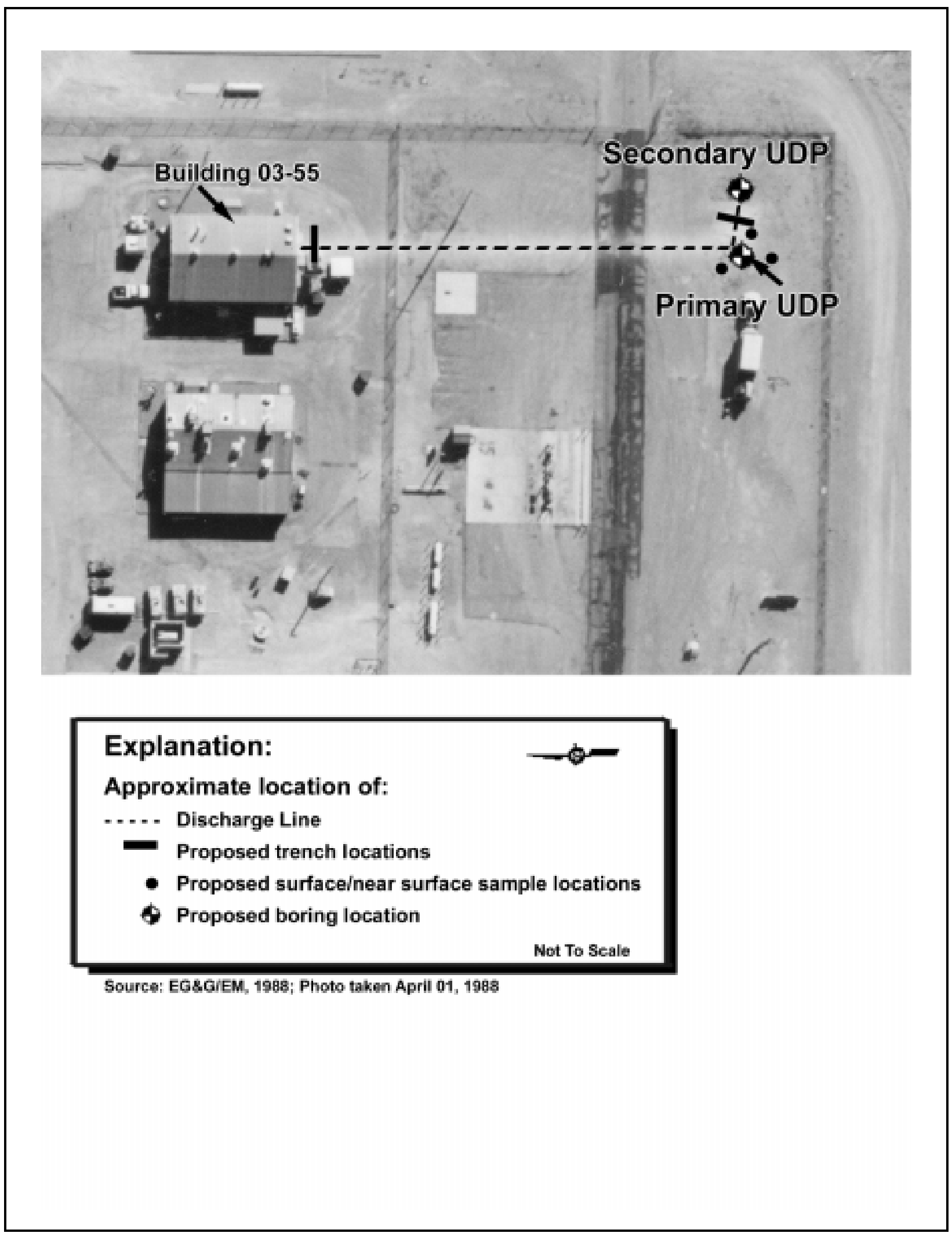

Figure 4-3

Proposed Trenching and Sampling Locations for the Area 3 Photoshop UDPs 


\section{Phase III}

- Drill borehole through primary UDP to $12 \mathrm{~m}(40 \mathrm{ft}) \mathrm{bgs}$

- Field screen and sample every $1.5 \mathrm{~m}(5 \mathrm{ft})$

- Drill stepout borings in a 4.5-m (15-ft) radius pattern from the UDP, if field screening levels are exceeded.

- Additional stepout borings may be drilled as required

- Drill borehole through secondary UDP to $12 \mathrm{~m}(40 \mathrm{ft}) \mathrm{bgs}$

- Field screen and sample every $1.5 \mathrm{~m} \mathrm{(5 \textrm {ft } )}$

- Drill stepout borings in a 4.5-m (15-ft) radius pattern from the UDP if field screening levels are exceeded.

- Additional stepout borings may be drilled as required

\subsubsection{CAU 429, Area 9 Mobile Photo Lab UDPs, CAS 09-51-001-0952}

The location of these UDPs and the nature of contamination is well defined; therefore, a video survey of the discharge lines will not be conducted. This site will be investigated in a two-phase approach:

\section{Phase I}

- To prevent unauthorized discharge of materials to the UDP system, the line from Building 09-52 to the septic tank will be excavated and capped.

- The contents of the septic tank will be sampled.

- Soil samples from the influent and effluent ends of the septic tank will be sampled either through excavation or direct-push methods (Figure 4-4).

\section{Phase II}

- Drill one borehole through each UDP to $12 \mathrm{~m}$ (40 ft) bgs

- Field screen and sample every $1.5 \mathrm{~m} \mathrm{(5 \textrm {ft } )}$ 


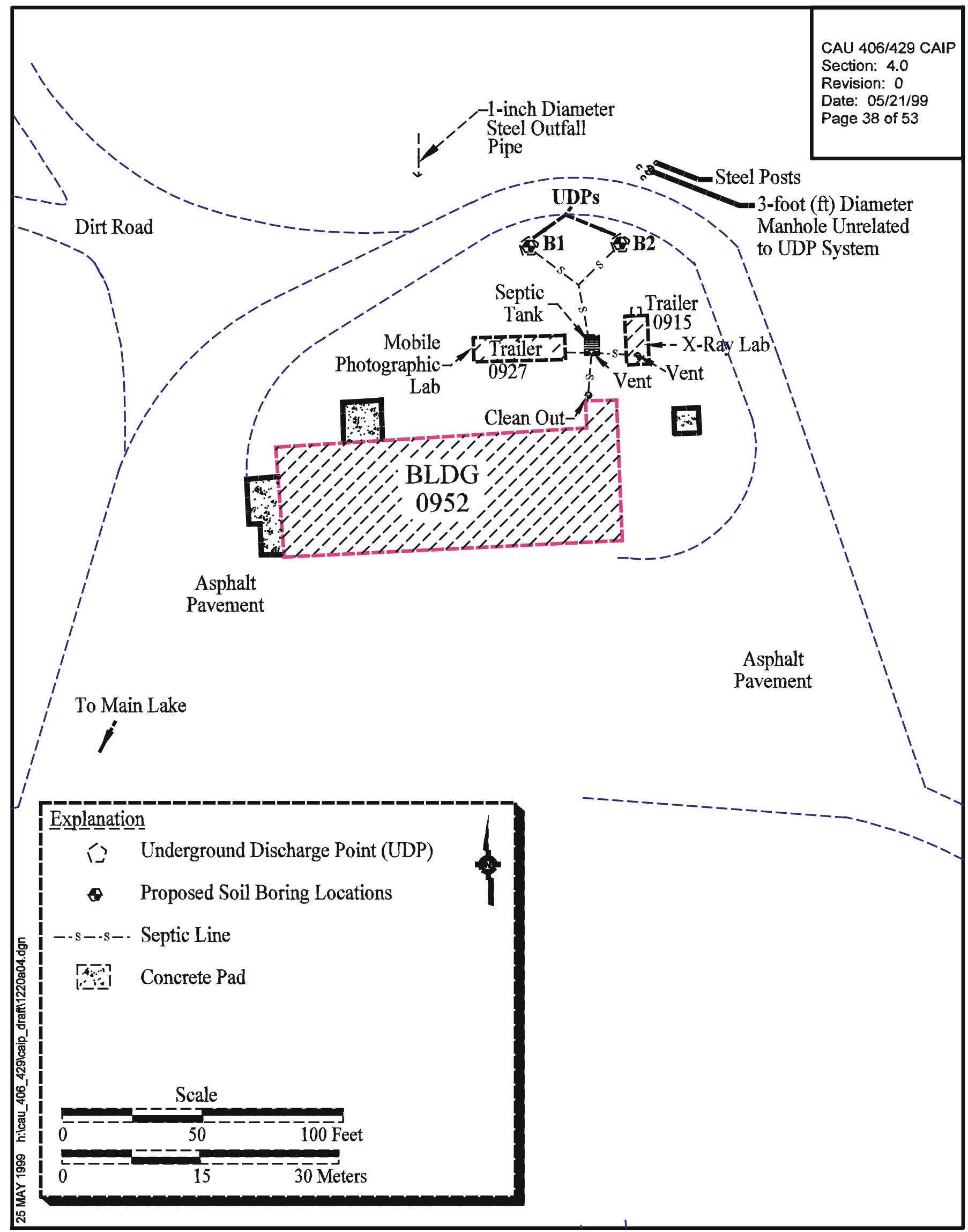

Figure 4-4

Proposed Investigation Areas, Mobile Photoprocessing Lab UDPs Area 9, Tonopah Test Range 
- Drill stepout borings in a $4.5 \mathrm{~m}(15 \mathrm{ft})$ radius pattern around the UDPs if field screening results exceed field screening levels.

- Additional stepout borings may be drilled as required

\subsection{Sampling Criteria}

All sampling activities for CAU 406 and CAU 429 will be conducted in compliance with requirements of the Industrial Sites QAPP (DOE/NV, 1996c) and this CAIP. Subsections 4.4.1 through 4.4.5 provide details on the type of sample collection that will be performed during the field investigation. The CAS-specific details on sampling strategy and proposed sampling locations are provided in Section 4.3. Details of the field screening to be conducted at each CAU/CAS are provided in Section 4.2.5.

Records will be maintained for a visual classification of the soil from boreholes, field-screening measurements, and all other relevant data. Pertinent and required sampling information (e.g., date, time, sample interval) will be documented in accordance with the Industrial Sites QAPP (DOE/NV, 1996c). Approved chain of custody procedures (DOE/NV, 1994a) will be followed to assure sample integrity.

All equipment which contacts soil to be sampled will be decontaminated in accordance with written, approved, and controlled procedures. Core barrels (including direct-push barrels) will be decontaminated prior to each sampling event to minimize the potential for cross-contamination of samples from different locations or depths.

\subsubsection{Environmental Samples}

Environmental samples collected for laboratory analysis will be samples of fresh (unused) media. Samples will be collected with highest priority given to those that will be analyzed for VOCs. When volatilization of COPCs is not a concern, samples will be collected with priority given to those with the shortest hold times prior to analysis. Samples submitted to the laboratory will be analyzed in accordance with Appendix C. 
All surface/near-surface samples collected using the direct-push method will be sent for laboratory analysis. All samples collected from septic system components (i.e., septic tank in CAU 429) will be sent for laboratory analysis. Samples taken from the initial UDP borings will be collected for laboratory analysis based on visual observations (e.g., areas of visible staining) and/or the results of field screening. The interface between the base of the UDP and native soil, if identified, will also be sampled. The two deepest consecutive, nondetect samples for the initial borings will be submitted to the laboratory to bound the vertical extent of contamination and verify field screening readings. In step-out borings (if performed), samples will be collected for laboratory analysis from the highest field-screening interval and the lowest vertical, nondetect interval. If field screening does not detect any contamination in the step-out borings (after drilling to the established minimum depth based on field screening results at the initial UDP boring), the first of the two consecutive samples below field-screening levels will be submitted for confirmation of the nondetect field screening readings.

Discretionary sampling points may also be selected for laboratory analysis based on a visual examination by the Site Supervisor/Geologist. Selection criteria for discretionary samples could include:

- Moist or discolored zones

- Significant changes in soil grain size

- Odor

Proposed analytical parameters were selected based on process and historical knowledge, sampling data, and discussions during the DQO process. The list of CAS-specific analytes for laboratory analyses is stated in Section 3.2 and Section A.3.0 of Appendix A.

\subsubsection{Quality Control Samples}

Quality control samples will be collected as required by the Industrial Sites QAPP (DOE/NV, 1996c). These samples will include trip blanks, equipment blanks, source blanks, field blanks, field duplicates, and matrix spike/matrix spike duplicate (MS/MSD) samples. Except for trip blanks, all QC samples will be analyzed for applicable parameters as listed in Tables A.3-1 through A.3-3 for each CAS. Trip blanks will only be analyzed for VOCs. With the exception of MS/MSD, QC 
samples shall be submitted to the laboratory blind. Additional QC samples may be submitted at the discretion of the Site Supervisor.

\subsubsection{Background Samples}

Background data on RCRA metals and radionuclides have been previously generated for Area 3 and Area 9 during past investigations and will be used to evaluate data in the CADD. No background samples will be collected during this investigation.

\subsubsection{Geotechnical Samples}

In addition to environmental samples, at least one geotechnical sample will be collected from each site to characterize the geologic and hydrologic properties of the soil. Analysis of geotechnical parameters listed in Table 4-1 will be performed by an off-site laboratory. The methods shown are minimum standards, and other equivalent or superior testing methods may be used.

Table 4-1

Geotechnical Analyses

\begin{tabular}{|c|c|}
\hline Analysis & Method \\
\hline Initial moisture content & ASTM $^{a}$ D 2216-92 \\
\hline Dry bulk density & ASTM $^{a}$ D 2937-94 \\
\hline Calculated porosity & EM $^{b}-1110-2-1906$ or MOSA Chp. 18 \\
\hline Saturated hydraulic conductivity & $\begin{array}{c}\text { ASTM }^{a} \text { D 2434-68(74) } \\
\text { MOSA }^{c} \text { Chp. } 28\end{array}$ \\
\hline Unsaturated hydraulic conductivity & van Genuchten $^{d}$ \\
\hline Particle-size distribution & ASTM $^{\mathrm{a}}$ D 422-63(90) \\
\hline Water-release (moisture retention) curve & $\begin{array}{c}\text { MOSA }^{\mathrm{c}} \text { Chp. } 26 \\
\text { ASTM }^{\mathrm{a}} \text { D 2325-68(94) } \\
\text { MOSA }^{\mathrm{c}} \text { Chp. } 24 \\
\text { Karanthanasis and Hajek }\end{array}$ \\
\hline
\end{tabular}

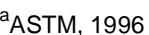

bUSACE, 1970

'MOSA, 1986 (Soil Science Society of America)

dvan Genuchten, 1980

${ }^{\mathrm{e}}$ Karanthanasis and Hajek, 1982 


\subsubsection{Bioassessment Samples}

At least one bioassessment sample will be collected from each site in CAU 406 at the discretion of the Site Supervisor if field screening results detect TPH above the field screening levels. Bioassessment is a series of tests designed to evaluate the physical, chemical, and microbiological characteristics of soil. These tests include determinations of nutrient availability, soil $\mathrm{pH}$, microbial population density, and the ability of the microbial population to grow under enhanced conditions. The data will be used in the evaluation of alternatives in the CADD. 


\subsection{Waste Management}

Management of investigation-derived waste (IDW) will be based on regulatory requirements, field observations, process knowledge, and the results of laboratory analysis of the CAU investigation samples. Decontamination activities will be performed according to approved contractor procedures specified in the contractor field sampling instructions and as appropriate for the COPCs identified for these CAUs.

Waste other than soil such as disposable sampling equipment, personal protective equipment (PPE), and rinsate, is considered potentially contaminated waste only by virtue of contact with potentially contaminated media. Therefore, sampling and analysis of the IDW, separate from analyses of site characterization samples, may not be necessary. However, rinsate or other samples may be taken to support waste management activities (e.g., TCLP silver and isotopic uranium soil samples). The data generated as a result of site characterization and process knowledge will be used whenever possible to assign the appropriate waste type (i.e., sanitary, hazardous, low-level radioactive waste [LLW], or mixed) to the IDW.

No process knowledge has been identified to indicate that any specific "listed" hazardous wastes were released or disposed at the Area 3 or Area 9 photo shops or at the UPS building UDPs. Therefore, if contaminants are identified at these sites, it is likely they would be characteristic rather than listed hazardous wastes.

Process knowledge indicates that listed solvents may have been disposed of via the floor drains at the Heavy Duty Shop. The IDW generated during the investigation of the Heavy Duty Shop UDP will be considered listed waste if either 1,2-dichlorobenzene (ortho-dichlorobenzene) or cresol are identified in associated soil samples. Other contaminants identified at this site, likely would be characteristic rather than listed.

Sanitary, hazardous, radioactive, and/or mixed waste, if generated, will be managed and disposed of in accordance with DOE Orders, U.S. Department of Transportation (DOT) regulations, RCRA regulations, Nevada Revised Statutes (NRS) 1998, and agreements and permits between the DOE and NDEP. No process knowledge indicates radioactive wastes were disposed of in the UDPs other than 
possibly CAS 03-51-002-0374 (Heavy Duty Shop UDP). Depleted uranium has been documented as a COPC for this site. However, based on the process knowledge it is not believed that DU will be present in levels which would require disposal as LLW. Therefore, when the waste is initially generated, the waste will be managed according to hazardous waste requirements until laboratory analyses are received and a final waste determination is made.

\subsection{Waste Minimization}

Corrective action investigation activities have been planned to minimize IDW generation.

Decontamination activities will only use as much water as necessary to decontaminate equipment and personnel to minimize the amount of rinsate generated. Disposable sampling equipment, decontamination rinsate, and PPE will be segregated to the greatest extent possible to minimize the generation of hazardous, radioactive, and/or mixed waste.

\subsection{Potential Waste Streams}

Potentially contaminated wastes generated during the investigation activities may include the following:

- Disposable sampling equipment (e.g., plastic, aluminum foil) and PPE

- Decontamination rinsate

- Soil

- Wastes associated with the use of TPH

Waste will be segregated by waste stream and will be traceable to its source and to associated samples. This information will be recorded in the waste management logbook.

\subsection{Investigation-Derived Waste Management}

Management requirements for sanitary, low-level radioactive, hydrocarbon, hazardous, and mixed waste are discussed further in the following sections. IDW generated will be managed as potentially hazardous waste until laboratory results indicate either the presence or absence of RCRA regulated constituents. 


\subsubsection{Sanitary Wastes}

Sanitary wastes not directly associated with sampling activities typically consist of plastic, food, and paper products. This waste will be contained in plastic bags and will be transported to an approved solid waste management unit.

\subsubsection{Low-Level Radioactive Waste}

Radiological COPCs other than DU are not anticipated at these CAUs. Radiological controls, including the requirements detailed in this subsection, will not be instituted unless field-screening results exceed field-screening levels specified in Section 3.3.1. If field-screening levels are exceeded, the waste will be managed as LLW pending analysis. If LLW is generated, it will be managed in accordance with the contractor specific waste certification program plan, DOE Orders, and the Nevada Test Site Waste Acceptance Criteria (NTSWAC) (DOE/NV, 1997).

All drums will be locked or fitted with tamper-indicating devices (TIDs) and labeled "Radioactive Material Pending Analysis." The drums will be staged at a designated Radioactive Controlled Area pending disposal. If field screening results indicate that activity levels meet the criteria for placement in a Radioactive Materials Area, one will be established.

The PPE and disposable sampling equipment will be placed in clear plastic bags marked with the generation date and an associated sample location and/or sample number. The bags will be tagged with a contractor-specific waste tracking tag and logged in the contractor-specific waste management logbook.

Soil generated during investigation activities that is not returned to the origin of removal will be collected in drums containing 6 mil liners. Drums used to contain soil shall be inspected prior to use. If a drum is damaged, cannot be locked, or cannot accommodate a TID, it shall not be used. Absorbent Stergo ${ }^{\mathrm{TM}}$ pads shall be added to drums of radiologically contaminated soil. Contractor-specific waste tracking tags shall be used and may be attached to the inside liner, the exterior of the drums, or marked with the drum's unique identification number, and stored with the contractor-specific logbook. The sample number must be placed on each tracking tag. Drum inspection and absorbent addition shall be documented on the appropriate form. 
Rinsate may be analyzed separately to determine final disposition. If rinsate is categorized as low-level waste on the basis of container-specific sampling or other methods, it will be solidified prior to NTSWAC certification activities.

\subsubsection{Hydrocarbon}

The action level for soil contaminated with hydrocarbons is $100 \mathrm{mg} / \mathrm{kg}$ in the State of Nevada (NAC, 1998b). Soils and associated IDW with TPH levels above $100 \mathrm{mg} / \mathrm{kg}$ which contains RCRA regulated constituents below regulatory limits shall be managed as hydrocarbon waste and shall be disposed of in accordance with all applicable regulations.

\subsubsection{Hazardous Waste}

Suspected hazardous waste will be managed in accordance with RCRA and State of Nevada hazardous waste management regulations interpreted as follows. Suspected hazardous waste will be placed in 55-gallon drums that meet DOT specifications in accordance with 49 Code of Federal Regulations (CFR) 172 (CFR, 1998d) which will be locked and fitted with TIDs. The IDW containers will comply with 40 CFR 265.1087 (CFR, 1998c), and drums shall be compatible with the waste in accordance with the requirements of 40 CFR 265.172 (CFR, 1998c). No incompatible wastes are expected to be generated; however, incompatible waste encountered in the field will be managed in accordance with 40 CFR 265.177 (CFR, 1998c) (i.e., shall not be placed in the same container and shall be separated so that in the event of a spill, leak, or release, incompatible wastes shall not contact one another). Drums shall be handled and inspected in accordance with the requirements of 40 CFR 265.173 and 174, respectively (CFR, 1998c).

Hazardous waste shall be characterized in accordance with the requirements of 40 CFR 261 (CFR, 1998a). Characterization will be based on laboratory results and process knowledge. Drums containing IDW pending characterization will be marked with the words "Hazardous Waste Pending Analysis" until its regulatory status can be determined through interpretation and evaluation of laboratory results. The IDW shall be traceable to its source and to associated samples. Traceability shall be maintained by assigning a unique waste tracking number to each container and by maintaining records that trace the IDW back to the samples. After receipt of analytical results, if 
hazardous waste is identified, it will be labeled and marked in accordance with the requirements of 40 CFR 262.31 and 40 CFR 262.32 (CFR, 1998b) and State of Nevada requirements.

Hazardous waste, if identified, will be evaluated against the Nevada Test Site Performance Objectives for Certification of Nonradioactive Hazardous Waste (BN, 1995).

Hazardous waste management methods including the establishment of Satellite Accumulation Areas or a 90-day Hazardous Waste Accumulation Area (HWAA) will be employed to temporarily accumulate IDW pending characterization. These methods will be appropriate for the amount of waste being accumulated and in compliance with applicable State of Nevada and federal requirements.

Suspected hazardous waste will be accumulated in a HWAA at or near the site of generation for up to 90 days in accordance with 40 CFR 262.34 (CFR, 1998b). Prior to or on the ninetieth day of accumulation as specified in 40 CFR 262.34 (a) (CFR, 1998b), hazardous waste will be shipped by a licensed/permitted hazardous waste transporter to a permitted treatment, storage, and disposal facility. If hazardous waste must remain on-site for longer than 90 days due to unforeseen, temporary, and uncontrollable circumstances, a letter requesting an extension for up to 30 days will be sent to the NDEP in accordance with 40 CFR Part 262.34 (CFR, 1998b). A copy of the uniform hazardous waste manifest shall be provided to the State of Nevada.

\subsubsection{Mixed Wastes}

No mixed waste is expected to be generated at this site. However, if mixed waste is generated, the waste shall be managed in accordance with 40 CFR 262 (CFR, 1998b) and State of Nevada NAC 444 (NAC, 1998a). These regulations, and the DOE requirements for radioactive waste are interpreted as follows. Where there is a conflict in regulations or requirements, the most stringent shall apply. For example, the 90-day accumulation time limit and weekly inspections per RCRA regulations will be applied to mixed waste even though they are not required for radioactive waste. Conversely, while RCRA does not require documented traceability, the NTSWAC for LLW does; therefore, traceability shall be documented. 
In general, mixed waste shall be managed in the same manner as hazardous waste, with added mandatory radioactive waste management program requirements. Suspected mixed waste will be managed in accordance with applicable regulations and requirements and will be marked with the words "Hazardous Waste Pending Analysis" pending characterization and confirmation of its regulatory status. However, once the waste determination is made, or the RCRA 90-day time requirement draws to an end, mixed waste shall be transported via a licensed hazardous waste hauler to the Nevada Test Site transuranic waste storage pad for storage pending treatment or disposal. Mixed waste with hazardous waste constituents below land disposal restrictions may be disposed of at the Area 5 Radioactive Waste Management Site.

Mixed waste not meeting land disposal restrictions will require development of a treatment plan under the requirements of the Mutual Consent Order between the DOE and the State of Nevada (NDEP, 1995). NDEP will be notified if any mixed waste is generated. 


\subsection{Duration and Records Availability}

\subsection{Duration}

After the submittal of the CAIP to NDEP (FFACO milestone date of June 30, 1999), the following is a tentative schedule of activities (in calendar days):

- Day 0: Preparation for field work will begin.

- Day 60: The field work, including field screening and sampling, will begin. Samples will be shipped to meet laboratory holding times.

- Day 110: The field work will be completed.

- Day 185: The quality-assured laboratory analytical sample data will be available for review.

- $\quad$ The FFACO date for the CADD is March 31, 2000.

\subsection{Records Availability}

This document is available in the DOE public reading rooms located in Las Vegas and Carson City, Nevada, or by contacting the DOE project manager. The NDEP maintains the official Administrative Record for all activities conducted under the auspices of the FFACO. 


\subsection{References}

ASTM, see American Society for Testing and Materials.

American Society for Testing and Materials. 1996. Section 04.08 and 04.09, "Construction." In Annual Book of ASTM Standards. Philadelphia, PA.

Atlan-Tech. 1992. Environmental Monitoring Report for the Proposed Ward Valley California LLRW Facility. Rosewall, GA: Atlan-Tech Inc.

BN, see Bechtel Nevada.

Bechtel Nevada. 1995. Nevada Test Site Performance Objective for Certification of Nonradioactive Hazardous Waste, Rev. 0. Las Vegas, NV.

CFR, see Code of Federal Regulations.

Code of Federal Regulations. 1998a. 40 CFR Part 261, "Identification and List of Hazardous Waste." Washington, DC: U.S. Government Printing Office.

Code of Federal Regulations. 1998b. 40 CFR Part 262, "Standards Applicable to Generators of Hazardous Waste.” Washington, DC: U.S. Government Printing Office.

Code of Federal Regulations. 1998c. 40 CFR Part 265, "Interim Status Standards for Owners and Operators of Hazardous Waste Treatment, Storage, and Disposal Facilities." Washington, DC: U.S. Government Printing Office.

Code of Federal Regulations. 1998d. 49 CFR Part 172, "Hazardous Materials Table, Special Provisions, Hazardous Materials Communications, Emergency Response Information, and Training Requirements.” Washington, DC: U.S. Government Printing Office.

DOE/NV, see U.S. Department of Energy, Nevada Operations Office.

EG\&G/EM, see EG\&G Energy Measurements.

EG\&G Energy Measurements. 1988. Photo Number 5957-23, 01 April. Nellis Air Force Base, NV: BN Remote Sensing Laboratory Photo Library.

EPA, see U.S. Environmental Protection Agency.

FFACO, see Federal Facility Agreement and Consent Order. 
Federal Facility Agreement and Consent Order. 1996 (as amended). Agreed to by the State of Nevada, the U.S. Department of Energy, and the U.S. Department of Defense.

IT Corporation. 1994. Sandia National Laboratories/New Mexico, Septic Tank Monitoring Report, Tonopah Test Range and Nevada Test Site. Tonopah, NV: Sandia National Laboratories.

IT Corporation. 1998. Digital photograph "Image 01" of the UPS Building 03-58 in Area 3 at TTR, 13 January. Las Vegas, NV: IT Digital Photograph Database.

Karanthanasis, A.D., and B.F. Hajek. 1982. "Quantitative Evaluation of Water Absorption on Soil Clays.” In Soil Science Society of America Journal, 46: 1321-1325.

Karas, P. 1993. Memo to G. West (SNL) entitled, "Environmental Restoration Interview Notes," 30 July. Tonopah, NV: Sandia National Laboratories.

McArthur, R.D., and F.L. Miller. 1989. Off-Site Radiation Exposure Review Project (ORERP), Phase II Soil Program, DOE/NV/10384-23. Las Vegas, NV: Desert Research Institute.

MOSA, see Soil Science Society of America.

NAC, see Nevada Administrative Code.

NDEP, see Nevada Division of Environmental Protection.

NRC, see U.S. Nuclear Regulatory Commission.

NRS, see Nevada Revised Statutes.

Nevada Administrative Code. 1998a. NAC 444, "Sanitation." Carson City, NV: Nevada Division of Environmental Protection.

Nevada Administrative Code. 1998b. NAC 445A.2272, "Water Controls." Carson City, NV:

Nevada Division of Environmental Protection.

Nevada Division of Environmental Protection. 1995. "Mutual Consent Agreement Between the State of Nevada and the Department of Energy for the Storage of Low-Level Land Disposal Restricted Mixed Waste." Transmittal from P. Liebendorfer (NDEP) to D. Elle (DOE/NV), 7 June. Carson City, NV.

Nevada Revised Statutes. 1998. NRS459.9973, 459.9975, and 459.9977, "Hazardous Materials." Carson City, NV: Nevada Division of Environmental Protection.

Phelan. J.M. 1988. Memo entitled, "Environmental Restoration Program Status for Satellite Facilities," 17 May. Albuquerque, NM: Sandia National Laboratories. 
Quas. J. 1993. Record of Telecon with E. Mignardot (ITLV) regarding information pertaining to the UPS Building 03-58 UDPs at TTR, 28 July. Las Vegas, NV: IT Corporation.

Quas, J. 1998. Record of Telecon with M. England (SAIC) regarding information pertaining to the UPS Building 03-58 UDPs at TTR, 3 April. Tonopah, NV.

SNL, see Sandia National Laboratories.

Samuelson. T. 1998. Record of Telecon with J. Markowsky (SAIC) regarding operations at the Area 9 Building 0952, 22 April. Las Vegas, NV.

Sandia National Laboratories. 1998. In-Situ Closure Plan, Area 3 UPS Building, Tonopah Test Range, Tonopah, Nevada. Albuquerque, NM.

Schirber, A.L. 1984. Letter to G.J. Smith (SNL) entitled, "Environmental Audit of TTR on July 6, 1984," 10 October. Albuquerque, NM: Sandia National Laboratories.

Smith, R. 1998. Record of Telecon with J. Markowsky (SAIC) regarding information pertaining to the Heavy Duty Shop UDP, 6 May. Las Vegas, NV: IT Corporation.

Soil Science Society of America. 1986. Methods of Soil Analysis, 2nd Edition, Part 1. Madison, WI.

USACE, see U.S. Army Corps of Engineers.

U.S. Army Corps of Engineers. 1970. "Laboratory Soils Testing.” In Engineering Manual 1110-2-1906, Appendix II. Washington, DC.

U.S. Department of Energy, Nevada Operations Office. 1994a. ERD-05-201, "Chain of Custody," Rev. 0. Las Vegas, NV.

U.S. Department of Energy, Nevada Operations Office. 1994b. Project Management Plan, Rev. 0. Las Vegas, NV.

U.S. Department of Energy, Nevada Operations Office. 1996a. Corrective Action Unit Work Plan, Tonopah Test Range, Nevada, Rev. 0, DOE/NV--443. Las Vegas, NV.

U.S. Department of Energy, Nevada Operations Office. 1996b. Final Environmental Impact Statement for the Nevada Test Site and Off-Site Locations in the State of Nevada, DOE/EIS 0243. Las Vegas, NV.

U.S. Department of Energy, Nevada Operations Office. 1996c. Industrial Sites Quality Assurance Project Plan, Nevada Test Site, Nevada, Rev. 1, DOE/NV--372. Las Vegas, NV. 
U.S. Department of Energy, Nevada Operations Office. 1997. Nevada Test Site Waste Acceptance Criteria, Rev. 1. Las Vegas, NV.

U.S. Department of Energy, Nevada Operations Office. 1998. Environmental Restoration Project Health and Safety Plan, Rev. 3. Las Vegas, NV.

U.S. Environmental Protection Agency. 1994. Guidance for the Data Quality Objectives Process, EPA QA/G-4. Washington, DC.

U.S. Environmental Protection Agency. 1998. Memo from S.J. Smucker to table mailing list regarding Region 9 Preliminary Remediation Goals (PRGs), 1 August. San Francisco, CA.

U.S. Nuclear Regulatory Commission. 1997. Multi-Agency Radiation Survey and Site Investigation Manual (MARSSIM), NUREG-1575/EPA 402-R-97-016. Prepared by the NRC, EPA, DOE, and DoD. Washington DC: U.S. Government Printing Office.

van Genuchten, M. 1980. "A Closed Form Equation for Predicting the Hydraulic Conductivity of Unsaturated Soils.” In Soil Science Society of America Journal, 44: 892-898. El Cerrito, CA.

West, G. 1998. Record of Telecon with J. Markowsky (SAIC) regarding information pertaining to the Heavy Duty Shop UDP, 6 May. Las Vegas, NV: IT Corporation. 


\section{Appendix A}

\section{Data Quality Objectives}




\section{A.1.0 Introduction}

\section{A.1.1 Problem Statement}

Potentially hazardous wastes were discharged to the UDP systems that comprise CAU 406

(CASs 03-51-002-0374 and 03-51-003-0358) and CAU 429 (CASs 03-51-001-0355 and

09-51-001-0952). Existing information about the nature and extent of contamination is insufficient to evaluate and select preferred corrective actions for these sites.

These CAUs will be investigated based on DQOs developed by representatives of NDEP and DOE/NV. This investigation will determine if COPCs are present and if concentrations exceed regulatory levels in soils surrounding the UDPs. If COPCs are detected, the lateral and vertical extent of contamination will be delineated. Data adequate to close the site under NDEP, RCRA, and DOE requirements will be collected.

\section{A.1.2 DQO Kickoff Meeting}

Table A.1-1 lists the participants present at the FFACO-required DQO Kickoff Meeting and any subsequent meetings. The goal of the DQO process is to establish the quantity and quality of environmental data required to support corrective action decisions for the CAUs. The process ensures that the information collected will provide sufficient and reliable information to identify, evaluate, and technically defend the chosen corrective action. Unless otherwise required by the results of this DQO and stated in the CAIP, this investigation will adhere to the Industrial Sites QAPP (DOE/NV, 1996b). 
Table A.1-1

\section{DQO Kickoff Meeting Participants}

\begin{tabular}{|c|c|c|c|}
\hline \multirow{2}{*}{ Participant } & \multirow{2}{*}{ Affiliation } & Meeting Date & Meeting Date \\
\hline & & $\begin{array}{c}\text { Kickoff Meeting } \\
\text { August 4, } 1998\end{array}$ & February 25, 1999 \\
\hline Steve Adams & IT & $X$ & \\
\hline Rob Boehlecke & SAIC & $X$ & \\
\hline Kevin Cabble & DOE & $X$ & $X$ \\
\hline Mark DiStefano & IT & $X$ & \\
\hline Syl Hersh & IT & $X$ & \\
\hline Jodi Markowsky & SAIC & $X$ & \\
\hline Mike McKinnon & NDEP & $X$ & \\
\hline Jason Moore & SAIC & $\mathrm{X}$ & $X$ \\
\hline Greg Raab & NDEP & $X$ & \\
\hline Cheryl Rodriquez & IT & $X$ & \\
\hline Jeff Smith & $\mathrm{BN}$ & $X$ & \\
\hline Mary Todd & SAIC & $X$ & \\
\hline Jeanne Wightman & Mactec & $\mathrm{X}$ & \\
\hline Dawn Arnold & SAIC & & $X$ \\
\hline Shannon Parsons & $\mathrm{BN}$ & & $X$ \\
\hline
\end{tabular}

IT - IT Corporation

SAIC - Science Applications International Corporation

DOE - U.S. Department of Energy

NDEP - Nevada Division of Environmental Protection

BN - Bechtel Nevada

Mactec - Management Analysis Company Technical 


\section{A.2.0 Conceptual Model}

Before the early 1990s, UDPs were used to dispose of liquid waste related to several operations at the TTR, Nevada. The UDPs are typically subgrade shallow dry wells or excavations filled with gravel. Waste liquids were discharged to the UDPs via distribution lines and allowed to percolate into the surrounding soil for disposal. Section 2.0 of the CAIP describes the UDPs, their operational histories, waste inventories, release information, and investigative backgrounds.

The conceptual model for the CAU 406 and CAU 429 UDPs is provided in Table A.2-1. 
Table A.2-1

\section{Conceptual Site Model}

(Page 1 of 3 )

\begin{tabular}{|c|c|c|}
\hline $\begin{array}{l}\text { Conceptual Model } \\
\text { Element }\end{array}$ & Description & Source \\
\hline \multirow{6}{*}{$\begin{array}{l}\text { Heavy Duty Shop UDP } \\
\text { (CAS 03-51-002-0374) }\end{array}$} & $\begin{array}{l}\text { Exact location uncertain, but most likely at south end of Area } \\
3 \text { West Gate culvert }\end{array}$ & $\begin{array}{l}\text { DOE/NV, 1996a; SNL, } \\
\text { 1985; Quas, 1998a; and } \\
\text { Process knowledge }\end{array}$ \\
\hline & $\begin{array}{l}\text { Likely a gravel-filled excavation that received effluent from } \\
\text { the Building 03-74 floor drains and steam cleaning pad } \\
\text { drains; gravel trench was reportedly "mucked out" } \\
\text { periodically and the resultant contaminated fill material } \\
\text { disposed in Area } 3 \text { Landfill(s) }\end{array}$ & Quas, 1998a \\
\hline & $\begin{array}{l}\text { Heavy Duty Shop UDP operated from } 1981 \text { or } 1983 \text { to } \\
\text { around } 1985 \text { or } 1988\end{array}$ & $\begin{array}{c}\text { Quas, 1998a; } \\
\text { SNL, 1992; and } \\
\text { Process knowledge }\end{array}$ \\
\hline & $\begin{array}{l}\text { May have received antifreeze, petroleum products, hydraulic } \\
\text { fluids, solvents, metals, and corrosive chemicals washed off } \\
\text { shop floor or dislodged during equipment cleaning }\end{array}$ & $\begin{array}{l}\text { DOE/NV, 1996a; } \\
\text { Atencio, 1994; and } \\
\text { Quas, 1998a }\end{array}$ \\
\hline & $\begin{array}{l}\text { May have received radioactive material derived from washing } \\
\text { trucks that transported test units containing depleted uranium } \\
\text { components }\end{array}$ & $\begin{array}{l}\text { Smith, 1998; } \\
\text { West, } 1998\end{array}$ \\
\hline & $\begin{array}{l}\text { Volumes of water and COPCs disposed of through the UDP } \\
\text { system are unknown; relatively large amounts of water and } \\
\text { relatively small amounts of COPCs were discharged }\end{array}$ & Process knowledge \\
\hline \multirow{5}{*}{$\begin{array}{l}\text { UPS Building UDPs } \\
\text { (CAS 03-51-003-0358) }\end{array}$} & Two UDPs located approximately $10 \mathrm{ft}$ west of Building 03-58 & $\begin{array}{c}\text { Quas, 1993; } \\
\text { DOE/NV, 1996a }\end{array}$ \\
\hline & $\begin{array}{l}\text { UDPs probably constructed from subgrade gravel filled } \\
55-\text { gal drums, possibly unlined gravel pits; features may have } \\
\text { been removed during unrelated historical diesel remediation }\end{array}$ & $\begin{array}{l}\text { Quas, 1998a; } \\
\text { Quas, } 1993\end{array}$ \\
\hline & $\begin{array}{l}\text { May have received trace amounts of waste from floor drains } \\
\text { located in Building 03-58; however, no evidence for } \\
\text { intentional routine disposal through these floor drains. While } \\
\text { some waste (i.e., drips, leaks, spills) was washed down the } \\
\text { floor drains, all routine maintenance wastes (i.e., oil changes) } \\
\text { were transported to maintenance shops for disposal }\end{array}$ & $\begin{array}{l}\text { SNL, 1990-93; } \\
\text { Quas, 1998b }\end{array}$ \\
\hline & $\begin{array}{l}\text { May have received trace amounts of diesel fuel, motor oil, } \\
\text { and antifreeze }\end{array}$ & Quas, 1998b; IT 1994a \\
\hline & $\begin{array}{l}\text { At least two accidental releases of diesel fuel occurred at the } \\
\text { surface; most contaminated soil was removed. } \\
\text { Distinguishing between diesel related to the UDP system and } \\
\text { diesel remaining after the surface spills clean up operations } \\
\text { will be difficult; known diesel-contaminated soil remains } \\
\text { under Building 03-58 }\end{array}$ & $\begin{array}{l}\text { Quas, 1993; DOE/NV, } \\
\text { 1996a; Forston, 1998; } \\
\text { and SNL, } 1998\end{array}$ \\
\hline
\end{tabular}


Table A.2-1

\section{Conceptual Site Model}

(Page 2 of 3 )

\begin{tabular}{|c|c|c|}
\hline $\begin{array}{l}\text { Conceptual Model } \\
\text { Element }\end{array}$ & Description & Source \\
\hline \multirow{7}{*}{$\begin{array}{l}\text { Area } 3 \text { Photoprocessing } \\
\text { Lab (CAS } \\
03-51-001-0355)\end{array}$} & $\begin{array}{l}\text { Primary UDP approximately } 240 \mathrm{ft} \text { south of Building } 03-55 . \\
\text { Secondary UDP subsequently installed } 30 \mathrm{ft} \text { southeast of } \\
\text { primary UDP }\end{array}$ & AEC, 1964; SNL, 1989 \\
\hline & $\begin{array}{l}\text { Both UDPs constructed from } 4 \text {-ft diameter, } 10 \text {-ft deep vertical } \\
\text { steel culvert filled with gravel }\end{array}$ & $\begin{array}{l}\text { Quas, 1994; } \\
\text { DOE/NV, 1996a }\end{array}$ \\
\hline & $\begin{array}{l}\text { Primary UDP installed in 1964, but secondary UDP } \\
\text { installation date is unknown. Both units operated until } \\
\text { approximately } 1989\end{array}$ & AEC, 1964; SNL, 1989 \\
\hline & $\begin{array}{l}\text { Received photoprocessing chemicals from color and black } \\
\text { and white film development, including silver nitrate, acids, } \\
\text { caustics, corrosives, and solvents }\end{array}$ & $\begin{array}{l}\text { Phelan, 1988a; } \\
\text { Schirber, } 1984\end{array}$ \\
\hline & Silver recovery system installed sometime after 1987 & $\begin{array}{l}\text { Blackburn, 1998; } \\
\text { SNL 1987; preliminary } \\
\text { assessment notes }\end{array}$ \\
\hline & $\begin{array}{l}\text { Major COPC is silver; soils probably buffered other } \\
\text { contaminants }\end{array}$ & Process knowledge \\
\hline & $\begin{array}{l}\text { May have received as much as } 250,000 \text { gallons of effluent } \\
\text { per year; rough estimate of typical chemical/water mixture is } \\
0.1 \text { gram per } 100 \text { gallons of water }\end{array}$ & $\begin{array}{l}\text { Phelan, 1988b; Smith, } \\
\text { 1994b }\end{array}$ \\
\hline \multirow{7}{*}{$\begin{array}{l}\text { Area } 9 \text { Mobile Photo } \\
\text { Labs (CAS } \\
09-51-001-0952)\end{array}$} & $\begin{array}{l}\text { Two UDPs and septic tank associated with septic system } \\
\text { installed for Building } 09-52 \text { restroom; located near northeast } \\
\text { corner of Building 09-52 }\end{array}$ & SNL, $1982 a$ and $b$ \\
\hline & $\begin{array}{l}\text { At the surface, the UDPs are } 3-\mathrm{ft} \text { by } 3-\mathrm{ft} \text { square excavations } \\
\text { lined with concrete blocks and filled with gravel. The UDPs } \\
\text { are approximately } 10 \mathrm{ft} \text { deep }\end{array}$ & $\begin{array}{l}\text { DOE/NV, 1996a; } \\
\text { SNL, 1982b }\end{array}$ \\
\hline & $\begin{array}{l}\text { X-ray radiography film processing waste disposed of from } \\
\text { early } 1980 \text { s to early } 1990 \text { s. }\end{array}$ & $\begin{array}{l}\text { Smith, 1998; Bull, 1998; } \\
\text { DOE/NV, 1996a }\end{array}$ \\
\hline & $\begin{array}{l}\text { Received low concentrations of silver and photoprocessing } \\
\text { chemicals including acids, bases, and corrosives }\end{array}$ & Smith, 1994a \\
\hline & $\begin{array}{l}\text { Silver from X-ray radiography film processing is major COPC. } \\
\text { According to sampling results, historical records and } \\
\text { personnel interviews, no other potentially hazardous or } \\
\text { radioactive contaminants were disposed of in this system }\end{array}$ & $\begin{array}{l}\text { IT, 1994b; Samuelson, } \\
\text { 1998; and process } \\
\text { knowledge }\end{array}$ \\
\hline & $\begin{array}{l}\text { Total volume and concentration of photoprocessing } \\
\text { chemicals used unknown }\end{array}$ & Smith, 1994b \\
\hline & $\begin{array}{l}\text { No process waste associated with Building } 09-52 \text { electronics } \\
\text { shop activities were disposed of through the bathroom drains. } \\
\text { General meetings for explosives work and electronic workups } \\
\text { for explosive components are performed in this building }\end{array}$ & $\begin{array}{l}\text { Samuelson, 1998; } \\
\text { Fahrenhorst, 1998a } \\
\text { and b }\end{array}$ \\
\hline
\end{tabular}




\section{Table A.2-1 \\ Conceptual Site Model}

(Page 3 of 3 )

\begin{tabular}{|c|c|c|}
\hline $\begin{array}{l}\text { Conceptual Model } \\
\text { Element }\end{array}$ & Description & Source \\
\hline \multirow{3}{*}{$\begin{array}{l}\text { Lateral extent of } \\
\text { potential contaminants }\end{array}$} & $\begin{array}{l}\text { Subsurface effects limited by relatively low contaminant } \\
\text { concentrations and volume and/or low mobility of } \\
\text { constituents }\end{array}$ & \multirow[t]{2}{*}{ Process knowledge } \\
\hline & $\begin{array}{l}\text { Potential UDP surface overflow complicates Heavy } \\
\text { Equipment Shop and Area } 3 \text { Photoshop site investigations }\end{array}$ & \\
\hline & $\begin{array}{l}\text { The radius of lateral contamination is not expected to extend } \\
\text { beyond } 10 \text { times the width of the UDP }\end{array}$ & $\begin{array}{l}\text { Proportions based on } \\
\text { experience with } \\
\text { CAU } 423\end{array}$ \\
\hline \multirow{2}{*}{$\begin{array}{l}\text { Vertical extent of } \\
\text { potential contaminants }\end{array}$} & $\begin{array}{l}\text { Vertical extent is unknown but is limited by low contaminant } \\
\text { concentrations and volumes, lack of driving force, relatively } \\
\text { low mobility of COPCs, and typically decreasing permeability } \\
\text { with increasing depth }\end{array}$ & Process knowledge \\
\hline & $\begin{array}{l}\text { Vertical contamination is not expected to exceed } 3 \text { times the } \\
\text { vertical dimension of the UDP below the UDP base }\end{array}$ & $\begin{array}{l}\text { Proportions based on } \\
\text { experience with } \\
\text { CAU } 423\end{array}$ \\
\hline \multirow{5}{*}{ System dynamics } & $\begin{array}{l}\text { COPCs primarily in liquid form were released to the UDPs; } \\
\text { effluent was mainly water with small amounts of } \\
\text { contaminants }\end{array}$ & $\begin{array}{l}\text { Quas, 1998a; } \\
\text { R. Smith, 1998; and } \\
\text { process knowledge }\end{array}$ \\
\hline & $\begin{array}{l}\text { Migration is primarily gravity controlled, but geologic control } \\
\text { at depth may influence or limit contaminant migration. }\end{array}$ & Process knowledge \\
\hline & $\begin{array}{l}\text { The UDPs are no longer in service; however, the Building } \\
09-52 \text { septic system is functional but abandoned }\end{array}$ & FADLs \\
\hline & $\begin{array}{l}\text { Arid climate limits infiltration; evapotranspiration rates are } \\
\text { high }\end{array}$ & $\begin{array}{l}\text { TTR Workplan } \\
\text { (DOE/NV, 1996a) }\end{array}$ \\
\hline & $\begin{array}{l}\text { The migration of contamination at the Building 03-60 UDP } \\
\text { (CAU 423), a similar site nearby, was limited both laterally } \\
\text { and vertically }\end{array}$ & DOE/NV, 1998 \\
\hline $\begin{array}{l}\text { Physical and practical } \\
\text { constraints }\end{array}$ & $\begin{array}{l}\text { Nearby utilities and buildings; adverse weather conditions; } \\
\text { restricted access; U.S. Air Force and/or Sandia range } \\
\text { activities }\end{array}$ & Process knowledge \\
\hline Future use & Similar to current use (light industrial) & DOE/NV, 1996b \\
\hline \multirow[b]{2}{*}{ Potential exposures } & $\begin{array}{l}\text { Oral ingestion, inhalation, or dermal contact (absorption) of } \\
\text { COPCs in the soil due to inadvertent exposure during } \\
\text { excavation }\end{array}$ & Process knowledge \\
\hline & $\begin{array}{l}\text { Very low exposure potential related to unlikely groundwater } \\
\text { contamination. Ground water is estimated to be at least } 130 \\
\text { feet below Area } 9 \text { and } 360 \text { feet below Area } 3 . \text { These depths } \\
\text { are between } 2.5 \text { and nearly } 10 \text { times the expected maximum } \\
\text { contamination depths. }\end{array}$ & $\begin{array}{l}\text { DOE/NV, 1996a; and } \\
\text { process knowledge }\end{array}$ \\
\hline
\end{tabular}

IT - IT Corporation

USACE - U.S. Army Corps of Engineers

ER - Environmental Restoration 


\section{A.3.0 Potential Contaminants}

Section 3.0 of the CAIP provides additional information on the COPCs for the UDP CAUs, including PALs and QA/QC requirements (Table A.3-1).

The COPCs for the UDPs form two basic groups:

- CAU 406 UDPs mainly received hydrocarbons associated with motorized equipment maintenance and operation and includes coolants, oils, fuels, and solvents. Only trace amounts of these products are expected. Tables A.3-1 and A.3-2 identify the COPCs for each CAS in CAU 406.

- CAU 429 UDPs mainly received RCRA Metals (especially silver) associated with photoprocessing waste. Table A.3-3 identifies the COPCs for CAU 429. 
Table A.3-1

CAU 406 Contaminants of Potential Concern (Heavy Duty Shop, CAS 03-51-002-0374)

\begin{tabular}{|c|c|c|c|c|c|c|c|}
\hline $\begin{array}{c}\text { Potential } \\
\text { Contaminants }\end{array}$ & Comments & $\begin{array}{c}\text { Field } \\
\text { Screening } \\
\text { Method }\end{array}$ & $\begin{array}{l}\text { Field } \\
\text { Screening } \\
\text { Level }\end{array}$ & $\begin{array}{c}\text { Conduct } \\
\text { Analytical? }\end{array}$ & $\begin{array}{l}\text { Preliminary } \\
\text { Action Level }\end{array}$ & $\begin{array}{l}\text { Analytical } \\
\text { Method }\end{array}$ & $\begin{array}{c}\text { Practical } \\
\text { Quantitation } \\
\text { Limit } \\
\text { (soil/water) }\end{array}$ \\
\hline $\begin{array}{l}\text { Volatile Organic } \\
\text { Compounds }\end{array}$ & $\begin{array}{l}\text { Waste } \\
\text { discharged } \\
\text { includes } \\
\text { coolants, oils, } \\
\text { fuels, and } \\
\text { solvents }\end{array}$ & Headspace & $\begin{array}{c}20 \text { ppm or } 2.5 X \\
\text { background } \\
\text { (use greater } \\
\text { value) }\end{array}$ & Yes & $\begin{array}{c}\text { PRGs }^{a} \\
\text { NAC } 445 A^{b}\end{array}$ & \multirow{6}{*}{$\begin{array}{c}\text { See } \\
\text { Appendix C }\end{array}$} & \multirow{6}{*}{$\begin{array}{c}\text { See } \\
\text { Appendix C }\end{array}$} \\
\hline $\begin{array}{l}\text { Semivolatile } \\
\text { Organic } \\
\text { Compounds }\end{array}$ & $\begin{array}{l}\text { Waste } \\
\text { discharged } \\
\text { includes } \\
\text { coolants, oils, } \\
\text { fuels, and } \\
\text { solvents }\end{array}$ & $\mathrm{N} / \mathrm{A}$ & $\mathrm{N} / \mathrm{A}$ & Yes & $\begin{array}{c}\text { PRGs }^{a} \\
\text { NAC } 445 A^{b}\end{array}$ & & \\
\hline $\begin{array}{l}\text { Total RCRA } \\
\text { Metals }\end{array}$ & $\begin{array}{l}\text { Metals may have } \\
\text { been discharged } \\
\text { at the Heavy } \\
\text { Duty Shop UDP }\end{array}$ & $\mathrm{N} / \mathrm{A}$ & $\mathrm{N} / \mathrm{A}$ & Yes & $\begin{array}{c}\text { PRGs }^{a} \\
\text { NAC } 445 A^{b}\end{array}$ & & \\
\hline $\begin{array}{l}\text { Total Petroleum } \\
\text { Hydrocarbons }\end{array}$ & $\begin{array}{l}\text { Waste } \\
\text { discharged } \\
\text { includes } \\
\text { coolants, oils, } \\
\text { fuels, and } \\
\text { solvents }\end{array}$ & Hanby $^{\mathrm{TM}}$ & >100 ppm & Yes & $\begin{array}{l}100 \mathrm{ppm}_{\mathrm{b}} \mathrm{b} \\
\text { NAC } 445 \mathrm{~A}\end{array}$ & & \\
\hline Total PCBs & $\begin{array}{l}\text { Highly unlikely, } \\
\text { but transformers } \\
\text { oils may have } \\
\text { entered the } \\
\text { Heavy Duty } \\
\text { Shop or Steam } \\
\text { Cleaning Pad } \\
\text { drains }\end{array}$ & $\mathrm{N} / \mathrm{A}$ & $\mathrm{N} / \mathrm{A}$ & Yes & $\begin{array}{c}\text { PRGs }^{a} \text { b } \\
\text { NAC } 445 A^{b}\end{array}$ & & \\
\hline Radionuclides & $\begin{array}{l}\text { Unlikely, but } \\
\text { some radioactive } \\
\text { material may } \\
\text { have been } \\
\text { washed from } \\
\text { vehicles into } \\
\text { UDP }\end{array}$ & $\begin{array}{l}\text { Electra TM } \\
\text { (alpha/beta } \\
\text { scintillator) }\end{array}$ & $\begin{array}{c}\text { Mean plus } 2 \\
\text { standard } \\
\text { deviations of } 20 \\
\text { background } \\
\text { sample } \\
\text { readings }\end{array}$ & $\begin{array}{l}\text { Only if field } \\
\text { screening } \\
\text { criteria } \\
\text { exceeded }\end{array}$ & $\begin{array}{l}\text { Isotope-specific } \\
\text { value based on } \\
\text { maximum } \\
\text { isotopic } \\
\text { background } \\
\text { data }\end{array}$ & & \\
\hline $\begin{array}{l}\text { Pesticides and } \\
\text { Herbicides }\end{array}$ & Not expected & $\mathrm{N} / \mathrm{A}$ & $\mathrm{N} / \mathrm{A}$ & No & & & \\
\hline
\end{tabular}

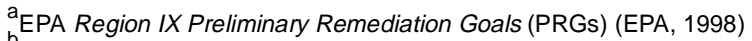

${ }^{\mathrm{b}}$ Nevada Administrative Code (NAC, 1998)

N/A - Not applicable 
Table A.3-2

CAU 406 Contaminants of Potential Concern

(Uninterrupted Power Supply Building, CAS 03-51-003-0358)

\begin{tabular}{|c|c|c|c|c|c|c|c|}
\hline $\begin{array}{c}\text { Potential } \\
\text { Contaminants }\end{array}$ & Comments & $\begin{array}{l}\text { Field Screening } \\
\text { Method }\end{array}$ & $\begin{array}{l}\text { Field Screening } \\
\text { Level }\end{array}$ & $\begin{array}{l}\text { Conduct } \\
\text { Analytical? }\end{array}$ & $\begin{array}{l}\text { Preliminary } \\
\text { Action Level }\end{array}$ & Analytical Method & $\begin{array}{c}\text { Practical } \\
\text { Quantitation } \\
\text { Limit } \\
\text { (soil/water) }\end{array}$ \\
\hline $\begin{array}{l}\text { Volatile Organic } \\
\text { Compounds }\end{array}$ & Unlikely & Headspace & $\begin{array}{c}20 \mathrm{ppm} \text { or } 2.5 \mathrm{X} \\
\text { background (use } \\
\text { greater value) }\end{array}$ & No & & & \\
\hline $\begin{array}{l}\text { Semivolatile Organic } \\
\text { Compounds }\end{array}$ & Unlikely & N/A & N/A & No & & & \\
\hline Total RCRA Metals & Unlikely & N/A & N/A & No & & & \\
\hline $\begin{array}{l}\text { Diesel/Waste Oil } \\
\text { Range Petroleum } \\
\text { Hydrocarbons }\end{array}$ & $\begin{array}{l}\text { Small amounts of } \\
\text { diesel, motor oil, } \\
\text { and antifreeze were } \\
\text { probably discharged } \\
\text { to the UDPs }\end{array}$ & Hanby ${ }^{\mathrm{TM}}$ & $>100$ ppm & Yes & $\begin{array}{l}100 \mathrm{ppm} \\
\text { NAC } 445 \mathrm{~A}^{\mathrm{a}}\end{array}$ & \multirow{3}{*}{ See Appendix C } & \multirow{3}{*}{ See Appendix C } \\
\hline Total PCBs & $\begin{array}{l}\text { Unlikely, but UPS } \\
\text { building may have } \\
\text { housed a } \\
\text { transformer }\end{array}$ & N/A & $\mathrm{N} / \mathrm{A}$ & Yes & $\begin{array}{l}\text { PRGs } \\
\text { NAC } 445 A^{a}\end{array}$ & & \\
\hline $\begin{array}{l}\text { Radionuclides by } \\
\text { Gamma Spectroscopy }\end{array}$ & Unlikely & $\begin{array}{l}\text { Electra }^{\mathrm{TM}} \text { (alpha/beta } \\
\text { scintillator) }\end{array}$ & $\begin{array}{l}\text { Mean plus } 2 \text { standard } \\
\text { deviations of } 20 \\
\text { background sample } \\
\text { readings }\end{array}$ & $\begin{array}{l}\text { Only if field } \\
\text { screening } \\
\text { criteria } \\
\text { exceeded }\end{array}$ & $\begin{array}{l}\text { Isotope-specific } \\
\text { value based on } \\
\text { maximum } \\
\text { isotopic } \\
\text { background data }\end{array}$ & & \\
\hline $\begin{array}{l}\text { Pesticides and } \\
\text { Herbicides }\end{array}$ & Not expected & $\mathrm{N} / \mathrm{A}$ & $\mathrm{N} / \mathrm{A}$ & No & & & \\
\hline
\end{tabular}

${ }^{a}$ Nevada Administrative Code (NAC, 1998)

EPA Region IX Preliminary Remediation Goals (PRGs) (EPA, 1998)

$\mathrm{N} / \mathrm{A}$ - Not applicable 
Table A.3-3

CAU 429 Contaminants of Potential Concern

\begin{tabular}{|c|c|c|c|c|c|c|c|}
\hline $\begin{array}{c}\text { Potential } \\
\text { Contaminants }\end{array}$ & Comments & $\begin{array}{l}\text { Field Screening } \\
\text { Method }\end{array}$ & $\begin{array}{c}\text { Field Screening } \\
\text { Level }\end{array}$ & $\begin{array}{l}\text { Conduct } \\
\text { Analytical? }\end{array}$ & $\begin{array}{c}\text { Preliminary } \\
\text { Action Level }\end{array}$ & Analytical Method & $\begin{array}{c}\text { Practical } \\
\text { Quantitation } \\
\text { Limit } \\
\text { (soil/water) }\end{array}$ \\
\hline TCLP Metals & \multirow{2}{*}{ Likely (esp. silver) } & \multirow{2}{*}{$\begin{array}{l}\text { X-ray fluorescence } \\
\text { (XRF) }\end{array}$} & \multirow{2}{*}{$<100$ ppm } & Limited & $\begin{array}{c}40 \text { CFR } 261.24 \\
\text { Table } 1^{\mathrm{a}}\end{array}$ & \multirow{4}{*}{ See Appendix C } & \multirow{4}{*}{ See Appendix C } \\
\hline Total RCRA Metals & & & & Yes & $\begin{array}{c}\text { PRGs }^{\mathrm{b}} \\
\text { NAC 445A }\end{array}$ & & \\
\hline $\begin{array}{l}\text { Volatile Organic } \\
\text { Compounds }\end{array}$ & $\begin{array}{l}\text { Possible, not } \\
\text { expected }\end{array}$ & Headspace & $\begin{array}{c}20 \text { ppm or } 2.5 X \\
\text { background (use } \\
\text { greater value) }\end{array}$ & Yes & $\begin{array}{l}\text { PRGs }{ }^{b} \\
\text { NAC 445A }\end{array}$ & & \\
\hline $\begin{array}{l}\text { Semivolatile Organic } \\
\text { Compounds }\end{array}$ & $\begin{array}{l}\text { Possible, not } \\
\text { expected }\end{array}$ & $\mathrm{N} / \mathrm{A}$ & $\mathrm{N} / \mathrm{A}$ & Yes & $\begin{array}{c}\text { PRGs }^{\mathrm{b}} \\
\text { NAC } 445 A^{\mathrm{c}}\end{array}$ & & \\
\hline $\begin{array}{l}\text { Total Petroleum } \\
\text { Hydrocarbons }\end{array}$ & Not expected & $\mathrm{N} / \mathrm{A}$ & N/A & No & & & \\
\hline Radionuclides & $\begin{array}{l}\text { Not expected } \\
\text { (elevated beta } \\
\text { results in Area } 9 \\
\text { septic tank sample) }\end{array}$ & $\begin{array}{l}\text { Electra }^{\mathrm{TM}} \\
\text { (alpha/beta } \\
\text { scintillator) }\end{array}$ & $\begin{array}{c}\text { Mean plus } 2 \\
\text { standard deviations } \\
\text { of } 20 \text { background } \\
\text { sample readings }\end{array}$ & $\begin{array}{l}\text { Only if field } \\
\text { screening } \\
\text { criteria } \\
\text { exceeded }\end{array}$ & $\begin{array}{l}\text { Isotope-specific } \\
\text { value based on } \\
\text { maximum } \\
\text { isotopic } \\
\text { background } \\
\text { data }\end{array}$ & See Appendix C & See Appendix C \\
\hline $\begin{array}{l}\text { Pesticides and } \\
\text { Herbicides }\end{array}$ & Not expected & $\mathrm{N} / \mathrm{A}$ & N/A & No & & & \\
\hline $\begin{array}{l}\text { Polychlorinated } \\
\text { Biphenyls }\end{array}$ & Not expected & $\mathrm{N} / \mathrm{A}$ & $\mathrm{N} / \mathrm{A}$ & No & & & \\
\hline
\end{tabular}

${ }^{\text {a } T i t l e ~} 40$ Code of Federal Regulations Part 261 (CFR, 1998)

${ }^{\mathrm{b}}$ EPA Region IX Preliminary Remediation Goals (PRGs) (EPA, 1998)

${ }^{\mathrm{C}}$ Nevada Administrative Code (NAC, 1998)

N/A - Not applicable 


\section{A.4.0 Decisions and Inputs}

\section{A.4.1 Decisions}

Decisions to be resolved by the investigation include:

- Determine if COPCs are present at the site.

- Determine if COPC concentrations exceed field screening levels.

- Determine if COPC concentrations exceed PALs.

- Determine the nature and extent of contamination with enough certainty to develop and evaluate a range of potential corrective actions, including closure in place and clean closure.

\section{A.4.2 Inputs and Strategy}

Inputs to the decisions include those elements of information used to support the decisions in addressing the identified problem. A list of information inputs, existing data, identified data gaps, and brief strategies are discussed in Table A.4-1. A more detailed discussion of investigation strategies is found in Section A.5.0. 
Table A.4-1

Decisions, Inputs, and General Strategies

(Page 1 of 2)

\begin{tabular}{|c|c|c|c|c|}
\hline Decision & Input & Existing Data & Data Gap & Strategy \\
\hline \multirow{3}{*}{$\begin{array}{l}\text { Are COPCs present } \\
\text { above PALs at site? }\end{array}$} & $\begin{array}{l}\text { Potential contaminant } \\
\text { identification }\end{array}$ & $\begin{array}{l}\text { Process knowledge of } \\
\text { potential discharges }\end{array}$ & Exact COPCs & $\begin{array}{l}\text { Collect laboratory samples; analyze } \\
\text { for COPCs }\end{array}$ \\
\hline & $\begin{array}{l}\text { Potential contaminant } \\
\text { concentration }\end{array}$ & $\begin{array}{c}\text { No sampling data available; } \\
\text { septic tank samples from } \\
\text { Building } 09-52 \text { septic tank are } \\
\text { available }\end{array}$ & $\begin{array}{l}\text { COPC concentrations; do } \\
\text { concentrations exceed } \\
\text { PALs? }\end{array}$ & $\begin{array}{l}\text { Collect field screening and } \\
\text { laboratory samples at biased } \\
\text { locations that represent worst case } \\
\text { for contamination; compare results } \\
\text { to field screening levels or to PALs }\end{array}$ \\
\hline & $\begin{array}{l}\text { Potential contaminant } \\
\text { distribution }\end{array}$ & $\begin{array}{l}\text { Locations of UDPs are known } \\
\text { or generally known with some } \\
\text { degree of certainty; vertical } \\
\text { and lateral extent limited by } \\
\text { small concentrations and } \\
\text { volumes, lack of driving force, } \\
\text { mobility of COPCs }\end{array}$ & $\begin{array}{l}\text { Exact vertical and lateral } \\
\text { extent }\end{array}$ & $\begin{array}{l}\text { Excavate to locate discharge lines } \\
\text { and UDPs as needed; drill through } \\
\text { center of UDPs to establish worst } \\
\text { case depth of COPCs; drill step-out } \\
\text { borings to determine lateral extent if } \\
\text { COPCs are detected; collect } \\
\text { laboratory samples to confirm extent }\end{array}$ \\
\hline \multirow{4}{*}{$\begin{array}{l}\text { Are potential } \\
\text { contaminants } \\
\text { migrating? }\end{array}$} & Meteorologic data & $\begin{array}{c}\text { Data on annual precipitation, } \\
\text { evapotranspiration, and } \\
\text { weather }\end{array}$ & None identified & $\begin{array}{c}\text { No specific meteorological data } \\
\text { collection anticipated; weather and } \\
\text { wind speed and direction noted on } \\
\text { daily field notes }\end{array}$ \\
\hline & Geologic/hydrologic data & $\begin{array}{l}\text { General geologic/hydrologic } \\
\text { characteristics of site; specific } \\
\text { geologic conditions of nearby } \\
\text { sites (i.e., CAU } 423,427,453 \text { ) }\end{array}$ & $\begin{array}{c}\text { Existence and } \\
\text { characteristics of differing } \\
\text { permeability zones }\end{array}$ & $\begin{array}{c}\text { Field log all core by qualified } \\
\text { geologist; collect and analyze } \\
\text { geotechnical samples }\end{array}$ \\
\hline & Biological degradation factors & $\begin{array}{l}\text { Potential hydrocarbons } \\
\text { release in CAU } 406\end{array}$ & $\begin{array}{c}\text { Presence of biomass; } \\
\text { biological parameters to } \\
\text { evaluate natural biological } \\
\text { process }\end{array}$ & $\begin{array}{l}\text { Collect microbial samples from } \\
\text { hydrocarbon sites for analysis of } \\
\text { biological parameters }\end{array}$ \\
\hline & Radioactive decay & $\begin{array}{l}\text { Radionuclides not expected in } \\
\text { Area 3; low probability of DU } \\
\text { at Heavy Duty Shop }\end{array}$ & $\begin{array}{l}\text { Presence and type of } \\
\text { radionuclides at CAU } 406\end{array}$ & $\begin{array}{l}\text { Establish background; field screen } \\
\text { for alpha/beta radiation using } \\
\text { ElectraTM instruments; collect } \\
\text { samples for gamma spec based on } \\
\text { field screening }\end{array}$ \\
\hline
\end{tabular}


Table A.4-1

Decisions, Inputs, and General Strategies

(Page 2 of 2)

\begin{tabular}{|c|c|c|c|c|}
\hline Decision & Input & Existing Data & Data Gap & Strategy \\
\hline \multirow{4}{*}{$\begin{array}{l}\text { Data sufficient to } \\
\text { support closure } \\
\text { options? }\end{array}$} & No further action & $\begin{array}{c}\text { Historical evidence that } \\
\text { COPCs released to the } \\
\text { environment; assume no } \\
\text { actions }\end{array}$ & $\begin{array}{l}\text { Presence, concentration, } \\
\text { and extent of COPCs }\end{array}$ & $\begin{array}{c}\text { Insufficient evidence to proceed } \\
\text { without investigation. Collect field } \\
\text { and laboratory samples; compare } \\
\text { results to PALs. If no COPCs above } \\
\text { PALs, prepare CADD/Closure } \\
\text { Report }\end{array}$ \\
\hline & Closure in place & $\begin{array}{l}\text { Potential for TPH and RCRA } \\
\text { constituents; assume } \\
\text { industrial PRGs per } \\
\text { NAC 445A (NAC, 1998); } \\
\text { assume use restrictions with } \\
\text { signs and fencing as needed }\end{array}$ & $\begin{array}{l}\text { Presence of regulated } \\
\text { COPCs; concentrations } \\
\text { above PALs }\end{array}$ & $\begin{array}{l}\text { Collect field and laboratory samples; } \\
\text { compare results to PALs. If no } \\
\text { COPCs above PALs, prepare } \\
\text { CADD/Closure Report; otherwise } \\
\text { prepare CADD }\end{array}$ \\
\hline & In situ bioremediation & $\begin{array}{c}\text { Hydrocarbons release in CAU } \\
\text { 406; assume } 100 \text { ppm PAL } \\
\text { per NAC } 445 \mathrm{~A}\end{array}$ & $\begin{array}{l}\text { Presence, concentration, } \\
\text { and extent of COPCs; } \\
\text { biodegradation parameters }\end{array}$ & $\begin{array}{l}\text { Collect field and laboratory samples; } \\
\text { compare results to PALs. If no } \\
\text { COPCs above PALs, prepare } \\
\text { CADD/Closure Report; otherwise } \\
\text { prepare CADD }\end{array}$ \\
\hline & $\begin{array}{l}\text { Clean closure by contaminant } \\
\text { removal }\end{array}$ & $\begin{array}{c}\text { Potential for TPH and RCRA } \\
\text { constituents; assume } \\
\text { industrial PRGs per } \\
\text { NAC } 445 A\end{array}$ & $\begin{array}{l}\text { Presence, concentration, } \\
\text { and extent of COPCs; } \\
\text { volume of contaminated } \\
\text { material above PALs }\end{array}$ & $\begin{array}{c}\text { Collect field and laboratory samples; } \\
\text { compare results to PALs. If no } \\
\text { COPCs above PALs, prepare } \\
\text { CADD/Closure Report; otherwise } \\
\text { prepare CADD }\end{array}$ \\
\hline
\end{tabular}




\section{A.5.0 Investigation Strategy}

Samples collected from both CAUs will be analyzed according to the appropriate COPC table as provided in Section A.3.0. At least one geotechnical sample will be collected from each site and analyzed for:

- Initial moisture content

- Dry bulk density

- Calculated porosity

- Moisture retention characteristics

- Particle size distribution

- Saturated and unsaturated hydraulic conductivity

At least one bioassessment sample will be collected from each site in CAU 406 if field screening detects COPCs.

Investigation of these CAUs may include use of a backhoe, direct-push method, and or hollow stem auger drill rig.

\section{A.5.1 Heavy Duty Maintenance Shop UDP}

Investigate the UDP using a three-phased approach:

- Excavate two to three trenches perpendicular to expected discharge line location; use video mole to inspect discharge line condition if possible:

- Between Area 3 West Fence and perimeter road

- At location of expected bend in discharge line near existing loading dock

- At additional locations if required due to breaks in discharge line

- Collect direct-push samples from 1 and $5 \mathrm{ft}$ bgs in wash

- Expected UDP location (south end of culvert)

- North end of culvert 
- 50 and $100 \mathrm{ft}$ south of UDP

- 100 and $200 \mathrm{ft}$ north of UDP

- Drill 1 borehole to $40 \mathrm{ft}$ bgs at UDP location (UDP assumed <10 ft deep)

- $5 \mathrm{ft}$ field screening and sampling interval

- Drill three stepout borings in triangular pattern at $25 \mathrm{ft}$ from the UDP if field screening levels are exceeded

- Additional stepout borings may be drilled as required

\section{A.5.2 Uninterrupted Power Supply Building UDPs}

Investigate the UDPs using a two phased approach:

- Excavate three trenches

- Two trenches parallel to discharge lines

- One trench perpendicular to and across two previous trenches at assumed UDP location

- Collect samples from excavations at assumed UDP locations

The second phase of this investigation will be initiated if COPCs are detected above field screening levels at the inferred UDP locations. One borehole will be drilled to $30 \mathrm{ft}$ bgs approximately $10 \mathrm{ft}$ west of Building 03-58 near the approximate location of the two UDPs or based on the results of the excavation activities in phase one. Field screening will be conducted in 5-ft intervals. If COPCs are detected above field screening levels in this borehole, three stepout boreholes will be drilled in a triangular pattern $15 \mathrm{ft}$ from this borehole. It will be difficult to distinguish between contamination related to surface fuel spills and waste liquid disposal related to the UDPs in both field screening and laboratory analysis. Additional stepout borings may be drilled as required.

\section{A.5.3 Area 3 Photoshop UDPs}

The location of these UDPs and the nature of contamination is well constrained. This site will be investigated in a three-phased approach:

- Collect direct-push samples from 1 and $3 \mathrm{ft}$ bgs in a 25-ft radius triangular pattern centered on primary UDP to detect potential surface or near surface contamination associated with overflow. 
- Drill borehole through initial UDP to $40 \mathrm{ft}$ bgs.

- 5-ft field screening and sampling interval

- Drill three 25-ft radius stepout borings in triangular pattern if field screening results exceed screening levels

- Drill borehole through secondary UDP to $40 \mathrm{ft}$ bgs.

- 5-ft field screening and sampling interval

- Drill three 25-ft radius stepout borings in triangular pattern if field screening results exceed screening levels

- Additional stepout borings may be drilled as required

\section{A.5.4 Area 9 Mobile Photo Labs UDPs}

The location of these UDPs and the nature of contamination is well constrained. Investigation of this site will require sampling the septic tank and drilling a borehole to $40 \mathrm{ft}$ bgs through each UDP. A 5-ft field screening and sampling interval will be used. If PALs are exceeded, 15-ft radius stepout borings will be drilled in a triangular pattern around the particular borehole(s). To prevent unauthorized discharge of materials to the UDP system, the line from Building 09-52 to the septic tank will be excavated and capped. Soil samples from the influent and effluent ends of the septic tank will be sampled either through excavation or drilling. Additional stepout borings may be drilled as required. 


\section{A.6.0 Decision Rules}

The following decision rules are applicable to all four UDP CASs and will be used to guide the investigation and subsequent data evaluation.

- If, in the course of the investigation, either of the following occur, then the investigation will be halted and rescoped as necessary:

- The conceptual model fails to such a degree that rescoping is required.

- Sufficient data are collected to support evaluation of corrective actions.

- For the subsurface investigation, if field screening indicates no COPCs above field-screening action levels, then a sample at the next prescribed subsurface location will be field-screened. If no COPCs are indicated, a confirmatory laboratory sample will be collected, and the subsurface investigation will be halted for that boring.

- For the subsurface investigation, if field screening indicates the presence of COPCs above field-screening levels, then the investigation will continue to determine extent of COPCs until two, consecutive samples with field screening results below field screening levels are obtained. Samples will be collected for laboratory analysis at the subsurface interval that represents the worst-case, field-screening result and as stated in the previous bulleted item.

- If laboratory results indicate the presence of COPCs above PALs, then a CADD will be prepared.

- If no COPCs are identified above PALs, then a CADD/Closure Report for CAUs with Contamination below Regulatory Limits will be prepared according to the outline agreed upon by NDEP and DOE/NV. This type of CADD incorporates the elements of the regular CADD and the corrective action plan and serves as the closure report for the site.

Table A.6-1 provides additional decision points and rules specific to each CAS. 
Table A.6-1

CAS-Specific Decision Points and Rules

(Page 1 of 2)

\begin{tabular}{|c|c|c|c|}
\hline $\begin{array}{l}\text { Investigation } \\
\text { Activity }\end{array}$ & Decision Point & $\begin{array}{l}\text { Decision } \\
\text { Result }\end{array}$ & Decision Rule \\
\hline \multicolumn{4}{|c|}{ Heavy Duty Shop UDP (CAS 03-51-002-0374) } \\
\hline \multirow{3}{*}{ Trenching } & \multirow{3}{*}{$\begin{array}{l}\text { Can discharge line } \\
\text { system be located? }\end{array}$} & Yes & Proceed with surface and subsurface investigation \\
\hline & & $\begin{array}{l}\text { Yes, but in a } \\
\text { different } \\
\text { location }\end{array}$ & Adjust investigation location \\
\hline & & No & $\begin{array}{l}\text { Line may have been removed; proceed with surface and subsurface investigation; } \\
\text { evaluate field data to determine if investigation is properly located; notify NDEP; adjust } \\
\text { investigation location as required }\end{array}$ \\
\hline \multirow[b]{2}{*}{$\begin{array}{l}\text { Surface and } \\
\text { Near-Surface } \\
\text { Investigation }\end{array}$} & \multirow{2}{*}{$\begin{array}{l}\text { Do field data from the } \\
\text { wash upgradient and } \\
\text { downgradient of the UDP } \\
\text { indicate contamination } \\
\text { above field screening } \\
\text { levels? }\end{array}$} & No & UDP represents point source; continue with planned subsurface investigation \\
\hline & & Yes & $\begin{array}{l}\text { UDP represents potential surface discharge; conceptual model fails; notify NDEP and } \\
\text { rescope investigation }\end{array}$ \\
\hline \multirow{2}{*}{$\begin{array}{l}\text { Subsurface } \\
\text { Investigation: Drill } \\
\text { through UDP; field } \\
\text { screen at 5-foot } \\
\text { intervals }\end{array}$} & \multirow[b]{2}{*}{$\begin{array}{l}\text { Are field data above field } \\
\text { screening levels? }\end{array}$} & No & Collect confirmatory samples from bottom of boring and end investigation \\
\hline & & Yes & $\begin{array}{l}\text { Continue drilling to obtain two consecutive samples below field screening levels; drill } \\
\text { step-out borings as needed to define lateral extent of contamination }\end{array}$ \\
\hline
\end{tabular}


Table A.6-1

CAS-Specific Decision Points and Rules

(Page 2 of 2)

\begin{tabular}{|c|c|c|c|}
\hline $\begin{array}{l}\text { Investigation } \\
\text { Activity }\end{array}$ & Decision Point & $\begin{array}{l}\text { Decision } \\
\text { Result }\end{array}$ & Decision Rule \\
\hline \multicolumn{4}{|c|}{ UPS UDPs (CAS 03-51-003-0358) } \\
\hline \multirow{3}{*}{$\begin{array}{l}\text { Pipeline Camera } \\
\text { Survey and } \\
\text { Trenching }\end{array}$} & \multirow{3}{*}{$\begin{array}{l}\text { Can discharge line and } \\
\text { UDP locations be } \\
\text { identified? }\end{array}$} & Yes & Proceed with surface and subsurface investigation \\
\hline & & $\begin{array}{l}\text { Yes, but in a } \\
\text { different } \\
\text { location }\end{array}$ & Adjust investigation location \\
\hline & & No & $\begin{array}{l}\text { Lines and UDPs may have been removed; proceed with surface and subsurface } \\
\text { investigation; evaluate field data to determine if investigation is properly located; notify } \\
\text { NDEP; adjust investigation location as required }\end{array}$ \\
\hline \multicolumn{4}{|c|}{ Photoprocessing UDPs (CAS 03-51-003-0358 \& 09-51-001-0952) } \\
\hline \multirow{3}{*}{$\begin{array}{l}\text { Field Screening of } \\
\text { Soil for Silver }\end{array}$} & \multirow{3}{*}{$\begin{array}{l}\text { Does XRF reliably } \\
\text { indicate silver? }\end{array}$} & Yes & Proceed with surface and subsurface investigation \\
\hline & & Unknown & $\begin{array}{l}\text { Collect additional samples for laboratory analysis; use alternate soil screening } \\
\text { technique(s) }\end{array}$ \\
\hline & & No & Notify NDEP, use alternate soil screening technique(s) \\
\hline
\end{tabular}




\section{A.7.0 Decision Error}

Biased sampling will be conducted on surface and subsurface samples at CAUs 406 and 429 as identified in Section A.4.0, A.5.0, and A.6.0. Biased sampling is appropriate because the UDPs are believed to be point sources and the locations are known or can be reasonably assumed. For the Heavy Duty Shop UDP, the assumed location will be verified prior to the surface and subsurface investigation. Section A.6.0 describes actions if the location cannot be identified. Because biased sampling is to be performed, confidence levels are built into the sampling program. The sampling strategy targets the worst-case contamination by drilling through, field screening, and sampling the individual UDPs. This will reduce the possibility of false positives and yield the highest confidence that the contamination problem has been adequately located and identified. Statistical sampling is not necessary for this type of investigation. In lieu of a quantitative determination of sampling error, the false positive error will be minimized by the following actions: two consecutive samples below field screening levels will be obtained from the soil borings to define the lower limit of the affected soils, and these field screening results will be confirmed clean through off-site laboratory analysis. 


\section{A.8.0 References}

AEC, see U.S. Atomic Energy Commission.

Atencio, I. 1994. Letter to S. Fain (ITLV), "Tonopah Test Range (TTR) Calendar Year 1993 (CY93) Chemical Inventory Report," 19 July. Albuquerque, NM: Sandia National Laboratories.

Blackburn, C. 1998. Record of Telecon with J. Markowsky (SAIC) regarding the Photoshop UDPs in Area 3, 16 and 30 March. Las Vegas, NV: IT Corporation.

Bull, G. 1998. Record of Telecon with J. Markowsky (SAIC) regarding the Mobile Photographic Laboratories UDPs in Area 9, 27 April. Las Vegas, NV: IT Corporation.

CFR, see Code of Federal Regulations.

Code of Federal Regulations. 1998. 40 CFR Part 261, "Identification and List of Hazardous Waste." Washington, DC: U.S. Government Printing Office.

DOE/NV, see U.S. Department of Energy, Nevada Operations Office.

EPA, see U.S. Environmental Protection Agency.

Fahrenhorst, M. 1998a. Record of Telecon with E. Dille (SAIC) regarding the Area 9 Mobile Photographic Labs UDPs, 11 March. Las Vegas, NV: IT Corporation.

Fahrenhorst, M. 1998b. Record of Telecon with J. Markowsky (SAIC) regarding the Area 9 Mobile Photographic Labs UDPs, 22 April. Las Vegas, NV: IT Corporation.

Forston, W. 1998. Record of Telecon with M. England (SAIC) regarding information on diesel spill cleanup at the UPS Building 03-58 at TTR, 20 April. Las Vegas, NV: IT Corporation.

IT Corporation. 1994a. Inspection of Building Structures at Sandia National Laboratories/Tonopah Test Range, August. Tonopah, NV: Sandia National Laboratories.

IT Corporation. 1994b. Sandia National Laboratories/New Mexico, Septic Tank Monitoring Report, Tonopah Test Range and Nevada Test Site. Tonopah, NV: Sandia National Laboratories.

IT Corporation. 1998. "Field Activity Daily Log," 14 May. Las Vegas, NV.

NAC, see Nevada Administrative Code.

Nevada Administrative Code. 1998. NAC 445A.2272, "Water Controls." Carson City, NV: Nevada Division of Environmental Protection. 
Phelan, J.M. 1988a. Memo entitled, "Environmental Restoration Program Status for Satellite Facilities,” 17 May. Albuquerque, NM: Sandia National Laboratories.

Phelan, J.M. 1988b. "Trip Report for Environmental Restoration Program/Tonopah Test Range," 1 March. Tonopah, NV: Sandia National Laboratories.

Quas, J. 1993. Record of Telecon with E. Mignardot (ITLV) regarding history of Area 3 at TTR, 15, 27, and 28 July. Las Vegas, NV: IT Corporation.

Quas, J. 1994. Record of Telecon with C. Swaton (HSI Geotrans) regarding information of the Area 3 UDPs, 7 June. Las Vegas, NV: IT Corporation.

Quas, J. 1998a. Record of Meeting with J. Markowsky (SAIC) regarding information on Area 3 at TTR, 13 May. Las Vegas, NV: IT Corporation.

Quas, J. 1998b. Record of Telecon with M. England (SAIC) regarding information pertaining to the UPS Building 03-58 UDPs at TTR, 3 April. Tonopah, NV.

Samuelson, T. 1998. Record of Telecon with J. Markowsky (SAIC) regarding operations at the Area 9 Building 0952, 22 April. Las Vegas, NV.

Sandia National Laboratories Plant Engineering. 1982a. Engineering Drawing Number 80131, “As Built, Toilet Facilities - Mechanical Building 952 Tonopah.” Tonopah, NV.

Sandia National Laboratories Plant Engineering. 1982b. Engineering Drawing Number 87614, Sheet 15, "As Built, Facilities Station 24 \& 9 - Plans and Details." Tonopah, NV.

Sandia National Laboratories Plant Engineering. 1985. Engineering Drawing Number 95679, Sheet M-1, “As Built, TTR Upgrade, Phase II, Heavy Vehicle Maintenance Facility.” Tonopah, NV.

Sandia National Laboratories Plant Engineering. 1989. Engineering Drawing Number G-3, "Sandia Master Utilities Plan." Tonopah, NV.

Sandia National Laboratories. 1987. Meeting notes by SNL personnel conducting a Preliminary Assessment of Area 3 at the TTR. Tonopah, NV.

Sandia National Laboratories. 1990-1993. Preliminary Hazard Assessments (PHA), Tonopah Test Range, Vol. 2. Albuquerque, NM: U.S. Department of Energy.

Sandia National Laboratories. 1992. Tonopah Test Range Facility Condition Inspections, Vol.1. Tonopah, NV.

Sandia National Laboratories. 1998. In-Situ Closure Plan, Area 3 UPS Building, Tonopah Test Range, Tonopah, Nevada. Albuquerque, NM. 
Schirber, A.L. 1984. Letter to G.J. Smith (SNL), "Environmental Audit of TTR on July 6, 1984," 10 October. Albuquerque, NM: Sandia National Laboratories.

Smith R. 1994a. Fax to C. Swaton (HSI Geotrans) including MSDSs for photo chemicals used in the Area 3 photo lab at TTR, 7 April. Las Vegas, NV: IT Corporation.

Smith, R. 1994b. Record of Telecon with C. Swaton (HSI Geotrans) regarding historical activities at the photo labs in Area 3 and Area 9 at TTR, 6 June. Las Vegas, NV: IT Corporation.

Smith, R. 1998. Record of Telecon with J. Markowsky (SAIC) regarding information pertaining to the Heavy Duty Shop UDP, 6 May. Las Vegas, NV: IT Corporation.

SNL, see Sandia National Laboratories.

U.S. Atomic Energy Commission. 1964. Engineering Drawing Number AL-TTD M/1, "Guard House \& Elect/Camera Repair Bldg. Utilities Plot Plan \& Profiles, Building Additions FY64.” Tonopah, NV.

U.S. Department of Energy, Nevada Operations Office. 1996a. Corrective Action Unit Work Plan, Tonopah Test Range, Nevada, Rev. 0, DOE/NV--443. Las Vegas, NV: Environmental Restoration Division.

U.S. Department of Energy, Nevada Operations Office. 1996b. Industrial Sites Quality Assurance Project Plan, DOE/NV--372. Las Vegas, NV.

U.S. Department of Energy, Nevada Operations Office. 1998. Corrective Action Decision Document for Corrective Action Unit 423: Building 03-60 Underground Discharge Point, Tonopah Test Range, Nevada, DOE/NV--508. Las Vegas, NV.

U.S. Environmental Protection Agency. 1998. Memo from S.J. Smucker to table mailing list regarding Region 9 Preliminary Remediation Goals (PRGs), 1 August. San Francisco, CA.

West, G. 1998. Record of Telecon with J. Markowsky (SAIC) regarding information pertaining to the Heavy Duty Shop UDP, 6 May. Las Vegas, NV: IT Corporation. 


\section{Appendix B}

\section{Project Organization}




\section{B.1.0 Project Organization}

The DOE/NV Project Manager is Janet Appenzeller-Wing, telephone (702) 295-0461.

The names of the project Health and Safety Officer and the Quality Assurance Officer can be found in the appropriate DOE/NV plan. However, personnel are subject to change, and it is suggested that the Project Manager be contacted for further information. The Task Manager will be identified in the FFACO Biweekly Activity Report prior to the start of field activities. 


\section{Appendix C}

\section{Laboratory Chemical, Toxicity Characteristic Leaching Procedure, and Radiochemistry Analytical Requirements for Industrial Sites}




\section{Appendix C \\ Laboratory Chemical, Toxicity Characteristic Leaching Procedure, and Radiochemistry Analytical Requirements for Industrial Sites}

(Page 1 of 5 )

\begin{tabular}{|c|c|c|c|c|c|c|}
\hline $\begin{array}{c}\text { Parameter or } \\
\text { Analyte }\end{array}$ & $\begin{array}{l}\text { Medium or } \\
\text { Matrix }\end{array}$ & $\begin{array}{l}\text { Analytical } \\
\text { Method }\end{array}$ & $\begin{array}{l}\text { Minimum } \\
\text { Reporting Limit }\end{array}$ & $\begin{array}{l}\text { Regulatory } \\
\text { Limit }\end{array}$ & $\begin{array}{c}\text { Relative } \\
\text { Percent } \\
\text { Difference } \\
\text { (RPD) } \\
\end{array}$ & $\begin{array}{l}\text { Percent } \\
\text { Recovery } \\
(\% R)^{b}\end{array}$ \\
\hline \multicolumn{7}{|c|}{ ORGANICS } \\
\hline \multirow{2}{*}{$\begin{array}{l}\text { Total Volatile } \\
\text { Organic Compounds } \\
\text { (VOCs) }\end{array}$} & Water & \multirow[b]{2}{*}{$8260 \mathrm{~B}^{\mathrm{C}}$} & \multirow{2}{*}{$\begin{array}{l}\text { Analyte-specific } \\
\text { estimated } \\
\text { quantitation } \\
\text { limits }^{d}\end{array}$} & \multirow[b]{2}{*}{$\begin{array}{c}\text { Not Applicable } \\
\text { (NA) }\end{array}$} & $14^{e}$ & $61-145^{e}$ \\
\hline & Soil & & & & $24^{e}$ & $59-172^{e}$ \\
\hline \multicolumn{7}{|l|}{$\begin{array}{c}\text { Toxicity } \\
\text { Characteristic } \\
\text { Leaching Procedure } \\
\text { (TCLP) VOCs }\end{array}$} \\
\hline Benzene & \multirow{10}{*}{ Aqueous } & \multirow{10}{*}{$1311 / 8260 \mathrm{~B}^{\mathrm{C}}$} & $0.050 \mathrm{mg} / \mathrm{L}^{\mathrm{d}}$ & $0.5 \mathrm{mg} / \mathrm{L}^{\mathrm{d}}$ & \multirow{10}{*}{$14^{\mathrm{e}}$} & \multirow{10}{*}{$61-145^{e}$} \\
\hline $\begin{array}{c}\text { Carbon } \\
\text { Tetrachloride }\end{array}$ & & & $0.050 \mathrm{mg} / \mathrm{L}^{\mathrm{d}}$ & $0.5 \mathrm{mg} / \mathrm{L}^{\mathrm{d}}$ & & \\
\hline Chlorobenzene & & & $0.050 \mathrm{mg} / \mathrm{L}^{\mathrm{d}}$ & $100 \mathrm{mg} / \mathrm{L}^{\mathrm{d}}$ & & \\
\hline Chloroform & & & $0.050 \mathrm{mg} / \mathrm{L}^{\mathrm{d}}$ & $6 \mathrm{mg} / \mathrm{L}^{\mathrm{d}}$ & & \\
\hline 1,2-Dichloroethane & & & $0.050 \mathrm{mg} / \mathrm{L}^{\mathrm{d}}$ & $0.5 \mathrm{mg} / \mathrm{L}^{\mathrm{d}}$ & & \\
\hline 1,1-Dichloroethene & & & $0.050 \mathrm{mg} / \mathrm{L}^{\mathrm{d}}$ & $0.7 \mathrm{mg} / \mathrm{L}^{\mathrm{d}}$ & & \\
\hline Methyl Ethyl Ketone & & & $0.050 \mathrm{mg} / \mathrm{L}^{\mathrm{d}}$ & $200 \mathrm{mg} / \mathrm{L}^{\mathrm{d}}$ & & \\
\hline Tetrachloroethene & & & $0.050 \mathrm{mg} / \mathrm{L}^{\mathrm{d}}$ & $0.7 \mathrm{mg} / \mathrm{L}^{\mathrm{d}}$ & & \\
\hline Trichloroethene & & & $0.050 \mathrm{mg} / \mathrm{L}^{\mathrm{d}}$ & $0.5 \mathrm{mg} / \mathrm{L}^{\mathrm{d}}$ & & \\
\hline Vinyl Chloride & & & $0.050 \mathrm{mg} / \mathrm{L}^{\mathrm{d}}$ & $0.2 \mathrm{mg} / \mathrm{L}^{\mathrm{d}}$ & & \\
\hline \multirow{2}{*}{$\begin{array}{l}\text { Total Semivolatile } \\
\text { Organic Compounds } \\
\text { (SVOCs) }\end{array}$} & Water & \multirow[b]{2}{*}{$8270 C^{c}$} & \multirow{2}{*}{$\begin{array}{l}\text { Analyte-specific } \\
\text { estimated } \\
\text { quantitation } \\
\text { limits }^{d}\end{array}$} & \multirow[b]{2}{*}{ NA } & $50^{e}$ & $9-127^{e}$ \\
\hline & Soil & & & & $50^{e}$ & $11-142^{e}$ \\
\hline \multicolumn{7}{|l|}{ TCLP SVOCs } \\
\hline o-Cresol & \multirow{6}{*}{ Aqueous } & \multirow{6}{*}{$1311 / 8270 C^{C}$} & $0.10 \mathrm{mg} / \mathrm{L}^{\mathrm{d}}$ & $200 \mathrm{mg} / \mathrm{L}^{\mathrm{d}}$ & \multirow{6}{*}{$50^{e}$} & \multirow{6}{*}{$9-127^{e}$} \\
\hline m-Cresol & & & $0.10 \mathrm{mg} / \mathrm{L}^{d}$ & $200 \mathrm{mg} / \mathrm{L}^{\mathrm{d}}$ & & \\
\hline p-Cresol & & & $0.10 \mathrm{mg} / \mathrm{L}^{d}$ & $200 \mathrm{mg} / \mathrm{L}^{\mathrm{d}}$ & & \\
\hline Cresol (total) & & & $0.30 \mathrm{mg} / \mathrm{L}^{\mathrm{d}}$ & $200 \mathrm{mg} / \mathrm{L}^{\mathrm{d}}$ & & \\
\hline $\begin{array}{l}\text { 1,4-Dichloro- } \\
\text { benzene }\end{array}$ & & & $0.10 \mathrm{mg} / \mathrm{L}^{\mathrm{d}}$ & $7.5 \mathrm{mg} / \mathrm{L}^{\mathrm{d}}$ & & \\
\hline 2,4-Dinitrotoluene & & & $0.10 \mathrm{mg} / \mathrm{L}^{d}$ & $0.13 \mathrm{mg} / \mathrm{L}^{d}$ & & \\
\hline
\end{tabular}




\section{Appendix C \\ Laboratory Chemical, Toxicity Characteristic Leaching Procedure, and Radiochemistry Analytical Requirements for Industrial Sites}

(Page 2 of 5 )

\begin{tabular}{|c|c|c|c|c|c|c|}
\hline $\begin{array}{c}\text { Parameter or } \\
\text { Analyte }\end{array}$ & $\begin{array}{l}\text { Medium or } \\
\text { Matrix }\end{array}$ & $\begin{array}{l}\text { Analytical } \\
\text { Method }\end{array}$ & $\begin{array}{l}\text { Minimum } \\
\text { Reporting Limit }\end{array}$ & $\begin{array}{l}\text { Regulatory } \\
\text { Limit }\end{array}$ & $\begin{array}{c}\text { Relative } \\
\text { Percent } \\
\text { Difference } \\
\text { (RPD) }^{\mathrm{a}}\end{array}$ & $\begin{array}{c}\text { Percent } \\
\text { Recovery } \\
(\% \mathrm{R})^{\mathbf{b}}\end{array}$ \\
\hline $\begin{array}{l}\text { Hexachloro- } \\
\text { benzene }\end{array}$ & \multirow{8}{*}{ Aqueous } & \multirow{8}{*}{$1311 / 8270 C^{c}$} & $0.10 \mathrm{mg} / \mathrm{L}^{\mathrm{d}}$ & $0.13 \mathrm{mg} / \mathrm{L}^{\mathrm{d}}$ & \multirow{8}{*}{$50^{e}$} & \multirow{8}{*}{$9-127^{e}$} \\
\hline $\begin{array}{l}\text { Hexachloro- } \\
\text { butadiene }\end{array}$ & & & $0.10 \mathrm{mg} / \mathrm{L}^{\mathrm{d}}$ & $0.5 \mathrm{mg} / \mathrm{L}^{\mathrm{d}}$ & & \\
\hline $\begin{array}{l}\text { Hexachloro- } \\
\text { ethane }\end{array}$ & & & $0.10 \mathrm{mg} / \mathrm{L}^{\mathrm{d}}$ & $3 \mathrm{mg} / \mathrm{L}^{\mathrm{d}}$ & & \\
\hline Nitrobenzene & & & $0.10 \mathrm{mg} / \mathrm{L}^{\mathrm{d}}$ & $2 \mathrm{mg} / \mathrm{L}^{\mathrm{d}}$ & & \\
\hline $\begin{array}{l}\text { Pentachloro- } \\
\text { phenol }\end{array}$ & & & $0.50 \mathrm{mg} / \mathrm{L}^{\mathrm{d}}$ & $100 \mathrm{mg} / \mathrm{L}^{\mathrm{d}}$ & & \\
\hline Pyridine & & & $0.10 \mathrm{mg} / \mathrm{L}^{\mathrm{d}}$ & $5 \mathrm{mg} / \mathrm{L}^{\mathrm{d}}$ & & \\
\hline $\begin{array}{c}\text { 2,4,5-Trichloro- } \\
\text { phenol }\end{array}$ & & & $0.10 \mathrm{mg} / \mathrm{L}^{\mathrm{d}}$ & $400 \mathrm{mg} / \mathrm{L}^{\mathrm{d}}$ & & \\
\hline $\begin{array}{l}\text { 2,4,6-Trichloro- } \\
\text { phenol }\end{array}$ & & & $0.10 \mathrm{mg} / \mathrm{L}^{\mathrm{d}}$ & $2 \mathrm{mg} / \mathrm{L}^{\mathrm{d}}$ & & \\
\hline \multirow{2}{*}{$\begin{array}{c}\text { Total } \\
\text { Pesticides }\end{array}$} & Water & \multirow{2}{*}{$8081 A^{C}$} & \multirow{2}{*}{$\begin{array}{l}\text { Analyte-specific } \\
\qquad(\mathrm{CRQL})^{\mathrm{e}}\end{array}$} & \multirow{2}{*}{ NA } & $27^{e}$ & $38-131^{e}$ \\
\hline & Soil & & & & $50^{e}$ & $23-139^{e}$ \\
\hline \multicolumn{7}{|l|}{$\begin{array}{c}\text { TCLP } \\
\text { Pesticides }\end{array}$} \\
\hline Chlordane & \multirow{7}{*}{ Aqueous } & \multirow{7}{*}{$1311 / 8081 A^{C}$} & $0.0005 \mathrm{mg} / \mathrm{L}^{\mathrm{e}}$ & $0.03 \mathrm{mg} / \mathrm{L}^{\mathrm{d}}$ & \multirow{7}{*}{$27^{e}$} & \multirow{7}{*}{$38-131^{e}$} \\
\hline Endrin & & & $0.001 \mathrm{mg} / \mathrm{L}^{\mathrm{e}}$ & $0.02 \mathrm{mg} / \mathrm{L}^{\mathrm{d}}$ & & \\
\hline Heptachlor & & & $0.0005 \mathrm{mg} / \mathrm{L}^{\mathrm{e}}$ & $0.008 \mathrm{mg} / \mathrm{L}^{\mathrm{d}}$ & & \\
\hline $\begin{array}{l}\text { Heptachlor } \\
\text { Epoxide }\end{array}$ & & & $0.0005 \mathrm{mg} / \mathrm{L}^{\mathrm{e}}$ & $0.008 \mathrm{mg} / \mathrm{L}^{\mathrm{d}}$ & & \\
\hline $\begin{array}{c}\text { Gamma-BHC } \\
\text { (Lindane) }\end{array}$ & & & $0.0005 \mathrm{mg} / \mathrm{L}^{\mathrm{e}}$ & $0.4 \mathrm{mg} / \mathrm{L}^{\mathrm{d}}$ & & \\
\hline Methoxychlor & & & $0.005 \mathrm{mg} / \mathrm{L}^{\mathrm{e}}$ & $10 \mathrm{mg} / \mathrm{L}^{\mathrm{d}}$ & & \\
\hline Toxaphene & & & $0.05 \mathrm{mg} / \mathrm{L}^{\mathrm{e}}$ & $0.5 \mathrm{mg} / \mathrm{L}^{\mathrm{d}}$ & & \\
\hline \multirow[b]{2}{*}{$\begin{array}{l}\text { Polychlorinated } \\
\text { Biphenyls (PCBs) }\end{array}$} & Water & \multirow[b]{2}{*}{$8082^{c}$} & \multirow{2}{*}{$\begin{array}{l}\text { Analyte-specific } \\
\text { contract required } \\
\text { quantitation limits } \\
\qquad(\mathrm{CRQL})^{\mathrm{e}}\end{array}$} & \multirow[b]{2}{*}{ NA } & \multirow[b]{2}{*}{ Lab-specific $^{f}$} & \multirow[b]{2}{*}{ Lab-specific $^{f}$} \\
\hline & Soil & & & & & \\
\hline \multirow{2}{*}{$\begin{array}{c}\text { Total } \\
\text { Herbicides }\end{array}$} & Water & \multirow{2}{*}{$8151 A^{C}$} & $1.3 \mu \mathrm{g} / \mathrm{L}^{\mathrm{c}}$ & \multirow{2}{*}{ NA } & \multirow{2}{*}{ Lab-specific $^{f}$} & \multirow{2}{*}{ Lab-specific $^{f}$} \\
\hline & Soil & & $66 \mu \mathrm{g} / \mathrm{kg}^{\mathrm{c}}$ & & & \\
\hline \multicolumn{7}{|l|}{$\begin{array}{c}\text { TCLP } \\
\text { Herbicides }\end{array}$} \\
\hline $2,4-D$ & \multirow{2}{*}{ Aqueous } & \multirow{2}{*}{$1311 / 8151 A^{c}$} & $0.002 \mathrm{mg} / \mathrm{L}^{\mathrm{d}}$ & $10 \mathrm{mg} / \mathrm{L}^{\mathrm{d}}$ & \multirow{2}{*}{ Lab-specific $^{f}$} & \multirow{2}{*}{ Lab-specific ${ }^{\dagger}$} \\
\hline $2,4,5-\mathrm{TP}$ & & & $0.00075 \mathrm{mg} / \mathrm{L}^{\mathrm{d}}$ & $1 \mathrm{mg} / \mathrm{L}^{\mathrm{d}}$ & & \\
\hline
\end{tabular}




\section{Appendix C \\ Laboratory Chemical, Toxicity Characteristic Leaching Procedure, and Radiochemistry Analytical Requirements for Industrial Sites}

(Page 3 of 5 )

\begin{tabular}{|c|c|c|c|c|c|c|}
\hline $\begin{array}{c}\text { Parameter or } \\
\text { Analyte }\end{array}$ & $\begin{array}{l}\text { Medium or } \\
\text { Matrix }\end{array}$ & $\begin{array}{l}\text { Analytical } \\
\text { Method }\end{array}$ & $\begin{array}{c}\text { Minimum } \\
\text { Reporting Limit }\end{array}$ & $\begin{array}{l}\text { Regulatory } \\
\text { Limit }\end{array}$ & $\begin{array}{l}\text { Relative } \\
\text { Percent } \\
\text { Difference } \\
\text { (RPD) }^{\mathbf{a}}\end{array}$ & $\begin{array}{c}\text { Percent } \\
\text { Recovery } \\
(\% \mathrm{R})^{\mathbf{b}}\end{array}$ \\
\hline \multirow{4}{*}{$\begin{array}{c}\text { Total Petroleum } \\
\text { Hydrocarbons (TPH) }\end{array}$} & $\begin{array}{c}\text { Water } \\
\text { Gasoline }\end{array}$ & \multirow{4}{*}{ 8015B modified ${ }^{c}$} & $0.1 \mathrm{mg} / \mathrm{L}^{\mathrm{g}}$ & \multirow{4}{*}{ NA } & \multirow{4}{*}{ Lab-specific $^{\dagger}$} & \multirow{4}{*}{ Lab-specific $^{\dagger}$} \\
\hline & Soil Gasoline & & $0.5 \mathrm{mg} / \mathrm{kg}^{\mathrm{g}}$ & & & \\
\hline & Water Diesel & & $0.5 \mathrm{mg} / \mathrm{L}^{\mathrm{g}}$ & & & \\
\hline & Soil Diesel & & $25 \mathrm{mg} / \mathrm{kg}^{\mathrm{g}}$ & & & \\
\hline \multirow{2}{*}{ Explosives } & Water & \multirow{2}{*}{$8330^{c}$} & $14 \mu \mathrm{g} / \mathrm{L}^{\mathrm{c}}$ & \multirow{2}{*}{ NA } & \multirow{2}{*}{ Lab-specific ${ }^{f}$} & \multirow{2}{*}{ Lab-specific ${ }^{f}$} \\
\hline & Soil & & $2.2 \mathrm{mg} / \mathrm{kg}^{\mathrm{c}}$ & & & \\
\hline \multirow{2}{*}{$\begin{array}{l}\text { Polychlorinated } \\
\text { Dioxins and Furans }\end{array}$} & Water & \multirow{2}{*}{$8280 A / 8290^{c}$} & $0.05 \mu \mathrm{g} / \mathrm{L}^{\mathrm{C}}$ & \multirow{2}{*}{ NA } & \multirow{2}{*}{ Lab-specific ${ }^{f}$} & \multirow{2}{*}{ Lab-specific ${ }^{f}$} \\
\hline & Soil & & $5 \mu \mathrm{g} / \mathrm{kg}^{\mathrm{c}}$ & & & \\
\hline \multicolumn{7}{|c|}{ INORGANICS } \\
\hline \multicolumn{7}{|l|}{$\begin{array}{c}\text { Total Resource } \\
\text { Conservation and } \\
\text { Recovery Act } \\
\text { (RCRA) Metals }\end{array}$} \\
\hline \multirow{2}{*}{ Arsenic } & Water & $6010 \mathrm{~B} / 7470 \mathrm{~A}^{\mathrm{C}}$ & $10 \mu \mathrm{g} / \mathrm{L}^{\mathrm{g}, \mathrm{h}}$ & \multirow{16}{*}{ NA } & \multirow{16}{*}{$20^{h}$} & \multirow{16}{*}{$75-125^{\mathrm{h}}$} \\
\hline & Soil & $6010 \mathrm{~B} / 7471 \mathrm{~A}^{\mathrm{C}}$ & $1 \mathrm{mg} / \mathrm{kg}^{\mathrm{g}, \mathrm{h}}$ & & & \\
\hline \multirow{2}{*}{ Barium } & Water & $6010 \mathrm{~B} / 7470 \mathrm{~A}^{\mathrm{C}}$ & $200 \mu \mathrm{g} / \mathrm{L}^{\mathrm{g}, \mathrm{h}}$ & & & \\
\hline & Soil & $6010 \mathrm{~B} / 7471 \mathrm{~A}^{\mathrm{C}}$ & $20 \mathrm{mg} / \mathrm{kg}^{\mathrm{g}, \mathrm{h}}$ & & & \\
\hline \multirow{2}{*}{ Cadmium } & Water & $6010 \mathrm{~B} / 7470 \mathrm{~A}^{\mathrm{C}}$ & $5 \mu \mathrm{g} / \mathrm{L}^{\mathrm{g}, \mathrm{h}}$ & & & \\
\hline & Soil & $6010 \mathrm{~B} / 7471 \mathrm{~A}^{\mathrm{C}}$ & $0.5 \mathrm{mg} / \mathrm{kg}^{\mathrm{g}, \mathrm{h}}$ & & & \\
\hline \multirow{2}{*}{ Chromium } & Water & $6010 \mathrm{~B} / 7470 \mathrm{~A}^{\mathrm{c}}$ & $10 \mu \mathrm{g} / \mathrm{L}^{\mathrm{g}, \mathrm{h}}$ & & & \\
\hline & Soil & $6010 \mathrm{~B} / 7471 \mathrm{~A}^{\mathrm{C}}$ & $1 \mathrm{mg} / \mathrm{kg}^{\mathrm{g}, \mathrm{h}}$ & & & \\
\hline \multirow{2}{*}{ Lead } & Water & $6010 \mathrm{~B} / 7470 \mathrm{~A}^{\mathrm{C}}$ & $3 \mu \mathrm{g} / \mathrm{L}^{\mathrm{g}, \mathrm{h}}$ & & & \\
\hline & Soil & $6010 \mathrm{~B} / 7471 \mathrm{~A}^{\mathrm{C}}$ & $0.3 \mathrm{mg} / \mathrm{kg}^{\mathrm{g}, \mathrm{h}}$ & & & \\
\hline \multirow{2}{*}{ Mercury } & Water & $6010 \mathrm{~B} / 7470 \mathrm{~A}^{\mathrm{C}}$ & $0.2 \mu \mathrm{g} / \mathrm{L}^{\mathrm{g}, \mathrm{h}}$ & & & \\
\hline & Soil & $6010 \mathrm{~B} / 7471 \mathrm{~A}^{\mathrm{C}}$ & $0.1 \mathrm{mg} / \mathrm{kg}^{\mathrm{g}, \mathrm{h}}$ & & & \\
\hline \multirow{2}{*}{ Selenium } & Water & $6010 \mathrm{~B} / 7470 \mathrm{~A}^{\mathrm{C}}$ & $5 \mu \mathrm{g} / \mathrm{L}^{\mathrm{g}, \mathrm{h}}$ & & & \\
\hline & Soil & $6010 \mathrm{~B} / 7471 \mathrm{~A}^{\mathrm{C}}$ & $0.5 \mathrm{mg} / \mathrm{kg}^{\mathrm{g}, \mathrm{h}}$ & & & \\
\hline \multirow{2}{*}{ Silver } & Water & $6010 \mathrm{~B} / 7470 \mathrm{~A}^{\mathrm{C}}$ & $10 \mu \mathrm{g} / \mathrm{L}^{\mathrm{g}, \mathrm{h}}$ & & & \\
\hline & Soil & $6010 \mathrm{~B} / 7471 \mathrm{~A}^{\mathrm{C}}$ & $1 \mathrm{mg} / \mathrm{kg}^{\mathrm{g}, \mathrm{h}}$ & & & \\
\hline
\end{tabular}




\section{Appendix C \\ Laboratory Chemical, Toxicity Characteristic Leaching Procedure, and Radiochemistry Analytical Requirements for Industrial Sites}

(Page 4 of 5 )

\begin{tabular}{|c|c|c|c|c|c|c|}
\hline $\begin{array}{c}\text { Parameter or } \\
\text { Analyte }\end{array}$ & $\begin{array}{l}\text { Medium or } \\
\text { Matrix }\end{array}$ & $\begin{array}{l}\text { Analytical } \\
\text { Method }\end{array}$ & $\begin{array}{c}\text { Minimum } \\
\text { Reporting Limit }\end{array}$ & $\begin{array}{l}\text { Regulatory } \\
\text { Limit }\end{array}$ & $\begin{array}{c}\text { Relative } \\
\text { Percent } \\
\text { Difference } \\
\text { (RPD) }^{\mathbf{a}}\end{array}$ & $\begin{array}{c}\text { Percent } \\
\text { Recovery } \\
(\% \mathrm{R})^{\mathbf{b}}\end{array}$ \\
\hline \multicolumn{7}{|l|}{$\begin{array}{l}\text { TCLP RCRA } \\
\text { Metals }\end{array}$} \\
\hline Arsenic & \multirow{8}{*}{ Aqueous } & \multirow{8}{*}{$\begin{array}{l}1311 / 6010 B^{C} \\
1311 / 7470 A^{C}\end{array}$} & $0.10 \mathrm{mg} / \mathrm{L}^{\mathrm{g}, \mathrm{h}}$ & $5 \mathrm{mg} / \mathrm{L}^{\mathrm{d}}$ & \multirow{8}{*}{$20^{h}$} & \multirow{8}{*}{$75-125^{h}$} \\
\hline Barium & & & $2 \mathrm{mg} / \mathrm{L}^{\mathrm{g}, \mathrm{h}}$ & $100 \mathrm{mg} / \mathrm{L}^{\mathrm{d}}$ & & \\
\hline Cadmium & & & $0.05 \mathrm{mg} / \mathrm{L}^{\mathrm{g}, \mathrm{h}}$ & $1 \mathrm{mg} / \mathrm{L}^{\mathrm{d}}$ & & \\
\hline Chromium & & & $0.10 \mathrm{mg} / \mathrm{L}^{\mathrm{g}, \mathrm{h}}$ & $5 \mathrm{mg} / \mathrm{L}^{\mathrm{d}}$ & & \\
\hline Lead & & & $0.03 \mathrm{mg} / \mathrm{L}^{\mathrm{g}, \mathrm{h}}$ & $5 \mathrm{mg} / \mathrm{L}^{\mathrm{d}}$ & & \\
\hline Mercury & & & $0.002 \mathrm{mg} / \mathrm{L}^{\mathrm{g}, \mathrm{h}}$ & $0.2 \mathrm{mg} / \mathrm{L}^{\mathrm{d}}$ & & \\
\hline Selenium & & & $0.05 \mathrm{mg} / \mathrm{L}^{\mathrm{g}, \mathrm{h}}$ & $1 \mathrm{mg} / \mathrm{L}^{\mathrm{d}}$ & & \\
\hline Silver & & & $0.10 \mathrm{mg} / \mathrm{L}^{\mathrm{g}, \mathrm{h}}$ & $5 \mathrm{mg} / \mathrm{L}^{\mathrm{d}}$ & & \\
\hline \multirow{2}{*}{ Cyanide } & Water & \multirow{2}{*}{$9010 \mathrm{~B}^{\mathrm{C}}$} & $0.01 \mathrm{mg} / \mathrm{L}^{\mathrm{h}}$ & \multirow{2}{*}{ NA } & \multirow{2}{*}{$20^{h}$} & \multirow{2}{*}{$75-125^{h}$} \\
\hline & Soil & & $1.0 \mathrm{mg} / \mathrm{kg}^{\mathrm{h}}$ & & & \\
\hline \multirow[b]{2}{*}{ Sulfide } & Water & \multirow[b]{2}{*}{$9030 \mathrm{~B} / 9034^{\mathrm{C}}$} & $0.4 \mathrm{mg} / \mathrm{L}^{\mathrm{c}}$ & \multirow[b]{2}{*}{ NA } & \multirow[b]{2}{*}{ Lab-specific ${ }^{f}$} & \multirow[b]{2}{*}{ Lab-specific $^{f}$} \\
\hline & $\begin{array}{c}\text { Soil or } \\
\text { Sediment }\end{array}$ & & $10 \mathrm{mg} / \mathrm{kg}^{\mathrm{g}}$ & & & \\
\hline \multirow{2}{*}{$\mathrm{pH} /$ Corrosivity } & Water & $9040 \mathrm{~B}^{\mathrm{C}}$ & \multirow{2}{*}{ NA } & $\mathrm{pH}>2^{\mathrm{i}}$ & \multirow{2}{*}{ Lab-specific $^{\dagger}$} & \multirow{2}{*}{ Lab-specific ${ }^{\dagger}$} \\
\hline & Soil & $9045 C^{c}$ & & $\mathrm{pH}<12.5^{\mathrm{i}}$ & & \\
\hline \multirow[b]{2}{*}{ Ignitability } & Water & $1010^{C}$ & \multirow[b]{2}{*}{ NA } & $\begin{array}{l}\text { Flash Point } \\
<140^{\circ} \mathrm{F}^{\mathrm{d}}\end{array}$ & & \multirow[b]{2}{*}{ NA } \\
\hline & Soil & $1030^{c}$ & & $\begin{array}{c}\text { Burn Rate } \\
>2.2 \mathrm{~mm} / \mathrm{sec} \\
\text { nonmetals; } \\
>0.17 \mathrm{~mm} / \mathrm{sec} \\
\quad \text { metals }\end{array}$ & NA & \\
\hline \multicolumn{7}{|c|}{ RADIOCHEMISTRY } \\
\hline \multirow{2}{*}{$\begin{array}{l}\text { Gamma-emitting } \\
\text { Radionuclides }\end{array}$} & Water & EPA $901.1^{\mathrm{k}}$ & \multirow{2}{*}{ Isotope-specific ${ }^{m}$} & \multirow{2}{*}{ NA } & 20 & \multirow{8}{*}{$\begin{array}{c}\text { Tracer Yield } \\
30-105 \\
\text { Laboratory } \\
\text { Control } \\
\text { Sample Yield } \\
80-120\end{array}$} \\
\hline & Soil & HASL $300^{\prime}$ & & & 35 & \\
\hline & Water & & $2 \mathrm{pCi} / \mathrm{L}$ & & 20 & \\
\hline $\begin{array}{l}\text { Isotopic } \\
\text { Plutonium }\end{array}$ & Soil & NAS-NS-3058 & $\begin{array}{c}0.1 \mathrm{pCi} / \mathrm{g} \\
\mathrm{Pu}-238^{\mathrm{p}} \\
0.4 \mathrm{pCi} / \mathrm{g} \\
\mathrm{Pu}-239 / 240^{\mathrm{p}}\end{array}$ & NA & 35 & \\
\hline \multirow{2}{*}{$\begin{array}{l}\text { Isotopic } \\
\text { Uranium }^{\mathrm{j}}\end{array}$} & Water & \multirow{2}{*}{ NAS-NS-3050q,r } & $2 \mathrm{pCi} / \mathrm{L}$ & \multirow{2}{*}{ NA } & 20 & \\
\hline & Soil & & $1 \mathrm{pCi} / \mathrm{g}$ & & 35 & \\
\hline \multirow{2}{*}{ Strontium - $90^{j}$} & Water & SM 7500-Srs & $8 \mathrm{pCi} / \mathrm{L}^{\mathrm{t}}$ & \multirow{2}{*}{ NA } & 20 & \\
\hline & Soil & Martin $79^{u}$ & $1 \mathrm{pCi} / \mathrm{g}^{\vee}$ & & 35 & \\
\hline
\end{tabular}




\title{
Appendix C \\ Laboratory Chemical, Toxicity Characteristic Leaching Procedure, and Radiochemistry Analytical Requirements for Industrial Sites
}

\author{
(Page 5 of 5 )
}

\author{
${ }^{a}$ RPD is used to Calculate Precision \\ Precision is estimated from the relative percent difference of the concentrations measured for the matrix spike and matrix spike \\ duplicate analyses of unspiked field samples, or field duplicates of unspiked samples. It is calculated by: \\ $\mathrm{RPD}=100 \times\left\{\left(\left|\mathrm{C}_{1}-\mathrm{C}_{2}\right|\right) /\left[\left(\mathrm{C}_{1}+\mathrm{C}_{2}\right) / 2\right]\right\}$, where $\mathrm{C}_{1}=$ Concentration of the analyte in the first sample aliquot, $\mathrm{C}_{2}=$ Concentration of \\ the analyte in the second sample aliquot. \\ $b_{\%} \mathrm{R}$ is used to Calculate Accuracy \\ Accuracy is assessed from the recovery of analytes spiked into a blank or sample matrix of interest, or from the recovery of \\ surrogate compounds spiked into each sample. The recovery of each spiked analyte is calculated by: \%R $=100 \times\left(C_{s}-C_{u} / C_{n}\right)$, \\ where $C_{s}=$ Concentration of the analyte in the spiked sample, $C_{u}=$ Concentration of the analyte in the unspiked sample, \\ $\mathrm{C}_{\mathrm{n}}=$ Concentration increase that should result from spiking the sample \\ CU.S. Environmental Protection Agency (EPA) Test Methods for Evaluating Solid Waste, 3rd Edition, Parts 1-4, SW-846 \\ (EPA, 1996) \\ ${ }^{d}$ Estimated Quantitation Limit as given in SW-846 (EPA, 1996) \\ eEPA Contract Laboratory Program Statement of Work for Organic Analysis (EPA, 1988b; 1990; 1991; and 1994b) \\ ${ }^{f}$ In-House Generated RPD and \%R Performance Criteria \\ It is necessary for laboratories to develop in-house performance criteria and compare them to those in the methods. The \\ laboratory begins by analyzing 15-20 samples of each matrix and calculating the mean \%R for each analyte. The standard \\ deviation (SD) of each \%R is then calculated, and the warning and control limits for each analyte are established at \pm 2 SD and \\ \pm 3 SD from the mean, respectively. If the warning limit is exceeded during the analysis of any sample delivery group (SDG), \\ the laboratory institutes corrective action to bring the analytical system back into control. If the control limit is exceeded, the \\ sample results for that SDG are considered unacceptable. These limits are reviewed after every 20-30 field samples of the \\ same matrix and are updated at least semiannually. The laboratory tracks trends in both performance and control limits by the \\ use of control charts. The laboratory's compliance with these requirements is confirmed as part of an annual laboratory audit. \\ Similar procedures are followed in order to generate acceptance criteria for precision measurements. \\ IIndustrial Sites Quality Assurance Project Plan (DOE/NV, 1996) \\ hEPA Contract Laboratory Program Statement of Work for Inorganic Analysis (EPA, 1988a; 1993; and 1994a) \\ iRCRA Regulations and Keyword Index, 1998 Edition \\ Isotopic minimum detectable concentrations are defined during the DQO process and specified in the CAIP as applicable \\ ${ }^{\mathrm{k}}$ Prescribed Procedures for Measurements of Radioactivity in Drinking Water (EPA, 1980) or equivalent method \\ 'Environmental Measurements Laboratory Procedures Manual (DOE, 1992) or equivalent method

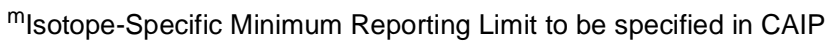 \\ ${ }^{\mathrm{n}}$ The Radiochemistry of Plutonium (Coleman, 1965) or equivalent method \\ ${ }^{\circ}$ Separation and Preconcentration of Actinides from Acidic Media by Extraction Chromatography (Horwitz, 1993) or equivalent \\ method \\ PThe Nevada Test Site Performance Objective Criteria requirement for certifying that hazardous waste has no added \\ radioactivity requires that the total plutonium (the sum of the $\mathrm{Pu}-238,239,240$ concentrations) not exceed $0.5 \mathrm{pCi} / \mathrm{g}$ (BN, 1995) \\ १The Radiochemistry of Uranium (Grindler, 1962) or equivalent method \\ 'Separation and Preconcentration of Uranium from Acidic Media by Extraction Chromatography (Horwitz, 1992) or equivalent \\ method \\ sStandard Methods for the Examination of Water and Waste Water (APHA, 1992) or equivalent method \\ t 40 CFR 141.16, Table A, "Average Annual Concentrations Assumed to Produce a Total Body or Organ Dose of $4.0 \mathrm{mrem} / \mathrm{yr}$ " \\ (CFR, 1976) \\ u Determination of Strontium-89 and -90 in soil with Total Sample Decomposition (Analytical Chemistry, 1979) or equivalent \\ method \\ ${ }^{\vee}$ The $1.0 \mathrm{pCi} / \mathrm{g}$ concentration is approximately twice the concentration of fallout $\mathrm{Sr}-90$ in background surface soils reported in the \\ "Environmental Monitoring Report for the Proposed Ward Valley California Low-Level Radioactive Waste Facility" \\ (Atlan-Tech, 1992)
}

Definitions:

$\mu \mathrm{g} / \mathrm{kg}=$ Microgram(s) per kilogram $\mathrm{mg} / \mathrm{kg}=$ Milligram(s) per kilogram

$\mathrm{pCi} / \mathrm{L}=$ Picocurie(s) per liter $\mathrm{mg} / \mathrm{L}=$ Milligram(s) per liter $\mathrm{pCi} / \mathrm{g}=$ Picocurie(s) per gram $\mu \mathrm{g} / \mathrm{L}=$ Microgram(s) per liter 


\section{C.1.0 References}

APHA, see American Public Health Association.

American Public Health Association. 1992. Standard Methods for the Examination of Water and Waste Water, 18th Edition. Washington, DC.

Analytical Chemistry. 1979. Determination of Strontium-89 and -90 in Soil with Total Sample Decomposition, Martin 79. October.

Atlan-Tech. 1992. Environmental Monitoring Report for the Proposed Ward Valley California Low-Level Radioactive Waste Facility. Roswell, GA.

Bechtel Nevada. 1995. Nevada Test Site Performance Objective for Certification of Nonradioactive Hazardous Waste, Rev. 0. Las Vegas, NV.

Code of Federal Regulations. 1976. 40 CFR 141.16, Table A, "Average Annual Concentrations Assumed to Produce a Total Body or Organ Dose of 4 mrem/yr." Washington, DC: U.S. Government Printing Office.

Coleman, G.H. 1965. The Radiochemistry of Plutonium, NAS-NS-3058. Washington, DC: National Academy of Sciences.

Grindler, J.E. 1962. The Radiochemistry of Uranium, NAS-NS-3050. Washington, DC: National Academy of Science.

Horwitz. 1992. "Separation and Preconcentration of Uranium from Acidic Media by Extraction Chromatography." In Analyticda Chimica Acta.

Horwitz. 1993. "Separation and Preconcentration of Actinides from Acidic Media by Extraction Chromatography." In Analyticda Chimica Acta.

RCRA Regulations and Keyword Index. 1998. ISSN 1074-1364. New York, NY: Elsevier Science Inc.

U.S. Department of Energy. 1992. Environmental Measurements Laboratory Procedures Manual, HASL-300, 27th Edition, Vol. 1. New York, NY.

U.S. Department of Energy, Nevada Operations Office. 1996. Industrial Sites Quality Assurance Project Plan, Nevada Test Site, Nevada, DOE/NV--372. Las Vegas, NV.

U.S. Environmental Protection Agency. 1980. Prescribed Procedures for Measurements of Radioactivity in Drinking Water, EPA-600/4-79-020. Washington, DC. 
U.S. Environmental Protection Agency. 1988a. Contract Laboratory Program Statement of Work for Inorganic Analysis, ILMO 3.0. Washington, DC.

U.S. Environmental Protection Agency. 1988b. Contract Laboratory Program Statement of Work for Organic Analysis, 2/88. Washington, DC.

U.S. Environmental Protection Agency. 1990. Contract Laboratory Program Statement of Work for Organic Analysis, 3/90. Washington, DC.

U.S. Environmental Protection Agency. 1991. Contract Laboratory Program Statement of Work for Organic Analysis, OLMO 1.8. Washington, DC.

U.S. Environmental Protection Agency. 1993. Contract Laboratory Program Statement of Work for Inorganic Analysis, ILMO 3.0. Washington, DC.

U.S. Environmental Protection Agency. 1994a. Contract Laboratory Program Statement of Work for Inorganic Analysis, ILMO 4.0. Washington, DC.

U.S. Environmental Protection Agency. 1994b. Contract Laboratory Program Statement of Work for Organic Analysis, OLMO 3.1. Washington, DC.

U.S. Environmental Protection Agency. 1996. Test Methods for Evaluating Solid Waste, Physical/Chemical Methods, SW-846, $3^{\text {rd }}$ Edition (which includes updates to 1986, 1992, and 1994 revisions), CD-ROM. Washington, DC. 
Date: 05/21/99

Page D-1 of D-3

\section{Appendix D}

\section{NDEP Comments}




\section{NEVADA ENVIRONMENTAL RESTORATION PROJECT}

\section{DOCUMENT REVIEW SHEET}

\begin{tabular}{|c|c|c|c|c|c|}
\hline \multicolumn{4}{|c|}{$\begin{array}{l}\text { 1. Document Title/Number: Corrective Action Investigation Plan for Corrective Action Unit 406: Area } 3 \\
\text { Building 03-74 \& Building 03-58 Underground Discharge Points and Corrective Action Unit 429: Area } 3 \\
\text { Building 03-55 \& Area } 9 \text { Building 09-52 Underground Discharge Points, TTR, NV Draft }\end{array}$} & \multicolumn{2}{|c|}{ 2. Document Date: March 1999} \\
\hline \multicolumn{4}{|c|}{ 3. Revision Number: 0} & \multicolumn{2}{|c|}{ 4. Originator/Organization: IT Corporation } \\
\hline \multicolumn{4}{|c|}{ 5. Responsible DOE/NV ERP Project Mgr.: Janet Appenzeller-Wing } & \multicolumn{2}{|c|}{ 6. Date Comments Due: } \\
\hline \multicolumn{6}{|l|}{ 7. Review Criteria: } \\
\hline \multicolumn{4}{|c|}{ 8. Reviewer/Organization/Phone No.: Gregory Raab, NDEP. 486-2867 } & \multicolumn{2}{|c|}{ 9. Reviewer's Signature: } \\
\hline $\begin{array}{l}\text { 10. Comment } \\
\text { Number/ } \\
\text { Location }\end{array}$ & 11. Type ${ }^{*}$ & 12. Comment & \multicolumn{2}{|c|}{ 13. Comment Response } & $\begin{array}{l}14 . \\
\text { Accep }\end{array}$ \\
\hline $\begin{array}{l}\text { 1) Page ES-2 of } \\
\text { ES- } 3,1^{\text {st }} \\
\text { Paragraph After } \\
\text { Bullet List }\end{array}$ & & $\begin{array}{l}\text { A more detailed conceptual site model is presented } \\
\text {...The conceptual site model serves... }\end{array}$ & \multicolumn{2}{|c|}{ The text has been added. } & Yes \\
\hline $\begin{array}{l}\text { 2) Section } 3.1 \\
\text { Page } 19 \text { of } 52 \text {, } \\
1^{\text {st }} \text { Paragraph After } \\
2^{\text {nd }} \text { Sentence }\end{array}$ & & $\begin{array}{l}\text { The cross-section in Figure 2-1 depicts a graphical representation of } \\
\text { the estimated COPCs }\end{array}$ & \multicolumn{2}{|c|}{ The text has been added. } & Yes \\
\hline $\begin{array}{l}\text { 3) Section 3.1, } \\
\text { Page } 19 \text { of 52, } \\
2^{\text {nd }} \text { Paragraph, } \\
1^{\text {st }} \text { Sentence }\end{array}$ & & The description of the conceptual site model presented... & \multicolumn{2}{|c|}{ The text has been added } & Yes \\
\hline
\end{tabular}


NEVADA ENVIRONMENTAL RESTORATION PROJECT

\section{DOCUMENT REVIEW SHEET}

\begin{tabular}{|c|c|c|c|c|}
\hline $\begin{array}{l}\text { 10. Comment } \\
\text { Number/ } \\
\text { Location }\end{array}$ & 11. Type* & 12. Comment & 13. Comment Response & $\begin{array}{l}14 . \\
\text { Accept }\end{array}$ \\
\hline $\begin{array}{l}\text { 4) Section } 3.3 .3, \\
\text { Page } 25 \text { of } 52, \\
\text { Radiological } \\
\text { Preliminary Action } \\
\text { Levels, } 1^{\text {st }} \\
\text { Paragraph }\end{array}$ & & $\begin{array}{l}\text { The Multi-Agency Radiation Survey and Site Investigation Manual } \\
\text { (MARSSIM) has not yet been agreed to by NDEP for use at the } \\
\text { NTS. NDEP cannot concur with this method until DOE establishes } \\
\text { how MARSSIM integrates with other DOE radiological survey } \\
\text { protocols. }\end{array}$ & $\begin{array}{l}\text { Section } 3.3 .3,1^{\text {st }} \text { paragraph, has been changed to read as } \\
\text { follows: } \\
\text { "The PALs for radionuclides are isotope-specific and are } \\
\text { defined as the maximum concentration for that isotope } \\
\text { found in environmental samples taken from undisturbed } \\
\text { background locations. Environmental background } \\
\text { samples previously taken in the vicinity of Area } 3 \text { and } \\
\text { Area } 9 \text { at the TTR (in the vicinity of CAUs } 406 \text { and } 429 \text { ) } \\
\text { will be compared with the results for environmental } \\
\text { samples taken from other undisturbed background } \\
\text { locations on the TTR. In addition, the radionuclide } \\
\text { concentrations in the CAUs } 406 \text { and } 429 \text { and TTR } \\
\text { background samples will be compared with the } \\
\text { radionuclide concentrations found in environmental } \\
\text { samples taken from undisturbed background locations in } \\
\text { the vicinity of the NTS, presented in McArthur and Miller } \\
\text { (1989) and Atlan-Tech (1992). The PAL for each isotope } \\
\text { will be the maximum concentration of that isotope found in } \\
\text { any of the samples taken from the undisturbed } \\
\text { background location described above." }\end{array}$ & Yes \\
\hline $\begin{array}{l}\text { 5) Section } 5.3 .5 \text {, } \\
\text { Page } 46 \text { of } 52 \text {, } \\
\text { Mixed Waste, Last } \\
\text { Paragraph after } \\
\text { First Sentence }\end{array}$ & & NDEP will be notified if any mixed waste is generated. & The text has been added to the end of the last paragraph. & Yes \\
\hline
\end{tabular}

a Comment Types: $M=$ Mandatory, $S=$ Suggested.

Return Document Review Sheets to DOE/NV Environmental Restoration Division, Attn: QAC, M/S 505. 


\section{Distribution}

* Provide copy in distribution of Rev. 0 and subsequent revisions, if applicable.

Copies of the NDEP-approved document will be distributed to others.

Paul J. Liebendorfer

State of Nevada

Bureau of Federal Facilities

Division of Environmental Protection

333 W. Nye Lane, Room 138

Carson City, NV 89706-0851

Michael McKinnon

State of Nevada

Bureau of Federal Facilities

Division of Environmental Protection

555 E. Washington, Suite 4300

Las Vegas, NV 89101

Sabrina Lawrence

Environmental Restoration Division

DOE/Nevada Operations Office

P.O. Box 98518, M/S 505

Las Vegas, NV 89193-8518

Janet Appenzeller-Wing

Environmental Restoration Division

DOE/Nevada Operations Office

P.O. Box 98518, M/S 505

Las Vegas, NV 89193-8518

Kevin Cabble

Environmental Restoration Division

DOE/Nevada Operations Office

P.O. Box 98518, M/S 505

Las Vegas, NV 89193-8518

Shannon Parsons-DePry

Bechtel Nevada

P.O. Box 98521, M/S NTS306

Las Vegas, NV 89193-8521
2 (Controlled)*

1 (Controlled)*

1 (Controlled)*

1 (Uncontrolled)*

1 (Uncontrolled)*

1 (Uncontrolled)* 
Steve Nacht

Bechtel Nevada

P.O. Box 98521, M/S NTS306

Las Vegas, NV 89193-8521

IT Corporation Central Files

P.O. Box 93838

Las Vegas, NV 89193

Dawn Arnold

SAIC

P.O. Box 93838

Las Vegas, NV 89193

Mary Todd

SAIC

P.O. Box 93838

Las Vegas, NV 89193

Technical Information Resource Center

DOE/Nevada Operations Office

P.O. Box 98518, M/S 505

Las Vegas, NV 89193-8518

U.S. Department of Energy

Office of Scientific and Technical Information

P.O. Box 62

Oak Ridge, TN 37831

Manager Southern Nevada FFACO

Public Reading Room

P.O. Box 98521, M/S NLV040

Las Vegas, NV 89193-8521

Manager Northern Nevada FFACO

Public Reading Room

c/o Rosa Silver

IT Corporation

P.O. Box 93838

Las Vegas, NV 89193
1 (Uncontrolled)*

1 (Uncontrolled)*

1 (Controlled)*

1 (Uncontrolled)*

1 (Uncontrolled)

1 (Uncontrolled, electronic copy)

1 (Controlled)

1 (Uncontrolled)

1 (Uncontrolled) 
FFACO Public Reading Room Coordinator

1 (Controlled)

Rosa Silver

IT Corporation

P.O. Box 93838

Las Vegas, NV 89193 